\title{
Energy and Energy Cost Savings Analysis of the IECC for Commercial Buildings
}

$\begin{array}{ll}\text { J Zhang } & \text { Y Xie } \\ \text { R Athalye } & \text { S Goel } \\ \text { R Hart } & \text { V Mendon } \\ \text { M Rosenberg } & \text { B Liu }\end{array}$

August 2013

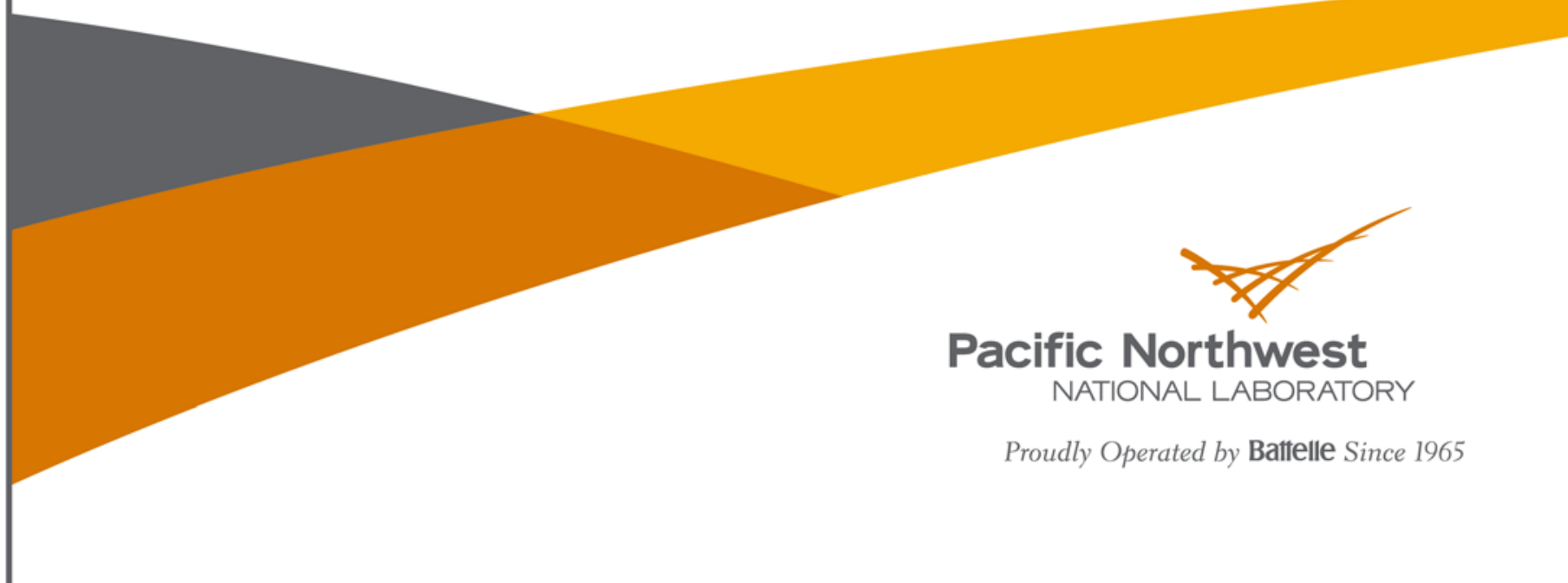




\title{
DISCLAIMER
}

This report was prepared as an account of work sponsored by an agency of the United States Government. Neither the United States Government nor any agency thereof, nor Battelle Memorial Institute, nor any of their employees, makes any warranty, express or implied, or assumes any legal liability or responsibility for the accuracy, completeness, or usefulness of any information, apparatus, product, or process disclosed, or represents that its use would not infringe privately owned rights. Reference herein to any specific commercial product, process, or service by trade name, trademark, manufacturer, or otherwise does not necessarily constitute or imply its endorsement, recommendation, or favoring by the United States Government or any agency thereof, or Battelle Memorial Institute. The views and opinions of authors expressed herein do not necessarily state or reflect those of the United States Government or any agency thereof.

\author{
PACIFIC NORTHWEST NATIONAL LABORATORY \\ operated by \\ BATTELLE \\ for the \\ UNITED STATES DEPARTMENT OF ENERGY \\ under Contract DE-AC05-76RL01830
}

Printed in the United States of America
Available to DOE and DOE contractors from the Office of Scientific and Technical Information,
P.O. Box 62, Oak Ridge, TN 37831-0062;
ph: (865) 576-8401
fax: $(865)$ 576-5728
email: reports@adonis.osti.gov
Available to the public from the National Technical Information Service
5301 Shawnee Rd., Alexandria, VA 22312
ph: (800) 553-NTIS (6847)
email: orders@ntis.gov $<$ http://www.ntis.gov/about/form.aspx >
Online ordering: http://www.ntis.gov

This document was printed on recycled paper. 


\section{Energy and Energy Cost Savings Analysis of the IECC for Commercial Buildings}

$\begin{array}{ll}\text { J Zhang } & \text { Y Xie } \\ \text { R Athalye } & \text { S Goel } \\ \text { R Hart } & \text { V Mendon } \\ \text { M Rosenberg } & \text { B Liu }\end{array}$

August 2013

Prepared for

the U.S. Department of Energy

under Contract DE-AC05-76RL01830

Pacific Northwest National Laboratory

Richland, Washington 99352 


\section{Executive Summary}

This analysis was conducted by Pacific Northwest National Laboratory (PNNL) in support of the U.S. Department of Energy (DOE) Building Energy Codes Program (BECP). DOE supports energy efficiency in buildings through the development and implementation of model codes and standards. DOE also provides technical assistance to states and localities as they adopt and enforce energy codes.

The purpose of this analysis is to assess the relative energy and energy cost performance of commercial buildings designed to meet the requirements found in the commercial energy efficiency provisions of the International Energy Conservation Code (IECC). Section 304(b) of the Energy Conservation and Production Act (ECPA), as amended, requires the Secretary of Energy to make a determination each time a revised version of ASHRAE Standard 90.1 is published with respect to whether the revised standard would improve energy efficiency in commercial buildings. As many states have historically adopted the IECC for both residential and commercial buildings, PNNL has evaluated the impacts of the commercial provisions of the 2006, 2009, and 2012 editions of the IECC. PNNL also compared energy performance with corresponding editions of ANSI/ASHRAE/IES Standard 90.1 (see Appendix A) to help states and local jurisdictions make informed decisions regarding model code adoption. Of the 41 States with commercial building energy codes currently, 29 use a version of the IECC (BECP 2012a).

The present analysis builds on previous work conducted by PNNL to assess the energy performance of the three most recent editions of Standard 90.1. For that effort, PNNL researchers developed a metric and process called the "Progress Indicator" (PI) (Thornton et al. 2011), which uses a suite of 16 prototype buildings (BECP 2012b) representing 80\% of the commercial building floor area for new construction in the United States. The researchers conducted simulations across 17 climate locations using the DOE energy simulation program EnergyPlus ${ }^{\mathrm{TM}}$, and aggregated the results to provide an estimate of the overall national impact of the code across climate zones and building types.

The results of the present analysis are summarized in Table E.1 and detailed in Chapter 4 of this report. As shown in Table ES.1, the Energy Use Intensity (EUI) and Energy Cost Index (ECI) are reduced with each subsequent edition of the IECC. For example, the 2009 IECC results in savings as high as $11.4 \%$ (compared to the 2006 IECC). Results are shown both with and without the inclusion of loads not regulated by the IECC (i.e., plug-and-process loads). Figure ES.1 shows the progression of the EUI by prototype with each edition of the IECC. 


\section{Acknowledgments}

This document was prepared by the Pacific Northwest National Laboratory (PNNL) for the U.S. Department of Energy (DOE) Building Energy Codes Program (BECP). The authors would like to thank Mr. Michael Erbesfeld and Mr. Jeremiah Williams, DOE's past and present Project Lead of the Building Energy Codes Program, for their dedicated support and thoughtful guidance during the project.

The authors would also like to thank contributors to the ASHRAE Standard 90.1 Progress Indicator, who built a great technical foundation for the current Commercial IECC Energy Saving Analysis project. Insightful review comments and information provided by Mark Halverson, Heejin Cho, Weimin Wang, Eric Richman, Hung Ngo, David Winiarski, Jennifer Williamson, and Carolyn Noonan at PNNL are greatly appreciated.

Jian Zhang

Project Manager

Pacific Northwest National Laboratory 


\section{Acronyms and Abbreviations}

AIA

ANSI

ASHRAE

BECP

Btu

CBECS

DCV

DOE

DX

ECI

ECPA

$\mathrm{EF}$

EIA

EISA

EPAct

ERV

EUI

$\mathrm{ft}^{2}$

HVAC

ICC

IECC

IES

IESNA

IMC

kBtu

$\mathrm{kWh}$

LPD

MDP

PI

PNNL

PTAC

SAT

SHGC

SL

SWH

TSD

VAV

WWR
American Institute of Architects

American National Standards Institute

American Society of Heating, Refrigerating and Air-Conditioning Engineers

U.S. Department of Energy, Building Energy Codes Program

British thermal unit

Commercial Buildings Energy Consumption Survey

demand controlled ventilation

U.S. Department of Energy

direct expansion

energy cost index

Energy Conservation and Production Act

energy factor

Energy Information Administration

Energy Independence and Security Act

Energy Policy Act

energy recovery ventilation

energy use intensity

square feet

heating, ventilating, and air conditioning

International Code Council

International Energy Conservation Code

Illuminating Engineering Society

Illuminating Engineering Society of North America

International Mechanical Code

thousand British thermal units

kilowatt-hour

lighting power density

minimum damper position

progress indicator

Pacific Northwest National Laboratory

packaged terminal air conditioner

supply air temperature

solar heat gain coefficient

standby energy loss

service water heating

technical support document

variable air volume

window-to-wall ratio 


\section{Contents}

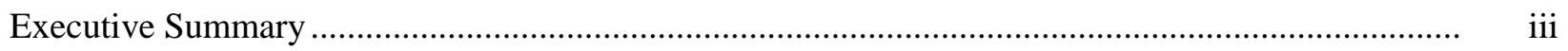

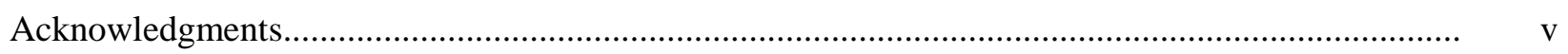

Acronyms and Abbreviations .................................................................................................. vi

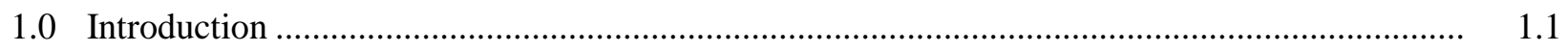

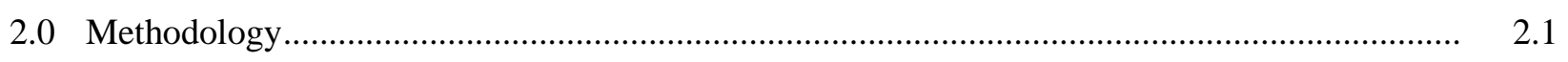

2.1 Basis of Prototype Building Models ............................................................................ 2.1

2.2 Modeling Code Provisions ....................................................................................... 2.2

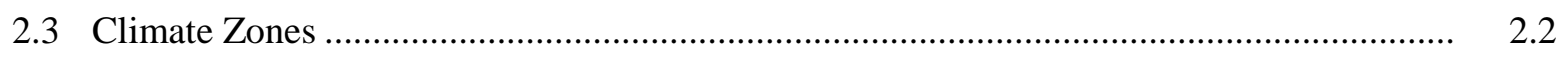

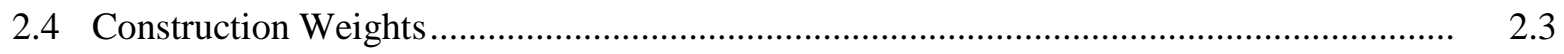

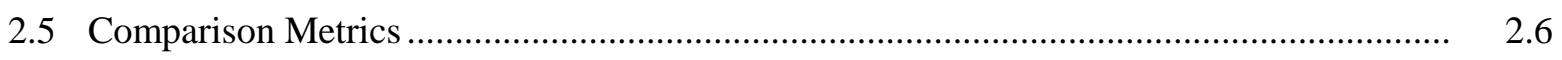

2.6 Model Enhancement............................................................................................. 2.6

3.0 IECC Prototype Model Development............................................................................... 3.1

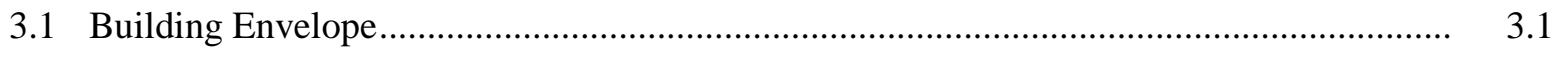

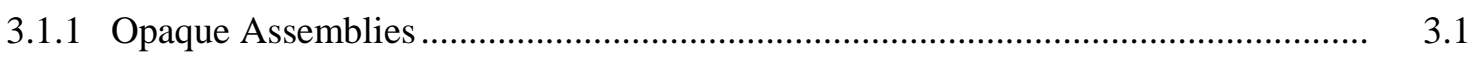

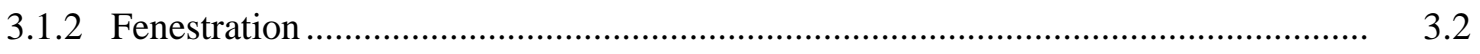

3.1.3 Window-to-Wall Ratio ............................................................................... 3.2

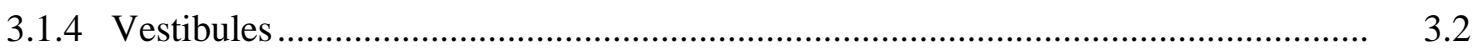

3.1.5 Continuous Air Barrier .................................................................................... 3.3

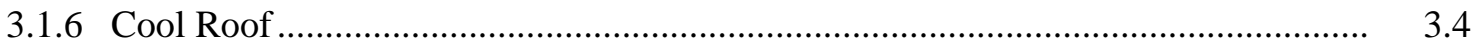

3.2 Building Mechanical Systems ...............................................................................

3.2.1 Heating, Ventilating, and Air-Conditioning Equipment Performance Requirements................................................................................................. 3.6

3.2.2 Optimum Start Control..................................................................................... 3.6

3.2.3 Off-Hour Thermostatic Setback Controls ........................................................ 3.7

3.2.4 Shutoff Damper Controls .............................................................................. 3.7

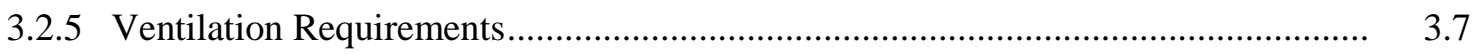

3.2.6 Demand Controlled Ventilation ...................................................................... 3.8

3.2.7 Energy Recovery Ventilation ...................................................................... 3.8

3.2.8 Fan Power Limitation..................................................................................... 3.8

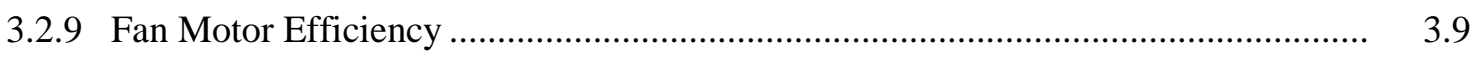

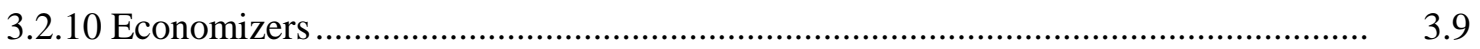

3.2.11 Variable Air Volume Fan Threshold and Control ................................................... 3.10

3.2.12 Multiple-Zone Variable Air Volume System Ventilation ...................................... 3.10

3.2.13 Supply Air Temperature Reset .............................................................................. 3.11

3.3 Service Water Heating ............................................................................................ 3.11

3.4 Electrical Power and Lighting Systems....................................................................... 3.13

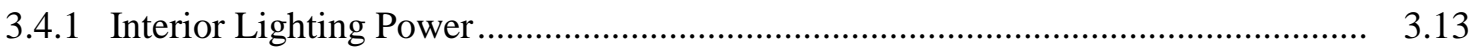


3.4.2 Interior Lighting Control ......................................................................... 3.16

3.4.3 Exterior Lighting Power .......................................................................... 3.17

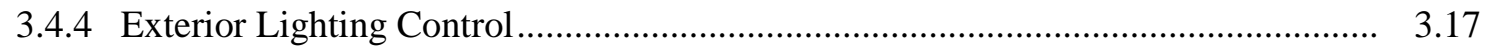

3.4.5 Daylighting (Envelope and Lighting Control) .................................................. 3.18

4.0 IECC Energy Savings and Energy Cost Savings Results ........................................................ 4.1

4.1 Result Comparison between 2006, 2009, and 2012 IECC .............................................. 4.1

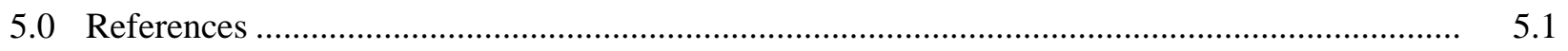

Appendix A - IECC and Referenced Standard 90.1 …........................................................ A.1

Appendix B - Amendments to the 2012 IECC to Align with Standard 90.1-2010 ............................ B.1

Appendix C - Energy Savings Attributable to the IECC and Standard 90.1 by Building Type and

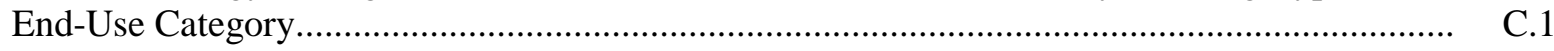

Appendix D - Energy and Energy Cost Comparison for 90.1-2010 and the 2012 IECC by Climate Location and Building Type .................................................................................... D.1 


\section{List of Figures}

ES.1 National Average Energy Use Intensity for all IECC Prototypes ......................................... iv

2.1 Climate Zone Map.......................................................................................................... 2.3

4.1 2009 IECC Site Energy Savings Compared to 2006 IECC with Plug-and-Process Loads......... 4.2

4.22012 IECC Site Energy Savings Compared to 2006 IECC with Plug-and-Process Loads......... 4.2

A.1 Site Energy Savings for the IECC and corresponding Standard 90.1 .................................. A.2

A.2 National Average Energy Use Intensity for all Standard 90.1 and IECC Prototypes with Plug-and-Process Loads ..................................................................................................... A. A

A.3 National Average Energy Use Intensity for all Standard 90.1 and IECC Prototypes without Plug-and-Process Loads. 


\section{List of Tables}

ES.1 Site Energy Savings and Site Energy Cost Savings for the 2009 and 2012 IECC Compared to the 2006 IECC.

2.1 Prototype Buildings Used in the IECC Analysis ................................................................ 2.2

2.2 McGraw Hill Construction Data by Building Type ................................................................ 2.4

2.3 Construction Area Weights by Building Prototype and Climate Subzone................................. 2.5

2.4 National Weighted Average Site EUI Before and After Model Enhancements for Standards 90.1-2004 and -2010....

3.1 2006, 2009, and 2012 IECC Vestibule Requirements

3.2 Infiltration Rate Modeled in IECC Prototype Models

3.3 HVAC Equipment with Efficiency Requirements in Prototype Buildings ...

3.4 Economizer Requirements by Cooling Capacity Thresholds and Climate Subzones...

3.5 Summary of Service Water Heating Equipment in Prototype Buildings

3.6 Whole-Building Lighting Power Densities for Standard 90.1-2004 and Lighting Power Densities and Adjustment Factors for the 2006, 2009, and 2012 IECC .

3.7 Dwelling Unit Lighting Power Density for the 2006, 2009, and 2012 IECC

3.8 Daylight Zone Area as a Fraction of Total Conditioned Floor Area.

3.9 Skylight Area for Warehouse.

4.1 Site Energy Savings and Site Energy Cost Savings for the 2009 and 2012 IECC Compared to the 2006 IECC.

4.2 Site Energy Use Intensity and Savings with Plug-and-Process Loads..................................... 4.3

4.3 Site Energy Cost Index and Energy Cost Savings with Plug-and-Process Loads..................... 4.3

4.4 Site Energy Use Intensity and Savings without Plug-and-Process Loads................................. 4.4

4.5 Site Energy Cost Index and Energy Cost Savings without Plug-and-Process Loads.................. 4.5

A.1 Site Energy Savings and Site Energy Cost Savings for the IECC and corresponding Standard 90.1 (with Plug-and-Process Loads)

A.2 Site Energy Savings and Energy Cost Savings for the 2006 IECC and Standard 90.1-2004 by Prototype (with Plug-and-Process Loads).

A.3 Site Energy Savings and Energy Cost Savings for the 2006 IECC and Standard 90.1-2004 by Climate Zone (with Plug-and-Process Loads) .

A.4 Site Energy Savings and Energy Cost Savings for the 2009 IECC and Standard 90.1-2007 by Prototype (with Plug-and-Process Loads).

A.5 Site Energy Savings and Energy Cost Savings for the 2009 IECC and Standard 90.1-2007 by Climate Zone (with Plug-and-Process Loads)

A.6 Site Energy Savings and Energy Cost Savings for the 2012 IECC and Standard 90.1-2010 by Prototype (with Plug-and-Process Loads)......

A.7 Site Energy Savings and Energy Cost Savings for the 2012 IECC and Standard 90.1-2010 by Climate Zone (with Plug-and-Process Loads) 
A.8 Description of the Key Differences between Standard 90.1-2010 and the 2012 IECC ............. A.7

A.9 Characterization of Key Differences between Standard 90.1-2010 and the 2012 IECC ...

B.1 Site Energy Savings and Energy Cost Savings for the 2012 IECC with Amendments and Standard 90.12010 by Prototype (with Plug-and-Process Loads).

B.2 Site Energy Savings and Energy Cost Savings for the 2012 IECC with Amendments and Standard 90.12010 by Climate Zone (with Plug-and-Process Loads)

C.1 EUI by Prototype and Energy End-Use Category for Standard 90.12004 and the 2006 IECC

C.2 EUI by Prototype and Energy Usage Category for Standard 90.12007 and the 2009 IECC .....

C.3 Energy Use Intensity by Prototype and Energy Usage Category for ASHRAE Standard 90.1 2010 and the 2012 IECC

D.1 Energy and Energy Cost Comparison for the 2012 IECC and 90.1-2010 - Climate Zone 1A Miami

D.2 Energy and Energy Cost Comparison for the 2012 IECC and 90.1-2010 - Climate Zone 2A Houston

D.3 Energy and Energy Cost Comparison for the 2012 IECC and 90.1-2010 - Climate Zone 2B Phoenix

D.4 Energy and Energy Cost Comparison for the 2012 IECC and 90.1-2010 - Climate Zone 3A Memphis.

D.5 Energy and Energy Cost Comparison for the 2012 IECC and 90.1-2010 - Climate Zone 3B El Paso.......

D.6 Energy and Energy Cost Comparison for the 2012 IECC and 90.1-2010 - Climate Zone 3C San Francisco

D.7 Energy and Energy Cost Comparison for the 2012 IECC and 90.1-2010 - Climate Zone 4A Baltimore.

D.8 Energy and Energy Cost Comparison for the 2012 IECC and 90.1-2010 - Climate Zone 4B Albuquerque

D.9 Energy and Energy Cost Comparison for the 2012 IECC and 90.1-2010 - Climate Zone 4C Salem.

D.10 Energy and Energy Cost Comparison for the 2012 IECC and 90.1-2010 - Climate Zone 5A Chicago

D.11 Energy and Energy Cost Comparison for the 2012 IECC and 90.1-2010 - Climate Zone 5B Boise

D.12 Energy and Energy Cost Comparison for the 2012 IECC and 90.1-2010 - Climate Zone 6A Burlington

D.13 Energy and Energy Cost Comparison for the 2012 IECC and 90.1-2010 - Climate Zone 6B Helena

D.14 Energy and Energy Cost Comparison for the 2012 IECC and 90.1-2010 - Climate Zone 7 Duluth.

D.15 Energy and Energy Cost Comparison for the 2012 IECC and 90.1-2010 - Climate Zone 8 Fairbanks 


\subsection{Introduction}

In support of the U.S. Department of Energy (DOE) Building Energy Codes Program (BECP), staff from Pacific Northwest National Laboratory (PNNL) performed an analysis of the relative energy performance of commercial buildings designed to meet the requirements found in the Commercial Energy Efficiency chapters of the 2006, 2009, and 2012 International Energy Conservation Code (IECC) (ICC 2006a, ICC 2009a, 2012a). The purpose of the analysis was to quantitatively evaluate the energy performance of new commercial buildings built to the minimum mandatory and prescriptive requirements of the three respective editions of the IECC. Results of this analysis will help states and local jurisdictions make informed decisions on the energy impacts of different IECC editions when considering adopting a newer edition of the code. This analysis does not consider the impact of these codes on existing building alterations.

During 2010 and 2011, researchers at PNNL conducted building energy simulations of 16 prototype buildings, ${ }^{1}$ representing $80 \%$ of the commercial building floor area for new construction in the United States, to perform a quantitative analysis of Standards 90.1-2004, -2007, and -2010 (Thornton et al. 2011). The current analysis was based on and builds upon the Standard 90.1 work. This analysis considered all mandatory and prescriptive IECC requirements applicable to the prototype buildings, and modeled them using the DOE energy simulation program EnergyPlus ${ }^{\mathrm{TM}}$. The combined impacts of each IECC edition on the suite of 16 prototype buildings in 17 climate locations were considered. This report provides background information about the modeling assumptions and methodology specific to the IECC analysis.

The current report is organized as follows: Section 2.0 summarizes the overall analysis methodology; Section 3.0 describes the modeling strategies for the requirements in the IECC for the categories of building envelope, mechanical systems, service water heating (SWH), and electrical power and lighting systems; Section 4 summarizes the results of the comparison of different versions of the IECC. Appendix A summarizes the IECC analysis results relative to the corresponding Standards 90.1. Appendix B identifies a series of amendments to the 2012 IECC that would align the requirements with Standard 90.12010 to create equivalency on a nationally aggregated basis. Appendix C provides comparisons between Standard 90.1 editions and the corresponding IECC in energy end-use category level for each prototype. Appendix D provides energy and energy cost comparisons between Standard 90.1-2010 and the 2012 IECC by climate location and building type.

\footnotetext{
${ }^{1}$ The simulation models are available online at http://www.energycodes.gov/development/commercial/90.1_models
} 


\subsection{Methodology}

Over the past several years, PNNL researchers expended a substantial effort into developing the prototype models for Standards 90.1-2004, -2007, and -2010. The effort includes developing representative prototype buildings to cover a majority of new commercial constructions, implementing the applicable standard requirements to these prototypes to create compliant simulation models in representative climate locations, and analyzing the simulation results to estimate the energy savings of the standard. The results allow one to compare the national weighted average savings of one standard to its earlier editions. More importantly, PNNL has periodically implemented addenda to Standard 90.1 in the prototype models as they are approved, to measure progress towards the goal of reducing energy use of Standard 90.1-2010 by 30\% compared to Standard 90.1-2004. This research effort including development of the prototypes and quantifying improvements is referred to as the Progress Indicator (PI). In 2011, PNNL published a Technical Support Document (TSD) (Thornton et al 2011) to document the development of the prototype models for Standards 90.1-2004, -2007, and -2010, and the document is hereafter referred to as the PI TSD.

This section summarizes the general methodology developed as part of the PI, which also served as the methodology for this IECC analysis. After the PI TSD was published, PNNL has continued the PI work for the development of Standard 90.1-2013 as well as the IECC prototype development. In order to capture the requirements in the IECC and approved addenda to Standard 90.1-2010, numerous enhancements to the prototype models were made. These enhancements also are described in this section, along with changes in the Standard 90.1 analysis results since they are published in the PI TSD (Thornton et al. 2011).

\subsection{Basis of Prototype Building Models}

As part of the PI analysis, PNNL used a suite of 16 prototype buildings (in EnergyPlus) covering the first 7 principal building activities in the Commercial Buildings Energy Consumption Survey (CBECS; EIA 2003), representing 76\% of the building energy usage of commercial buildings. Of the 16 prototypes, two multifamily prototype buildings (not included in the CBECS) were included in the analysis, because they are regulated by Standard 90.1 and the commercial provisions of IECC: Mid-Rise Apartment and High-Rise Apartment. Table 2.1 shows the 16 prototypes used in this analysis, which represent $80 \%$ of new construction floor area in the U.S. Detailed descriptions of these prototypes are provided in the PI TSD (Thornton et al. 2011). 
Table 2.1. Prototype Buildings Used in the IECC Analysis

\begin{tabular}{ll}
\hline \multicolumn{1}{c}{ Principal Building Activity } & \multicolumn{1}{c}{ Building Prototype } \\
\hline Office & $\begin{array}{l}\text { Small Office } \\
\text { Medium Office } \\
\text { Large Office }\end{array}$ \\
Mercantile & $\begin{array}{l}\text { Stand-Alone Retail } \\
\text { Strip Mall }\end{array}$ \\
Education & $\begin{array}{l}\text { Primary School } \\
\text { Secondary School }\end{array}$ \\
Healthcare & Outpatient Healthcare \\
Lodging & Hospital \\
Warehouse & Small Hotel \\
Food Service & Large Hotel \\
& Warehouse (non-refrigerated) \\
Apartment & Quick-Service Restaurant \\
& Full-Service Restaurant \\
\hline
\end{tabular}

\subsection{Modeling Code Provisions}

The Commercial Energy Efficiency chapter in the 2006, 2009, and 2012 IECC provides three alternative paths for a new building to show compliance: (1) comply with the mandatory and prescriptive requirements in the IECC; (2) comply with the mandatory and total building performance requirements in the IECC; or (3) comply with the requirements in the corresponding Standard 90.1. The focus of this analysis is a comparison of the mandatory and prescriptive requirements of each IECC edition.

The existing Standard 90.1 prototype models provided a foundation for the present analysis, which began with a qualitative comparison of provisions of the 2006 IECC and Standard 90.1-2004. Next, the differences were characterized as either having or not having energy impacts on the prototype buildings. For differences having prototype energy impacts, modeling strategies were developed and applied to the ASHRAE 90.1-2004 prototypes, resulting in prototypes compliant with the 2006 IECC. Following the same approach, another round of characterization was performed to identify differences between the 2009 and 2012 IECC as compared to the 2006 IECC. Those differences were applied to the 2006 IECC prototypes to create the 2009 and 2012 IECC compliant prototypes. This process ensured that all the differences between the successive editions of the IECC were captured. The comparisons were informed by prior work identifying differences between the IECC and its referenced standard. (Conover et al. 2009; Makela et al. 2011)

\subsection{Climate Zones}

The common set of climate zone definitions used by both Standard 90.1 and the IECC includes 8 climate zones (Zones 1 through 8) and 3 moisture regimes (A - moist; B - dry, and C - marine). The combination of climate zone and moisture regime define a climate subzone. The present analysis include 15 climate locations (representing 15 climate subzones covering the entire United States) as shown in 
Figure 2.1 (Briggs et al. 2003) and two non-U.S. climate locations: Riyadh, Saudi Arabia and Vancouver B.C., Canada, representing climate subzones 1B and 5C, respectively.

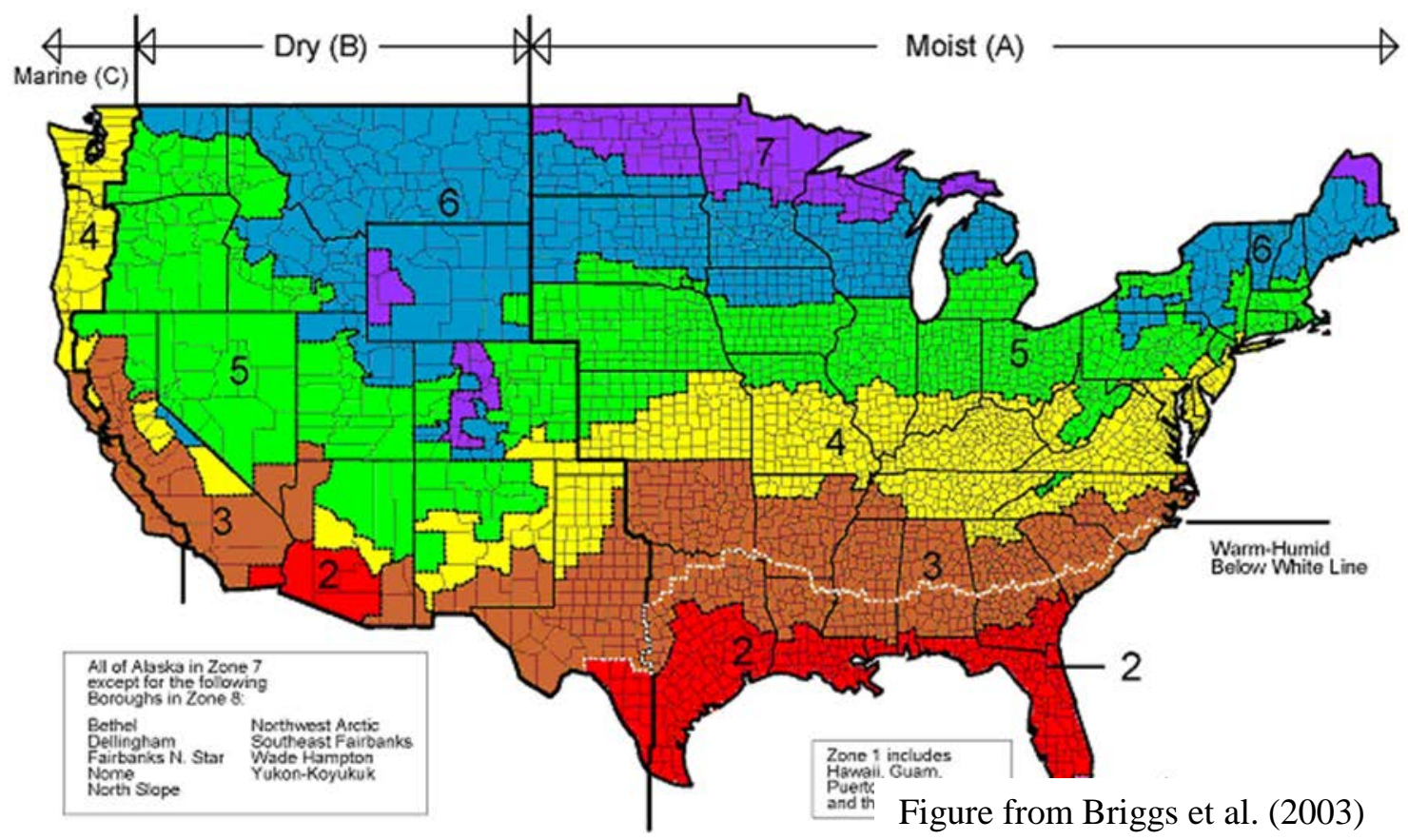

Figure 2.1. Climate Zone Map

The 17 climate locations representing the climate subzones are:

- 1A: Miami, Florida (very hot, humid)

- 1B: Riyadh, Saudi Arabia (very hot, dry)

- 2A: Houston, Texas (hot, humid)

- 2B: Phoenix, Arizona (hot, dry)

- 3A: Memphis, Tennessee (warm, humid)

- 3B: El Paso, Texas (warm, dry)

- 3C: San Francisco, California (warm, marine)

- 4A: Baltimore, Maryland (mixed, humid)

- 4B: Albuquerque, New Mexico (mixed, dry)
- 4C: Salem, Oregon (mixed, marine)

- 5A: Chicago, Illinois (cool, humid)

- 5B: Boise, Idaho (cool, dry)

- 5C: Vancouver B.C., Canada (cool, marine)

- 6A: Burlington, Vermont (cold, humid)

- 6B: Helena, Montana (cold, dry)

- 7: Duluth, Minnesota (very cold)

- 8: Fairbanks, Alaska (subarctic)

\subsection{Construction Weights}

Results of this analysis are weighted by construction volume for each building type and climate subzone in order to calculate the national weighted average Energy Use Intensity (EUI) and Energy Cost Index (ECI). Weighting factors developed by building type and climate-related geographic areas in the 
United States were derived from five years of recent construction data (Jarnagin and Bandyopadhyay 2010). Table 2.2 summarizes the construction floor area and percentage weighting factors by building type. As the table shows, the selected 16 prototypes cover $80 \%$ of new construction floor area. Table 2.3 lists the weighting factors assigned to each prototype in all 15 U.S. climate subzones. The two climate subzones that occur only outside the United States-Riyadh, Saudi Arabia and Vancouver B.C., Canadawere not included in the weighted average. Simulation results for these two subzones only served as references when needing to review modeling strategies and results for individual locations.

Table 2.2. McGraw Hill Construction Data by Building Type (Jarnagin and Bandyopadhyay 2010)

\begin{tabular}{lcr}
\hline \multicolumn{1}{c}{ Prototype } & $\begin{array}{c}\text { Total Floor Area } \\
\left(\times 1,000 \mathrm{ft}^{2}\right)\end{array}$ & $\begin{array}{r}\text { Construction Weights } \\
(\%)\end{array}$ \\
\hline Small Office & 371,009 & 4.5 \\
Medium Office & 400,091 & 4.8 \\
\hline Large Office & 220,134 & 2.7 \\
\hline Stand-Alone Retail & $1,009,246$ & 12.2 \\
\hline Strip Mall & 375,093 & 4.5 \\
\hline Primary School & 330,418 & 4.0 \\
Secondary School & 685,508 & 8.3 \\
Outpatient Healthcare & 289,171 & 3.5 \\
\hline Hospital & 228,131 & 2.8 \\
Small Hotel & 113,837 & 1.4 \\
Large Hotel & 327,562 & 4.0 \\
Warehouse & $1,105,951$ & 13.4 \\
Quick-Service Restaurant & 38,809 & 0.5 \\
Full-Service Restaurant & 43,650 & 0.5 \\
Mid-Rise Apartment & 484,343 & 5.9 \\
\hline High-Rise Apartment & 593,241 & 7.2 \\
Covered by prototypes & $\mathbf{6 , 6 1 6 , 1 9 3}$ & $\mathbf{8 0 . 0}$ \\
No prototype & $\mathbf{1 , 6 4 9 , 7 8 5}$ & $\mathbf{2 0 . 0}$ \\
Total & $\mathbf{8 , 2 6 5 , 9 7 7}$ & $\mathbf{1 0 0 . 0}$ \\
\hline
\end{tabular}


Table 2.3. Construction Area Weights by Building Prototype and Climate Subzone (Jarnagin and Bandyopadhyay 2010)

\begin{tabular}{|c|c|c|c|c|c|c|c|c|c|c|c|c|c|c|c|c|}
\hline & $\begin{array}{l}1 \mathrm{~A} \\
(\%)\end{array}$ & $\begin{array}{l}2 \mathrm{~A} \\
(\%)\end{array}$ & $\begin{array}{l}\text { 2B } \\
(\%)\end{array}$ & $\begin{array}{l}3 \mathrm{~A} \\
(\%)\end{array}$ & $\begin{array}{l}\text { 3B } \\
(\%)\end{array}$ & $\begin{array}{l}3 \mathrm{C} \\
(\%)\end{array}$ & $\begin{array}{l}4 \mathrm{~A} \\
(\%)\end{array}$ & $\begin{array}{l}4 \mathrm{~B} \\
(\%)\end{array}$ & $\begin{array}{l}4 \mathrm{C} \\
(\%)\end{array}$ & $\begin{array}{l}5 \mathrm{~A} \\
(\%)\end{array}$ & $\begin{array}{l}5 \mathrm{~B} \\
(\%)\end{array}$ & $\begin{array}{l}6 \mathrm{~A} \\
(\%)\end{array}$ & $\begin{array}{l}\text { 6B } \\
(\%)\end{array}$ & $\begin{array}{c}7 \\
(\%)\end{array}$ & $\begin{array}{c}8 \\
(\%)\end{array}$ & $\begin{array}{c}\text { Weights } \\
\text { by } \\
\text { Building } \\
\text { Type } \\
\text { (\%) }\end{array}$ \\
\hline Small Office & 0.084 & 1.064 & 0.289 & 0.963 & 0.475 & 0.078 & 0.936 & 0.047 & 0.123 & 0.920 & 0.322 & 0.241 & 0.030 & 0.032 & 0.005 & 5.608 \\
\hline Medium Office & 0.129 & 0.813 & 0.292 & 0.766 & 0.715 & 0.136 & 1.190 & 0.036 & 0.196 & 1.060 & 0.342 & 0.298 & 0.035 & 0.033 & 0.007 & 6.047 \\
\hline Large Office & 0.102 & 0.326 & 0.061 & 0.445 & 0.285 & 0.117 & 1.132 & 0.000 & 0.154 & 0.442 & 0.121 & 0.133 & 0.000 & 0.011 & 0.000 & 3.327 \\
\hline Stand-Alone Retail & 0.224 & 2.220 & 0.507 & 2.386 & 1.250 & 0.191 & 2.545 & 0.119 & 0.428 & 3.429 & 0.792 & 0.948 & 0.091 & 0.109 & 0.014 & 15.254 \\
\hline Strip Mall & 0.137 & 0.991 & 0.254 & 1.021 & 0.626 & 0.103 & 1.008 & 0.023 & 0.107 & 1.023 & 0.201 & 0.153 & 0.016 & 0.007 & 0.001 & 5.669 \\
\hline Primary School & 0.064 & 0.933 & 0.164 & 0.944 & 0.446 & 0.048 & 0.895 & 0.030 & 0.094 & 0.920 & 0.224 & 0.168 & 0.037 & 0.023 & 0.003 & 4.994 \\
\hline Secondary School & 0.160 & 1.523 & 0.230 & 1.893 & 0.819 & 0.109 & 2.013 & 0.063 & 0.243 & 2.282 & 0.438 & 0.415 & 0.086 & 0.075 & 0.012 & 10.361 \\
\hline Outpatient Healthcare & 0.037 & 0.567 & 0.134 & 0.581 & 0.275 & 0.061 & 0.818 & 0.023 & 0.181 & 1.058 & 0.218 & 0.342 & 0.033 & 0.039 & 0.002 & 4.371 \\
\hline Hospital & 0.040 & 0.479 & 0.096 & 0.468 & 0.273 & 0.039 & 0.615 & 0.022 & 0.106 & 0.812 & 0.218 & 0.221 & 0.024 & 0.034 & 0.001 & 3.448 \\
\hline Small Hotel & 0.010 & 0.288 & 0.030 & 0.268 & 0.114 & 0.022 & 0.315 & 0.020 & 0.039 & 0.365 & 0.089 & 0.107 & 0.031 & 0.020 & 0.004 & 1.721 \\
\hline Large Hotel & 0.109 & 0.621 & 0.125 & 0.635 & 0.793 & 0.106 & 0.958 & 0.037 & 0.123 & 0.919 & 0.200 & 0.227 & 0.058 & 0.038 & 0.004 & 4.951 \\
\hline Warehouse & 0.349 & 2.590 & 0.580 & 2.966 & 2.298 & 0.154 & 2.446 & 0.068 & 0.435 & 3.580 & 0.688 & 0.466 & 0.049 & 0.043 & 0.002 & 16.716 \\
\hline Quick-Service Restaurant & 0.008 & 0.092 & 0.020 & 0.102 & 0.063 & 0.007 & 0.089 & 0.005 & 0.014 & 0.128 & 0.026 & 0.025 & 0.003 & 0.004 & 0.000 & 0.587 \\
\hline Full-Service Restaurant & 0.009 & 0.106 & 0.025 & 0.111 & 0.047 & 0.006 & 0.127 & 0.006 & 0.010 & 0.143 & 0.031 & 0.031 & 0.004 & 0.004 & 0.000 & 0.660 \\
\hline Mid-Rise Apartment & 0.257 & 1.094 & 0.093 & 0.825 & 0.862 & 0.260 & 1.694 & 0.022 & 0.371 & 1.122 & 0.318 & 0.313 & 0.056 & 0.032 & 0.000 & 7.321 \\
\hline High-Rise Apartment & 1.521 & 1.512 & 0.076 & 0.652 & 0.741 & 0.173 & 2.506 & 0.000 & 0.358 & 1.163 & 0.115 & 0.125 & 0.016 & 0.008 & 0.000 & 8.967 \\
\hline $\begin{array}{l}\text { Weights by Climate } \\
\text { Subzone }\end{array}$ & 3.242 & 15.217 & 2.975 & 15.025 & 10.081 & 1.609 & 19.286 & 0.522 & 2.981 & 19.366 & 4.344 & 4.214 & 0.569 & 0.513 & 0.056 & 100 \\
\hline
\end{tabular}




\subsection{Comparison Metrics}

During the PI work, researchers at PNNL developed an EnergyPlus simulation infrastructure to allow batch processing for prototype model simulations and results. The primary metrics for comparing different editions of the IECC were the national weighted average site EUI and ECI. The national weighted average EUI - energy use per square foot of conditioned building area per year $\left(\mathrm{kBtu} / \mathrm{ft}^{2} / \mathrm{year}\right)$ represents the energy consumption of all prototype models weighted by construction weight, building type, and climate subzone. The national weighted average ECI - energy cost per square foot of conditioned building area per year $\left(\$ / \mathrm{ft}^{2} /\right.$ year) was computed using a breakdown of energy consumption by utility type (i.e., kWh of electricity and therms of natural gas); no other fuel types are used in the prototype buildings. The national weighted average EUI and ECI was compared between the IECC editions.

PNNL calculated the energy cost savings using national average energy prices from Energy Information Administration (EIA) values. The national average energy prices used in this analysis were $\$ 0.9990 /$ therm for natural gas and $\$ 0.1032 / \mathrm{kWh}$ for electricity (EIA 2011). The same rates were used for all prototypes and in all climate locations.

The IECC and Standard 90.1 do not regulate many plug-and-process loads (e.g., computers, appliances) and other equipment (e.g., gas cooking equipment) in commercial buildings, but they were modeled in the prototype simulations to account for their impact on HVAC systems. The assumptions for the plug-and-process loads are documented in the PI TSD (Thornton et al. 2011). The whole-building energy simulations results are presented (1) with plug-and-process load energy usage to show the impacts on total commercial building energy usage, and (2) without plug-and-process loads to show the impacts on just the regulated energy usage. Results of the analysis are presented in Section 4.0 of this report.

\subsection{Model Enhancement}

PNNL has made numerous enhancements to the original prototype models since they were published in Thornton et al. (2011). The enhancements were made for several reasons, including (1) to change or improve model assumptions at the direction of the ASHRAE Standing Standard Project Committee 90.1; (2) to improve the simulation and simulation infrastructure; and (3) to add additional detail to the model to capture certain energy impacts from Standard 90.1 and the IECC. Major model enhancements included:

- increased window-to-wall ratio (WWR) for Mid-Rise Apartment and High-Rise Apartment prototypes

- added data center to the Large Office prototype

- comprehensively modified SWH assumptions

- introduced outdoor air supply via packaged terminal air conditioners (PTACs) instead of makeup air units in Small Hotel prototype

- improved modeling of ventilation in multiple-zone variable air volume (VAV) systems

- enhanced heat pump controls in Small Office prototype

- revised the retail display lighting adder for the Strip Mall prototype based on standard requirement 
- enhanced optimum start controls (controls that vary the start time of HVAC equipment based on internal loads and weather conditions so that temperature setpoint is just met as building occupancy begins)

- adjusted Warehouse prototype roof reflectance and emmittance

- removed occupancy sensor controls from design day schedules

- accounted for vestibules when required in High-Rise Apartment prototype

- accounted for unintentional heat gain from humidification and pre-heat in Large Office and Hospital prototypes

- improved assumptions for fractional horsepower (hp) motor efficiency

- improved modeling of fan speed and integrated economizer control in direct expansion (DX) units.

Table 2.4 shows the site EUI for Standards 90.1-2004 and -2010 before and after the enhancements were made to the prototype models. The impacts of some enhancements are significant to a few prototypes. The data center added to the Large Office prototype approximately doubled the building EUI. Revised SWH assumptions also increased the EUI for most prototypes.

Table 2.4. National Weighted Average Site EUI Before and After Model Enhancements for Standards 90.1-2004 and -2010

\begin{tabular}{lcccc}
\hline & \multicolumn{2}{c}{ Pre-Enhancements } & \multicolumn{2}{c}{ Post-Enhancements } \\
\cline { 2 - 5 } \multicolumn{1}{c}{ Prototype Name } & $\begin{array}{c}\text { Standard } \\
90.1-2004 \\
\left(\mathrm{kBtu} / \mathrm{ft}^{2} / \mathrm{year}\right)\end{array}$ & $\begin{array}{c}\text { Standard } \\
90.1-2010 \\
\left(\mathrm{kBtu} / \mathrm{ft}^{2} / \text { year }\right)\end{array}$ & $\begin{array}{c}\text { Standard } \\
90.1-2004 \\
\left(\mathrm{kBtu} / \mathrm{ft}^{2} / \text { year }\right)\end{array}$ & $\begin{array}{c}\text { Standard } \\
90.1-2010 \\
\left(\mathrm{kBtu} / \mathrm{ft}^{2} / \text { year }\right)\end{array}$ \\
\hline Small Office & 41.3 & 32.8 & 39.8 & 30.5 \\
Medium Office & 51.6 & 37.3 & 49.4 & 36.0 \\
Large Office & 46.0 & 33.4 & 84.4 & 72.0 \\
Stand-Alone Retail & 76.0 & 49.5 & 77.4 & 52.2 \\
Strip Mall & 80.4 & 56.9 & 80.0 & 56.9 \\
Primary School & 73.4 & 50.2 & 76.7 & 53.9 \\
Secondary School & 66.2 & 41.2 & 66.1 & 46.4 \\
Outpatient Healthcare & 163.3 & 123.6 & 164.6 & 124.2 \\
Hospital & 157.4 & 118.4 & 169.4 & 130.7 \\
Small Hotel & 78.5 & 66.6 & 73.7 & 63.3 \\
Large Hotel & 163.9 & 125.9 & 117.7 & 94.3 \\
Warehouse & 26.3 & 19.0 & 26.9 & 19.5 \\
Quick-Service Restaurant & 570.1 & 519.9 & 640.3 & 592.7 \\
Full-Service Restaurant & 409.7 & 330.9 & 470.0 & 382.7 \\
Mid-Rise Apartment & 47.0 & 41.2 & 51.7 & 45.7 \\
High-Rise Apartment & 48.9 & 44.0 & 58.0 & 52.9 \\
National Weighted Average & $\mathbf{7 3 . 9}$ & $\mathbf{5 5 . 0}$ & $\mathbf{7 5 . 5}$ & $\mathbf{5 8 . 0}$ \\
\hline
\end{tabular}

All of the enhancements were incorporated into the Standard 90.1 prototype models, which became the starting point of the IECC model development. Therefore, the results presented in Section 4.0 of this report represent the comparison between the IECC models and the enhanced Standard 90.1 models. Note: These Standard 90.1 results differ from those published in the PI TSD report (Thornton et al. 2011), because of the enhancements. 


\subsection{IECC Prototype Model Development}

IECC prototype model development builds on the Standard 90.1-2004 prototype models following the model enhancement summarized in Section 2.6. A methodology similar to that used for previous Standard 90.1 analysis was used extensively for this current IECC analysis. As a first step in the analysis process, a qualitative comparison was made between the prescriptive and mandatory requirements of Standard 90.1-2004 and the 2006 IECC. Next, the differences were characterized as either having or not having energy impacts on the prototype buildings. For differences having prototype energy impacts, modeling strategies were developed and applied to the ASHRAE 90.1-2004 prototypes, resulting in prototypes compliant with the 2006 IECC. Following the same approach, another round of characterization was performed to identify differences between the 2009 and 2012 IECC as compared to the 2006 IECC. Those differences were applied to the 2006 IECC prototypes to create the 2009 and 2012 IECC compliant prototypes. This process ensured that all the differences between the successive editions of the IECC were captured.

This section describes the development process and the modeling strategy pertaining to code requirements in the following categories: Section 3.1, building envelope; Section 3.2, building mechanical systems; Section 3.3, SWH; and Section 3, electrical power and lighting systems.

\subsection{Building Envelope}

Section 502 of the 2006 and 2009 IECC and Section C402 of the 2012 IECC specify mandatory and prescriptive requirements for building thermal envelope performance. The differences in these requirements are mainly in six design aspects: opaque assemblies, fenestration, $\mathrm{WWR}$, vestibule, continuous air barrier, and cool roof. The basic construction characteristics (e.g., construction type) applied to the IECC prototype models were consistent with the Standard 90.1 prototype models.

\subsubsection{Opaque Assemblies}

Tables 502.2(1) and 502.2(2) in the 2006 IECC specify opaque envelope component requirements expressed in terms of minimum R-value for roofs, above-grade walls, below-grade walls, floors over outdoor air or unconditioned space, and slab-on-grade floors; and maximum U-factor for opaque doors. These requirements are applicable for all conditioned space categories; there are no distinctions for nonresidential, residential, and semi-heated spaces.

Tables 502.1.2, 502.2(1), and 502.2(2) in the 2009 IECC modify the 2006 IECC requirements by adding a parallel maximum U-factor compliance options for above-ground opaque envelope components, including roofs, above-grade walls, and floors over outdoor air or unconditioned space; C-factor for below-grade walls; and F-factors for slab-on-grade floors. These factors are defined for two distinct space type categories: "Group-R” (residential space types) and “All-Other” (all commercial and semi-heated spaces). The 2012 IECC has similar classifications for opaque assembly components, but increases the stringency for many of them.

For modeling in EnergyPlus, the U-, C-, and F-factors corresponding to construction types and components defined in the prototype buildings (e.g., metal frame wall) were modified to reflect the 
minimum requirements under the 2006, 2009, or 2012 IECC, as appropriate. Because the 2006 IECC only specifies an R-value compliance table, Standard 90.1-2004 Appendix A was used to convert the 2006 IECC R-values to corresponding assembly U-factors.

\subsubsection{Fenestration}

Section 502.3 in the 2006 and 2009 IECC and Section C402.3 in the 2012 IECC have requirements for maximum fenestration U-factor and SHGC, including requirements for glass doors. These requirements are the same for all space categories (nonresidential, residential, and semi-heated spaces). The 2006 and 2009 IECC provide prescriptive requirements for windows based on the fenestration frame construction type for up to a maximum of 40\% WWR for vertical fenestration. The 2006 and 2009 IECC define two types of vertical fenestration frame construction: nonmetal framing and metal framing.

In contrast to the 2006 and 2009 IECC, the 2012 IECC limits WWR to a maximum of $30 \%$ and classifies vertical fenestration as fixed windows, operable windows, or entrance doors, regardless of the frame construction type. Different U-factor requirements are specified for the three classifications, and SHGC requirements are the same for all classifications.

The 2006, 2009, and 2012 IECC provide maximum U-factor and maximum SHGC requirements for skylights, and they limit skylight area to a maximum of $3 \%$ of roof area that is glazed.

The categorization of fenestration in the IECC mimics what is in the corresponding Standard 90.1 edition; only the U-factor and SHGC values required are different. Sections 4.3 and 5.2.1.3 of the PI TSD (Thornton et al. 2011) describe the modeling strategy for fenestration requirements in detail. PNNL researchers followed this same strategy for defining the vertical fenestration and skylight properties for the 2006, 2009, and 2012 IECC.

\subsubsection{Window-to-Wall Ratio}

The IECC differs from Standard 90.1 in its definition of "window-to-wall ratio." The IECC considers only above-grade walls in the calculation of WWR, unlike Standard 90.1, which considers both belowgrade (basement) and above-grade walls in determining WWR. Maximum permitted WWR is $40 \%$ for the 2006 and 2009 IECC, and 30\% for the 2012 IECC. Most prototypes had WWRs of less than 30\% based on definitions from both IECC and Standard 90.1, and therefore were not impacted by the more stringent requirements of the 2012 IECC. However, four prototypes (Primary School, Secondary School, Medium Office, and Large Office) had WWRs between 30\% and 40\% in their 2006 and 2009 IECC models, and their WWRs were reduced to 30\% for the 2012 IECC models.

\subsubsection{Vestibules}

Standard 90.1 prototypes include vestibules only when the requirements differ between the editions of the standard. In the case of the 2006, 2009, and 2012 IECC prototypes, vestibule requirements do not change within the three IECC editions. However, the IECC vestibule requirements do differ from the Standard 90.1 requirements, and therefore have been simulated. 
Section 502.4.7 in the 2006 and 2009 IECC and Section C402.4.7 in the 2012 IECC exempt vestibules for doors that open to a space smaller than 3,000 $\mathrm{ft}^{2}$. Standard 90.1-2004 includes this exception along with a clause that the exempted building should be less than four stories. All three IECC editions and the three Standard 90.1 editions require buildings with four stories or taller to have vestibules. As a result, vestibules were not modeled at all in the Large Office, Large Hotel, and Hospital in either IECC or Standard 90.1, because there were no relative energy impacts to be captured. Table 3.1 shows the vestibule requirements for each prototype in each climate zone for all three IECC editions.

Table 3.1. 2006, 2009, and 2012 IECC Vestibule Requirements

\begin{tabular}{|c|c|c|c|c|c|c|c|c|}
\hline Building Prototype & Zone $1^{\text {(a) }}$ & Zone $2^{\text {(a) }}$ & Zone 3 & Zone 4 & Zone 5 & Zone 6 & Zone 7 & Zone 8 \\
\hline Small Office & No & No & $\mathrm{No}^{(\mathrm{d})}$ & $\mathrm{No}^{(\mathrm{d})}$ & $\mathrm{No}^{(\mathrm{d})}$ & $\mathrm{No}^{(\mathrm{d})}$ & $\mathrm{No}^{(\mathrm{d})}$ & $\mathrm{No}^{(\mathrm{d})}$ \\
\hline Medium Office & No & No & $\mathrm{No}^{(\mathrm{d})}$ & No ${ }^{(d)}$ & No ${ }^{(d)}$ & No ${ }^{(d)}$ & $\mathrm{No}^{(\mathrm{d})}$ & $\mathrm{No}^{(\mathrm{d})}$ \\
\hline Large Office & No & No & Yes $^{(b)}$ & Yes $^{(b)}$ & Yes $^{(b)}$ & Yes $^{(b)}$ & Yes $^{(b)}$ & Yes $^{(b)}$ \\
\hline Stand-Alone Retail & No & No & $\mathrm{Yes}^{(\mathrm{c})}$ & $\mathrm{Yes}^{(\mathrm{c})}$ & Yes $^{(c)}$ & Yes $^{(c)}$ & Yes $^{(c)}$ & Yes $^{(\mathrm{c})}$ \\
\hline Strip Mall & No & No & $\mathrm{Yes}^{(\mathrm{c})}$ & Yes $^{(c)}$ & Yes $^{(c)}$ & Yes $^{(c)}$ & Yes $^{(\mathrm{c})}$ & $\mathrm{Yes}^{(\mathrm{c})}$ \\
\hline Primary School & No & No & $\mathrm{No}^{(\mathrm{d})}$ & $\mathrm{No}^{(\mathrm{d})}$ & $\mathrm{No}^{(\mathrm{d})}$ & $\mathrm{No}^{(\mathrm{d})}$ & $\mathrm{No}^{(\mathrm{d})}$ & $\mathrm{No}^{(\mathrm{d})}$ \\
\hline Secondary School & No & No & $\mathrm{No}^{(\mathrm{d})}$ & $\mathrm{No}^{(\mathrm{d})}$ & $\mathrm{No}^{(\mathrm{d})}$ & $\mathrm{No}^{(\mathrm{d})}$ & $\mathrm{No}^{(\mathrm{d})}$ & $\mathrm{No}^{(\mathrm{d})}$ \\
\hline Outpatient Healthcare & No & No & $\mathrm{No}^{(\mathrm{d})}$ & $\mathrm{No}^{(\mathrm{d})}$ & $\mathrm{No}^{(\mathrm{d})}$ & $\mathrm{No}^{(\mathrm{d})}$ & No ${ }^{(d)}$ & $\mathrm{No}^{(\mathrm{d})}$ \\
\hline Hospital & No & No & Yes $^{(b)}$ & Yes $^{(\mathrm{b})}$ & Yes $^{(\mathrm{b})}$ & Yes $^{(\mathrm{b})}$ & Yes $^{(\mathrm{b})}$ & Yes $^{(\mathrm{b})}$ \\
\hline Small Hotel & No & No & $\mathrm{No}^{(\mathrm{d})}$ & $\mathrm{No}^{(\mathrm{d})}$ & $\mathrm{No}^{(\mathrm{d})}$ & $\mathrm{No}^{(\mathrm{d})}$ & $\mathrm{No}^{(\mathrm{d})}$ & $\mathrm{No}^{(\mathrm{d})}$ \\
\hline Large Hotel & No & No & Yes $^{(\mathrm{b})}$ & $Y_{e s}^{(b)}$ & Yes $^{(b)}$ & Yes $^{(b)}$ & $Y_{e s}^{(b)}$ & Yes $^{(b)}$ \\
\hline Warehouse & No & No & $\mathrm{No}^{(\mathrm{d})}$ & No ${ }^{(d)}$ & $\mathrm{No}^{(\mathrm{d})}$ & No ${ }^{(d)}$ & $\mathrm{No}^{(\mathrm{d})}$ & $\mathrm{No}^{(\mathrm{d})}$ \\
\hline $\begin{array}{l}\text { Quick-Service } \\
\text { Restaurant }\end{array}$ & No & No & $\mathrm{No}^{(\mathrm{d})}$ & $\mathrm{No}^{(\mathrm{d})}$ & $\mathrm{No}^{(\mathrm{d})}$ & $\mathrm{No}^{(\mathrm{d})}$ & No ${ }^{(d)}$ & $\mathrm{No}^{(\mathrm{d})}$ \\
\hline Sit-Down Restaurant & No & No & $\mathrm{No}^{(\mathrm{d})}$ & $\mathrm{No}^{(\mathrm{d})}$ & $\mathrm{No}^{(\mathrm{d})}$ & $\mathrm{No}^{(\mathrm{d})}$ & No ${ }^{(d)}$ & $\mathrm{No}^{(\mathrm{d})}$ \\
\hline Mid-Rise Apartment & No & No & No ${ }^{(d)}$ & No ${ }^{(d)}$ & No ${ }^{(d)}$ & No ${ }^{(d)}$ & No ${ }^{(d)}$ & No ${ }^{(d)}$ \\
\hline High-Rise Apartment & No & No & $\mathrm{No}^{(\mathrm{d})}$ & $\mathrm{No}^{(\mathrm{d})}$ & No ${ }^{(d)}$ & No ${ }^{(d)}$ & $\mathrm{No}^{(\mathrm{d})}$ & $\mathrm{No}^{(\mathrm{d})}$ \\
\hline
\end{tabular}

(a) Exemption for buildings in climate zones 1 and 2.

(b) Required, but not simulated because there is no relative difference between the ASHRAE and IECC prototypes.

(c) Required by the 2012 IECC as door opens to spaces more than 3,000 $\mathrm{ft}^{2}$.

(d) Exemption for doors opening to spaces $3,000 \mathrm{ft}^{2}$ or less.

When the air infiltration rate through a door (with or without a vestibule) is modeled, the rate was calculated for each building using a simplified method. That method considered design wind speed, door area, and building height to a neutral pressure plane (used to estimate the stack effect driven air pressure on the door) of one-half the building height and a multiplication coefficient that is a function of door opening frequency (Cho et al. 2010). The PI TSD (Thornton et al. 2011) summarizes the strategy used to simulate vestibules in the Standard 90.1 prototypes. The same strategy was used to develop the IECC prototype models.

\subsubsection{Continuous Air Barrier}

Section 502.4 of the 2006 and 2009 IECC, mandates air leakage requirements for window and door assemblies, curtain wall, storefront glazing, commercial entrance doors, loading dock weather seals, and 
sealing of the building envelope. Although the requirements (for example fenestration air leakage rate) are slightly different from Standard 90.1-2004, it was decided to use the same air leakage input as the Standard 90.1-2004 prototypes. A whole building infiltration rate of $1.8 \mathrm{cfm} / \mathrm{ft}^{2}$ at 0.3 in. w.c. of exterior above-grade envelope surface area was used, based on the average air tightness levels summarized in a National Institute of Science and Technology report (Emmerich et al. 2005).

Section C402.4 of the 2012 IECC addresses the air leakage requirements as a continuous air barrier is needed throughout the building envelope in other than climate zones 1-3; and three compliance options are provided including (1) materials, (2) assemblies, (3) whole building air leakage test. The first two options are very similar to the two options in Section 5.4.3.1.3 of Standard 90.1-2010. It was decided to use the same air leakage model assumption developed for the Standard 90.1-2010 prototypes for the 2012 IECC prototypes.

Both the IECC and Standard 90.1 have requirements for sealing recessed lighting fixtures that open into unconditioned spaces. These requirements were not modeled for either Standard 90.1 or the IECC because there is no relative energy saving impact to be captured.

Table 3.2 shows the infiltration values for all the prototypes for the three editions of the IECC. The PI TSD (Thornton et al. 2011) summarizes the process for calculating these infiltration rates for both buildings with and without continuous air barriers. The infiltration rates shown in Table 3.2 were used to calculate the infiltration for the different IECC edition models.

Table 3.2. Infiltration Rate Modeled in IECC Prototype Models

\begin{tabular}{lccc}
\hline & $\begin{array}{c}\text { 2006 IECC } \\
\mathrm{cfm} / \mathrm{ft}^{2}\end{array}$ & $\begin{array}{c}\text { 2a) } \\
\mathrm{cfm} / \mathrm{ft}^{2}\end{array}$ & $\begin{array}{c}\text { (a) } \\
\mathrm{cfm} / \mathrm{ft}^{2} \text { (a) }\end{array}$ \\
\hline Climate Zones 1, 2, and 3 & 1.8 & 1.8 & 1.8 \\
Climate Zones 4-8 & 1.8 & 1.8 & 1.0 \\
\hline
\end{tabular}

(a) Infiltration rate in $\mathrm{cfm} / \mathrm{ft}^{2}$ are based on exterior above-grade envelope surface area at 0.3 inch water column

\subsubsection{Cool Roof}

The IECC and Standard 90.1 are similar in their definition of minimum reflectance or emmittance requirements for roofs. Similar to the corresponding Standard 90.1-2004, the 2006 and 2009 IECC do not specify minimum reflectance or emmittance requirements for roofs. Section C402.2.1.1 of the 2012 IECC requires a minimum three-year-aged solar reflectance of 0.55 and a minimum three-year-aged thermal emmittance of 0.75 for roofs in climate zones 1 through 3, which is similar to Standard 90.1-2010. However, the exceptions in Standard 90.1-2010 and the 2012 IECC are slightly different. Standard 90.1-2010 exempts steep-sloped roofs, roofs over semi-heated spaces, and metal roofs from cool roof requirements. This exempts the Small Office, Quick-Service Restaurant, and Full-Service Restaurant prototypes, which have steep slopes, and the Warehouse prototype because the roof is over a semi-heated space. The 2012 IECC does not have exceptions for roofs over semi-heated spaces or metal building roofs, but it does have an exception for steep-sloped roofs. Therefore, the 2012 IECC requires cool roofs for the Warehouse, but exempts cool roofs for the Small Office, Quick-Service Restaurant, and FullService Restaurant prototypes. 
The PI TSD (Thornton et al. 2011) specifies in detail the modeling strategy used to simulate the cool roof requirement for Standard 90.1 prototype models. The same strategy was followed for modeling the cool roof requirement for the IECC prototype models.

\subsection{Building Mechanical Systems}

Section 503.2 of the 2006 and 2009 IECC and Section C403.2 of the 2012 IECC specify mandatory requirements for building mechanical systems; those requirements that potentially have energy impacts on the prototype models are heating, ventilating, and air-conditioning (HVAC) equipment performance; HVAC system control; ventilation; energy recovery; and air system design and control. The IECC prescriptive requirements for building mechanical systems are separately specified for simple HVAC systems (Section 503.3 of the 2006 and 2009 IECC and Section C403.3 of the 2012 IECC) and complex HVAC systems (Section 503.4 of the 2006 and 2009 IECC and Section C403.4 of the 2012 IECC). The differences captured in the IECC prototype models are described in this report based on the energy-saving technology.

Table 3.3 summarizes the equipment included in the IECC prototypes that have mandatory efficiency requirements in the IECC. Unit heaters are not included in this table because the efficiency requirements do not change between the three editions of IECC.

Table 3.3. HVAC Equipment with Efficiency Requirements in Prototype Buildings

\begin{tabular}{|c|c|c|c|c|c|c|c|c|c|c|}
\hline \multirow[b]{2}{*}{ Prototype } & \multicolumn{2}{|c|}{$\begin{array}{c}\text { Unitary Air } \\
\text { Conditioners }\end{array}$} & \multirow{2}{*}{$\begin{array}{c}\text { Air } \\
\text { Source } \\
\text { Heat } \\
\text { Pump }\end{array}$} & \multirow{2}{*}{$\begin{array}{c}\text { Water } \\
\text { to Air } \\
\text { Heat } \\
\text { Pump }\end{array}$} & \multirow[b]{2}{*}{ PTAC } & \multirow{2}{*}{$\begin{array}{l}\text { Water- } \\
\text { Cooled } \\
\text { Chillers }\end{array}$} & \multirow{2}{*}{$\begin{array}{c}\text { Air- } \\
\text { Cooled } \\
\text { Chillers }\end{array}$} & \multirow[b]{2}{*}{ Boiler } & \multirow[b]{2}{*}{ Furnace } & \multirow[b]{2}{*}{$\begin{array}{c}\text { Cooling } \\
\text { Tower }\end{array}$} \\
\hline & $\begin{array}{c}\text { Split } \\
\text { System }\end{array}$ & $\begin{array}{c}\text { Single } \\
\text { Package }\end{array}$ & & & & & & & & \\
\hline Small Office & - & - & Yes & - & - & - & - & - & Yes & - \\
\hline Medium Office & - & Yes & - & - & - & - & - & - & Yes & - \\
\hline Large Office & - & - & - & Yes & - & Yes & - & Yes & - & Yes \\
\hline Stand-Alone Retail & - & Yes & - & - & - & - & - & - & Yes & - \\
\hline Strip Mall & - & Yes & - & - & - & - & - & - & Yes & - \\
\hline Primary School & - & Yes & - & - & - & - & - & Yes & Yes & - \\
\hline Secondary School & - & Yes & - & - & - & - & Yes & Yes & Yes & - \\
\hline Outpatient Healthcare & - & Yes & - & - & - & - & - & Yes & - & - \\
\hline Hospital & - & - & - & - & - & Yes & - & Yes & - & Yes \\
\hline Small Hotel & - & - & - & - & Yes & - & - & - & Yes & - \\
\hline Large Hotel & - & - & - & - & - & - & Yes & Yes & - & - \\
\hline Warehouse & - & Yes & - & - & - & - & - & - & Yes & - \\
\hline Quick-Service Restaurant & - & Yes & - & - & - & - & - & - & Yes & - \\
\hline Full-Service Restaurant & - & Yes & - & - & - & - & - & - & Yes & - \\
\hline Mid-Rise Apartment & Yes & - & - & - & - & - & - & - & Yes & - \\
\hline High-Rise Apartment & - & - & - & Yes & - & - & - & Yes & - & - \\
\hline
\end{tabular}




\subsubsection{Heating, Ventilating, and Air-Conditioning Equipment Performance Requirements}

Section 503.2.3 of the 2006 and 2009 IECC and Section C403.2.3 of the 2012 IECC specify minimum HVAC equipment efficiency as mandatory requirements. HVAC system efficiency requirements depend on the system size, which varies with external climate conditions, internal loads, and outdoor air ventilation rate. Design day simulation is used for HVAC system sizing, and the procedure for defining the system capacity is described in Sections 3.3 and 4.5.2 of the PI TSD (Thornton et al. 2011). Once the equipment types and capacities were determined, proper equipment efficiency inputs were assigned to the EnergyPlus simulation model based on the IECC requirements. Only the efficiency requirements of those HVAC equipment represented in the prototypes has been accounted for in the simulation process, which include:

- unitary air-conditioner efficiency in Table C503.2.3(1) of the 2006 and 2009 IECC, and Table C403.2.3(1) of the 2012 IECC

- air-cooled heat pump efficiency in Table C503.2.3(2) of the 2006 and 2009 IECC, and Table C403.2.3(2) of the 2012 IECC

- water chilling package efficiency in Table C503.2.3(7) of the 2006 and 2009 IECC, and Table C403.2.3(7) of the 2012 IECC

- PTAC and heat pump efficiency in Table C503.2.3(3) of the 2006 and 2009 IECC, and Table C403.2.3(3) of the 2012 IECC

- warm-air furnace efficiency in Table C503.2.3(4) of the 2006 and 2009 IECC, and Table C403.2.3(4) of the 2012 IECC

- boiler efficiency in Table C503.2.3(5) of the 2006 and 2009 IECC, and Table C403.2.3(5) of the 2012 IECC

- heat rejection equipment in Table C503.2.3(11) of the 2006 IECC, and Table C403.2.3(8) of the 2012 IECC (the 2009 IECC does not specific efficiency requirements for heat rejection equipment and they are assumed to be the same as in the 2006 IECC)

\subsubsection{Optimum Start Control}

Section C403.4.3.3 in the 2012 IECC requires optimum start control to be provided for each HVAC system regardless of system size; the 2006 and 2009 IECC do not have similar requirements.

As described in Section 4.1 and Appendix C of the PI TSD (Thornton et al. 2011), most of the prototype buildings had thermostat setback at night, except for some spaces in Mid-Rise Apartment, High-Rise Apartment, Hospital, Small Hotel, and Large Hotel, which are intended to be occupied at night. For those spaces with thermostat setback at night, when optimum start control is not required (the 2006 and 2009 IECC), the occupied thermostat setpoint began two hours before the building is occupied. When optimum start control is required, the occupied thermostat setpoint began when the building is occupied; in addition, a thermostat setpoint two degrees Fahrenheit $\left({ }^{\circ} \mathrm{F}\right)$ higher (for heating) or lower (for cooling) than the night temperature setpoint was applied to the thermostat schedule one hour before the building is occupied. 


\subsubsection{Off-Hour Thermostatic Setback Controls}

Similar to Standards 90.1-2007 and 2010, thermostatic setback control for most conditioned building spaces is required in Section 503.2.4.3 of the 2006 and 2009 IECC, and Section C403.2.4.3 of the 2012 IECC except for in zones that are operated continuously. An exception in Standard 90.1-2004 is provided for HVAC systems serving motel and hotel guestrooms. This exception was not found in the IECC and therefore not modeled in the IECC prototypes.

\subsubsection{Shutoff Damper Controls}

The 2006, 2009, and 2012 IECC have the same mandatory requirements for motorized damper for both outdoor air supply and exhaust ducts, but the exceptions to the requirements are different from the corresponding ASHRAE standards. All the IECC exempt motorized damper requirements if the building is less than three stories in height or is located in climate zones 1, 2, and 3. Section 5.2.2.20 of the PI TSD (Thornton et al. 2011) specifies in detail the modeling strategy used to simulate the motorized damper for Standard 90.1 prototype models. The same strategy was followed for modeling the shutoff damper controls for the IECC prototype models.

\subsubsection{Ventilation Requirements}

System outdoor air ventilation rates can have a significant impact on commercial building energy use. While zone ventilation rate requirements for Standard 90.1 are specified in ANSI/ASHRAE Standard 62.1, the zone ventilation rate requirements of the 2006, 2009, and 2012 IECC are specified by the 2006, 2009, and 2012 International Mechanical Code (IMC), respectively (ICC 2006b, ICC 2009b, 2012b). The system ventilation rate requirements affect the prototype models through both the zone ventilation rate requirement and the calculation methods used to determine system ventilation requirements.

Section 4.5.5 of the PI TSD (Thornton et al. 2011) describes the implementation of system ventilation rates in the Standard 90.1 prototype models. In order to use the zone ventilation rates specified in ASHRAE Standard 62.1, a consistent mapping of the modeled thermal zones to the space types categorized in the ventilation standards was established.

The zone ventilation rate requirements in the 2006, 2009, and 2012 IMC were compared to the corresponding requirements in Standard 62.1(i.e., the 2006 IMC compared to Standard 62.1-1999; the 2009 IMC compared to Standard 62.1-2004; and the 2012 IMC compared to Standard 62.1-2007). The purpose of the comparison was to determine if the zone ventilation rate requirement (cfm/person and/or $\mathrm{cfm} / \mathrm{ft} 2$ ) established for the Standard 90.1 prototype models could be directly used for the IECC prototype models. The comparison indicated that there were no essential differences in the zone ventilation rate requirements between the IMC and their Standard 62.1 counterparts. Therefore, the zone ventilation rate requirement established for the Standard 90.1 prototype models was used for the IECC prototype models. Specifically, zone ventilation requirements of Standard 62.1-1999 were used for the 2006 IECC prototype models, and zone ventilation requirements of Standard 62.1-2004 (same requirements as in Standard 62.1-2007) were used for the 2009 and 2012 IECC prototype models. For some healthcare related zones in the Hospital and Outpatient Healthcare prototypes, zone ventilation rate requirements in 
the 2001 Guidelines for Design and Construction of Health Care Facilities (AIA 2001) were used for the 2006 IECC models; the requirements in the 2006 edition of the Guidelines (AIA 2006) were used for the 2009 and 2012 IECC models.

Design system ventilation airflow for a single-zone system is based on the sum of ventilation rate of each space served by that system. The calculation for design system ventilation rates for multiple-zone VAV systems is described in Section 3.2.12 of this report.

\subsubsection{Demand Controlled Ventilation}

The 2006 IECC does not have a requirement for demand controlled ventilation (DCV). Section 503.2.5.1 of the 2009 IECC specifies a DCV requirement for spaces larger than $500 \mathrm{ft}^{2}$ and with an average occupancy load of 40 people per $1,000 \mathrm{ft}^{2}$ of floor area. Section C403.2.5.1 of the 2012 IECC reduces the thresholds to spaces larger than $500 \mathrm{ft}^{2}$ and with an average occupant load of 25 people per $1000 \mathrm{ft}^{2}$. If a system, under which the zone is required to have DCV, has energy recovery ventilation (ERV), the DCV requirement is exempted according to the 2009 and 2012 IECC.

The methodology for implementing the DCV in the IECC models was the same as that for the Standard 90.1 models. Based on the occupancy load (25 people per $1000 \mathrm{ft}^{2}$ ) in the 2012 IECC, the classroom zones of the Primary School are required to have DCV. However, due to EnergyPlus program limitations in modeling DCV zones under multiple-zone VAV systems, this 2012 IECC DCV requirement for the Primary School classrooms was not simulated.

\subsubsection{Energy Recovery Ventilation}

ERV requirements in the 2006, 2009, and 2012 IECC are very similar to those in corresponding Standard 90.1 editions. According to Section 503.2.6 of the 2006 and 2009 IECC, ERV is required for systems with a fan size larger than 5,000 cfm and the design outdoor airflow fraction greater than $70 \%$ of the system fan size. Section C403.2.6 of the 2012 IECC specifies the energy recovery requirements by climate zones for different outdoor air fractions and design supply fan size thresholds.

The methodology for implementing ERV in the IECC models was the same as that for the Standard 90.1 models. Section 5.2.2.9 of the PI TSD (Thornton et al. 2011) describes the calculation methodology in detail and as such, this description is not included here.

\subsubsection{Fan Power Limitation}

The design HVAC system fan power is limited by the allowable fan horsepower in Section 503.2.10 of the 2009 IECC and Section C403.2.10 of the 2012 IECC. The 2009 and 2012 IECC have the same maximum fan power allowance; however, the 2006 IECC does not have a provision for fan power

allowance. It was assumed that the 2006 IECC prototypes follow the same fan power limitation as the Standard 90.1-2004 prototypes. The implementation of fan power limitation in the prototype models followed the strategy described in the PI TSD (Thornton et al. 2011). 


\subsubsection{Fan Motor Efficiency}

The IECC does not specify the efficiencies for some equipment covered by federal rules, including electric motors. Applicable requirements of the Energy Policy Act of 1992 (EPAct 1992) are used for the 2006 and 2009 IECC models. Section 313 of the Energy Independence and Security Act of 2007 (EISA 2007) mandates that the efficiency of general-purpose motors that are rated at 1.0 horsepower and larger be increased for motors manufactured on or after December 19, 2010. The efficiency requirements specified by EISA (2007) are used for the 2012 IECC prototype models.

\subsubsection{Economizers}

Economizers are required in all three IECC editions if the cooling capacity exceeds a specified threshold. Table 3.4 characterizes the economizer requirements by cooling capacity thresholds and climate subzones for the IECC.

Table 3.4. Economizer Requirements by Cooling Capacity Thresholds and Climate Subzones

\begin{tabular}{llll}
\hline $\begin{array}{c}\text { Cooling Capacity } \\
\text { Threshold (Btu/hr) }\end{array}$ & \multicolumn{1}{c}{$\begin{array}{c}\text { 2006 IECC } \\
\text { (Climate Subzone) }\end{array}$} & $\begin{array}{c}\text { 2009 IECC } \\
\text { (Climate Subzone) }\end{array}$ & $\begin{array}{c}\text { 2012 IECC } \\
\text { (Climate Subzone) }\end{array}$ \\
\hline No requirement & 1A, 1B, 2A, 3A, 4A, 7, & 1A, 1B, 2A, 7, 8 & 1A, 1B \\
$>=33,000$ & & & 2A, 2B, 3A, 3B, 3C, 4A, 4B, \\
& & & 4C, 5A, 5B, 5C, 6A, 6B, 7, 8 \\
$>=54,000$ & 2B, 3B, 3C, 4B, 4C, 5B, 5C, 6B & 2B, 3A, 3B, 3C, 4A, 4B, & \\
& & 4C,5A, 5B, 5C, 6A, 6B & \\
$>=135,000$ & 5A, 6A & & \\
\hline
\end{tabular}

Where allowed by the applicable IECC, differential dry bulb economizer control type is modeled. When this control is not allowed, differential enthalpy control is used. Whenever an economizer is required, motorized outdoor air dampers are used as they are necessary for economizer operation. Motorized damper operation is described in Section 3.2.4 of this report.

According to guidance provided in the 2009 International Energy Conservation Code and Commentary (ICC 2009c), all economizers are required to be integrated in the IECC (i.e., they should be able to operate simultaneously with mechanical cooling).

The PI TSD (Thornton et al. 2011) describes the economizer modeling in EnergyPlus. Modifications to that strategy were implemented to more accurately model economizers for DX units as part of the model enhancements discussed in Section 2.6 of this report. The EnergyPlus Energy Management System feature was used in the modeling to correctly simulate integrated economizers with DX systems. The built-in EnergyPlus algorithm for economizers assumes perfect integration between the economizer and cooling coil. In practice, however, it is difficult to integrate economizer operation with mechanical cooling without lowering the delta $\mathrm{T}$ provided by the cooling coil. This requires the compressor to have more than one stage. The improved strategy calculated the integration of the economizer at every time step based on the outdoor conditions, the space load, and the compressor stage. Thus, the difference between an economizer with two stages of cooling versus one stage can be correctly captured. 


\subsubsection{Variable Air Volume Fan Threshold and Control}

The VAV fan control requirement provided in Section 503.4.2 of the 2006 and 2009 IECC requires that individual VAV fan systems with motors 10 hp or larger will either:

- be driven by a mechanical or electrical variable-speed drive, or

- have other controls or devices so the fan motor demand be no more than $30 \%$ of design wattage at $50 \%$ of design airflow rate when the static pressure setpoint equals one-third of total design static pressure based on manufacturer-certified fan data.

The requirement of the 2012 IECC (Section C403.4.2) reduces the fan motor size thresholds from 10 hp to $7.5 \mathrm{hp}$ and adds one more prescribed option - a vane axial fan with variable pitch blades. This requirement was implemented by applying different fan curves in EnergyPlus inputs based on the fan size. A VAV fan with power higher than the threshold was assumed to be controlled by a variable frequency drive and otherwise via discharge dampers. One of the two VAV fan system part-load curves, representing either a forward curved fan with "good" static pressure reset or a forward curved fan with discharge damper control, was used in the EnergyPlus simulation. The coefficients of fan performance curves can be found in Table 5.14 of PI TSD (Thornton et al. 2011).

\subsubsection{Multiple-Zone Variable Air Volume System Ventilation}

Section 503.2.5 of the 2006 and 2009 IECC and Section C403.2.5 of the 2012 IECC require buildings to meet system outdoor ventilation requirements specified in the corresponding 2006, 2009, and 2012 IMC. Section 3.2.5 in this report describes how zone ventilation rate in $\mathrm{cfm} /$ person and/or $\mathrm{cfm} / \mathrm{ft}^{2}$ were identified.

Six prototype buildings have multiple-zone VAV systems, including Large Office, Medium Office, Primary School, Secondary School, Hospital, and Large Hotel. Section 403.3 of the 2009 and 2012 IMC (referred to by the 2009 and 2012 IECC, respectively) both require multiple-zone ventilation calculations for design system outdoor air rate, and the calculation method is specified essentially the same as in the Section 6.2.5, Appendix A, and Section 6.2.7 of Standard 62.1-2004. Section 403.3 of the 2006 IMC (referred to by the 2006 IECC) does not explicitly describe the system outdoor air rate calculation method but requires minimum outdoor air rate that accounts for spaces having different ventilation rate requirements under multiple-zone systems. It was decided to treat the IMC 2006 the same as Standard 62.1-2004 for multiple-zone calculations because (1) the multiple-zone calculation method in Standard 62.1-2004 meets Section 403.3.3 requirements in the 2006 IMC; (2) the 2006 IMC was published two years after Standard 62.1-2004. It is reasonable for designers to use Standard 62.1-2004 method to meet Section 403.3.3 requirements in the 2006 IMC.

Unlike the three IECC, Standards 90.1 (Section 6.5.2.1) allows VAV zone minimum damper position (MDP) higher than prescriptive maximums if an overall system annual energy usage reduction can be demonstrated. Optimizing these MDPs resulted in significant outdoor airflow reduction in the Standard 90.1 models. The IECC do not have such a provision, therefore the calculation procedure in Sections 6.2.5, Section 6.2.7, and Appendix A of Standard 62.1-2004 was followed for the six IECC prototype buildings; and the MDPs were set to $30 \%$ of the zone design peak supply rate or the peak outdoor air requirement, whichever is greater. This can lead to extremely high system outdoor airflow rates in some systems in the IECC models. 


\subsubsection{Supply Air Temperature Reset}

The 2006 IECC does not require multiple-zone HVAC systems to reset supply air temperature in response to zone loads; therefore, the 2006 IECC prototype models with multiple-zone systems maintained a constant cooling supply air temperature selected to satisfy the peak cooling load. Section 503.4.5.4 of the 2009 IECC and Section C403.4.5.4 of the 2012 IECC added supply air temperature reset requirements for multiple-zone HVAC systems. Similar to the provisions in Standard 90.1-2010, the 2009 and 2012 IECC allow the supply air temperature reset based on either of two alternative strategies: (1) reset based on the representative building loads, or (2) reset based on outdoor air temperature. Standard 90.1-2010 exempt climate subzones 1A, 2A, and 3A from this requirement, but this exemption is not present in the 2009 and 2012 IECC. The implementation method described in Section 5.2.2.18 of the PI TSD (Thornton et al. 2011) was used to simulate the supply air temperature reset in the 2009 and 2012 IECC prototype models.

\subsection{Service Water Heating}

SWH for general hot water usage was included in all prototype models, but some prototypes also included SWH for specific loads (e.g., commercial kitchens and laundry facilities). The simulations combined loads and storage into a single water heater for most prototype models, although loads on an hourly basis may have used separate hourly schedules with the combined hourly load applied to the single water heater. Some prototypes modeled more than one water heater: the Small Hotel prototype separated the laundry and guestroom loads into two separate water heaters; the Strip Mall prototype included one water heater per store; and the Mid-Rise Apartment prototype included one water heater per apartment. Details of the SWH equipment and schedules are presented in Table 4.15 and Appendix C of the PI TSD (Thornton et al. 2011), but some modifications have been made since including:

- using a central gas-fired water heater to replace the small electrical water heater in each guestroom of the Large Hotel

- changing the fuel type from natural gas to electricity in Small Office and Strip Mall

- adding electrical booster water heater in the kitchen for Hospital, Large Hotel, Full-Service Restaurant, and the two schools

- adding/splitting natural gas-fired laundry water heaters for Hospital and the two hotels

- modifying the volumes and capacity of the water heaters

Table 3.5 lists the SWH equipment specified in the prototype models. SWH equipment efficiency is provided in Tables 504.2 of the 2006 and 2009 IECC and Table C404.2 of the 2012 IECC, and remains unchanged in each edition. Although the performance requirement tables cover many categories of equipment, only the following four categories of equipment are applicable to the IECC prototype models:

1. electric water heater $<12 \mathrm{~kW}$ for the main water heaters in Small Office, Retail Strip Mall, and Warehouse, booster water heater in Hospital, Large Hotel, Full-Service Restaurant, and Primary School

2. electric water heater $\geq 12 \mathrm{~kW}$ for the main water heater in Mid-Rise Apartment and booster water heater in Secondary School 
Table 3.5. Summary of Service Water Heating Equipment in Prototype Buildings

\begin{tabular}{|c|c|c|c|c|c|c|c|c|c|c|c|c|}
\hline \multirow[b]{2}{*}{ Prototypes } & \multicolumn{6}{|c|}{ Main Water Heater(s) } & \multicolumn{3}{|c|}{ Kitchen Booster Water Heater(s) } & \multicolumn{3}{|c|}{ Laundry Water Heater(s) } \\
\hline & $\begin{array}{c}\text { No. } \\
\text { Water } \\
\text { Heater }\end{array}$ & $\begin{array}{c}\text { Tank } \\
\text { Volume } \\
\text { (gal) }\end{array}$ & $\begin{array}{l}\text { Capacity } \\
\text { (mmbtu/hr) }\end{array}$ & Fuel Type & $\begin{array}{c}\text { Thermal } \\
\text { Zones No. } \\
\text { Served }\end{array}$ & $\begin{array}{c}\text { No. } \\
\text { pumps }\end{array}$ & $\begin{array}{l}\text { Tank } \\
\text { Volume } \\
\text { (gal) }\end{array}$ & $\begin{array}{c}\text { Capacity } \\
\text { (mmbtu/hr) }\end{array}$ & Fuel Type & $\begin{array}{l}\text { Tank } \\
\text { Volume } \\
\text { (gal) }\end{array}$ & $\begin{array}{c}\text { Capacity } \\
\text { (mmbtu/hr) }\end{array}$ & Fuel Type \\
\hline Small Office & 1 & 40 & 0.040 & Electricity & 1 & 1 & & & & & & \\
\hline Medium Office & 1 & 100 & 0.100 & Natural Gas & 15 & 1 & & & & & & \\
\hline Large Office & 1 & 300 & 0.300 & Natural Gas & 3 & 1 & & & & & & \\
\hline Stand-Alone Retail & 1 & 40 & 0.040 & Natural Gas & 1 & & & & & & & \\
\hline Strip Mall & 7 & 40 & 0.040 & Electricity & 7 & & & & & & & \\
\hline Primary School & 1 & 200 & 0.200 & Natural Gas & 2 & 1 & 6 & 0.020 & Electricity & & & \\
\hline Secondary School & 1 & 600 & 0.600 & Natural Gas & 3 & 1 & 6 & 0.048 & Electricity & & & \\
\hline Outpatient Healthcare & 1 & 200 & 0.200 & Natural Gas & 15 & 1 & & & & & & \\
\hline Hospital & 1 & 600 & 0.600 & Natural Gas & 30 & 1 & 6 & 0.010 & Electricity & 300 & 0.300 & Natural Gas \\
\hline Small Hotel & 1 & 300 & 0.300 & Natural Gas & 77 & 2 & & & & 200 & 0.200 & Natural Gas \\
\hline Large Hotel & 1 & 600 & 0.600 & Natural Gas & 10 & 1 & 6 & 0.027 & Electricity & 300 & 0.300 & Natural Gas \\
\hline Warehouse & 1 & 20 & 0.021 & Electricity & 1 & & & & & & & \\
\hline Quick-Service Restaurant & 1 & 100 & 0.100 & Natural Gas & 1 & 1 & & & & & & \\
\hline Full-Service Restaurant & 1 & 200 & 0.200 & Natural Gas & 1 & 1 & 6 & 0.027 & Electricity & & & \\
\hline Mid-Rise Apartment & 23 & 50 & 0.050 & Electricity & 23 & & & & & & & \\
\hline High-Rise Apartment & 1 & 600 & 0.600 & Natural Gas & 79 & 1 & & & & & & \\
\hline
\end{tabular}


3. residential gas-fired storage water heaters $(<75,000 \mathrm{kBtu} / \mathrm{hr})$ for the main water heater in StandAlone Retail

4. commercial gas-fired storage water heater $(\geq 75,000 \mathrm{kBtu} / \mathrm{hr})$ for all the main water heaters in HighRise Apartment, Hospital, Large Hotel, Small Hotel, Large Office, Medium Office, Outpatient Healthcare, Quick-Service Restaurant, Full-Service Restaurant, Primary School, and Secondary School; and all the laundry water heaters in Hospital, Large Hotel, and Small Hotel.

The equipment efficiencies of the categories are provided either in energy factor (EF) or thermal efficiency (Et) and standby energy loss (SL). In the building energy simulation using EnergyPlus, the equipment efficiencies were modeled through two input parameters: burner efficiency and tank heat loss coefficient. These two parameters are derived from the efficiency quantities (EF or Et and SL) provided in the performance requirement tables of these four categories in the standards.

\subsection{Electrical Power and Lighting Systems}

Section 505 of the 2006 and 2009 IECC and Section C405 of the 2012 IECC specify mandatory and prescriptive requirements for building interior and exterior lighting systems, including lighting power limits and control requirements. Section C406 of the 2012 IECC specifies three additional efficiency package options. One of the options (Section C406.3, "Efficiency Lighting System”) was selected to develop the 2012 IECC prototype models.

\subsubsection{Interior Lighting Power}

Interior lighting power requirements in the IECC are generally based on lighting power density, although the requirements for dwelling units are based lamp efficacy.

\subsubsection{Lighting Power Density}

Section 505.5 of the 2006 IECC provides prescriptive interior lighting power requirements for all building types though the building area table (Table 505.5.2). Section 505.5 of the 2009 IECC maintains the same interior lighting power allowances as the 2006 IECC but adds more exceptions in Section 505.5.1. While these exceptions have an energy impact associated with them, the current prototype building models do not have specific provisions for capturing this impact. For this reason, the interior lighting power allowances for the 2009 IECC were considered equivalent to the 2006 IECC for the scope of this study. Section C406 of the 2012 IECC requires choosing one of three high efficiency options: either (1) a high-efficiency HVAC system, (2) an efficient lighting system, or (3) on-site renewable energy for compliance. For this analysis, option (2) high-efficiency lighting (Section C406.3) was chosen because this option is more likely chosen for most building designs than the option (3) on-site renewable (Section C406.4). Option (1) high-efficiency HVAC system (Section C406.2) was not chosen because this option doesn't allow a comparison of the 2012 IECC with its counterpart ASHRAE 90.1-2010 with their HVAC equipment at the same minimum efficiencies addressed in the National Appliance Energy Conservation Act (NAECA), Energy Policy Act (EPAct), and the Energy Independence and Security Act (EISA). Section C406.3 of the 2012 IECC provides lighting power allowances under the high-efficiency lighting option in Table C406.3. 
Standard 90.1 provides two alternate compliance paths for determining allowed lighting power density: the space-by-space method and the building area method. In the Standard 90.1 models developed by PNNL, the lighting power density (LPD) values were implemented using the Standard 90.1 space-byspace method for all prototypes except the Small, Medium, and Large Office prototypes. For the three office prototype models, the Standard 90.1 general office LPD value from the building area method was used. The following methodology was used to incorporate the information from the Standard 90.1 models as much as possible and still create models that represent the IECC requirements adequately.

- Whole-building average LPDs were calculated for all ASHRAE 90.1 prototypes by area-weighting the space-by-space LPDs. This calculation was not necessary for the three office prototypes, as the general office area LPD was used directly.

- Adjustment factors were calculated for each prototype by dividing the IECC allowed LPD by the Standard 90.1-2004 whole-building average LPD.

- Each Standard 90.1-2004 space-type LPD was multiplied by the adjustment factor to yield a wholebuilding LPD that matched the IECC requirements.

Table 3.6 shows the LPDs for Standard 90.1-2004 and the LPDs and adjustment factors for the 2006, 2009, and 2012 IECC.

Table 3.6. Whole-Building Lighting Power Densities for Standard 90.1-2004 and Lighting Power Densities and Adjustment Factors for the 2006, 2009, and 2012 IECC

\begin{tabular}{|c|c|c|c|c|c|c|c|}
\hline \multirow[b]{2}{*}{ Prototype } & \multirow{2}{*}{$\begin{array}{l}\text { Whole-Building Calculated } \\
\text { LPD for Standard 90.1-2004 }\end{array}$} & \multicolumn{3}{|c|}{ LPDs for IECC } & \multicolumn{3}{|c|}{$\begin{array}{l}\text { Adjustment Factors for } \\
\text { IECC }\end{array}$} \\
\hline & & 2006 & 2009 & 2012 & 2006 & 2009 & 2012 \\
\hline High-Rise Apartment & 0.56 & 0.70 & 0.70 & 0.60 & 1.247 & 1.247 & 1.069 \\
\hline Mid-Rise Apartment & 0.63 & 0.70 & 0.70 & 0.60 & 1.106 & 1.106 & 0.948 \\
\hline Hospital & 1.12 & 1.20 & 1.20 & 1.10 & 1.075 & 1.075 & 0.985 \\
\hline Large Hotel & 0.93 & 1.00 & 1.00 & 0.88 & 1.076 & 1.076 & 0.947 \\
\hline Small Hotel & 0.77 & 1.00 & 1.00 & 0.88 & 1.295 & 1.295 & 1.139 \\
\hline Large Office & 1.00 & 1.00 & 1.00 & 0.90 & 1.000 & 1.000 & 0.900 \\
\hline Medium Office & 1.00 & 1.00 & 1.00 & 0.90 & 1.000 & 1.000 & 0.900 \\
\hline Small Office & 1.00 & 1.00 & 1.00 & 0.90 & 1.000 & 1.000 & 0.900 \\
\hline Outpatient Healthcare & 1.09 & 1.00 & 1.00 & 0.87 & 0.914 & 0.914 & 0.795 \\
\hline Quick-Service Restaurant & 1.65 & 1.40 & 1.40 & 0.90 & 0.848 & 0.848 & 0.545 \\
\hline Full-Service Restaurant & 1.85 & 1.60 & 1.60 & 0.89 & 0.863 & 0.863 & 0.480 \\
\hline Stand-Alone Retail & 1.55 & 1.50 & 1.50 & 1.40 & 0.969 & 0.969 & 0.904 \\
\hline Strip Mall & 1.30 & 1.50 & 1.50 & 1.30 & 1.154 & 1.154 & 1.000 \\
\hline Primary School & 1.19 & 1.20 & 1.20 & 0.99 & 1.011 & 1.011 & 0.834 \\
\hline Secondary School & 1.13 & 1.20 & 1.20 & 0.99 & 1.058 & 1.058 & 0.873 \\
\hline Warehouse & 0.81 & 0.80 & 0.80 & 0.60 & 0.988 & 0.988 & 0.741 \\
\hline
\end{tabular}




\subsubsection{Additional Lighting Power Allowance for Retail Display Lighting}

Footnote $b$ to Table 505.5.2 of the 2006 IECC specifies an additional lighting power allowance for retail display lighting. This allowance is the same as Standard 90.1-2004. Footnote b to Table 505.5.2 in the 2009 IECC revises this additional lighting power allowance. The 2009 IECC allowance is the same as Standard 90.1-2007. The high-efficiency lighting path in the 2012 IECC does not allow for additional display lighting allowance.

The methodology for implementing the additional display lighting allowance in the 2006 and 2009 IECC models was the same as that for the Standard 90.1 models. Section 5.2.4.6 of the PI TSD (Thornton et al. 2011) describes the calculation methodology in detail. Therefore, this description is not included here.

\subsubsection{Dwelling Unit Lighting Power Density}

The 2009 IECC requires at least 50\% of all permanently installed luminaires in dwelling units to be high efficacy. The 2012 IECC increases this requirement to $75 \%$ high efficacy. High efficacy is defined by the IECC as compact fluorescent lamps, T-8 or smaller diameter linear fluorescent lamps, or other lamps with a minimum efficacy of: 60 lumens per watt for lamps over 40 watts, 50 lumens per watt for lamps over 15 watts to 40 watts, 40 lumens per watt for lamps 15 watts or less.

Since Standard 90.1 does not regulate lighting in dwelling units, the LPD for dwelling units in the two apartment prototypes for the Standard 90.1 models was calculated from the Building America Research Benchmark Definition (Hendron 2008) at $0.36 \mathrm{~W} / \mathrm{ft}^{2}$. This baseline is treated the same in the 2006 IECC and assumes that $86 \%$ of all lamps are incandescent (low efficacy) and the remaining $14 \%$ are fluorescent (high efficacy). Dwelling unit LPDs for the 2009 and 2012 IECC cases were determined by recalculating annual hard-wired lighting energy using 50\% and 75\% fluorescent fractions respectively using Equations 3.1 and 3.2 from Hendron (2008).

Annual hard-wired indoor lighting $\mathrm{kWh}=(455+0.8 \times \mathrm{CFA}) \times 0.8$

Prototype hard-wired lighting $(\mathrm{kWh} /$ year $)=$ Annual hard-wired lighting $\times$

$$
(1.12 \times \mathrm{FI}+0.279 \times \mathrm{FF})
$$

where

CFA $=$ conditioned floor area $\left(950 \mathrm{ft}^{2}\right.$ for the High-Rise and Mid-Rise Apartment prototypes)

FI = fraction of incandescent lamps ( 0.86 for the 2006 IECC, 0.5 for the 2009 IECC, and 0.25 for the 2012 IECC)

$\mathrm{FF}=$ fraction of fluorescent lamps (0.14 for the 2006 IECC, 0.5 for the 2009 IECC, and 0.75 for the 2012 IECC).

The ratio of the prototype hard-wired lighting ( $\mathrm{kWh} /$ year) from each subsequent version of the standard to the prior version is multiplied by the LPD of the prior version to come up with the new LPD. Table 3.7 shows the LPDs for the dwelling units used for the 2006, 2009, and 2012 IECC. 
Table 3.7. Dwelling Unit Lighting Power Density for the 2006, 2009, and 2012 IECC

\begin{tabular}{cc}
\hline Code & $\begin{array}{c}\text { Dwelling Unit Hard-Wired } \\
\text { Lighting Power Density } \\
\left(\mathrm{W} / \mathrm{ft}^{2}\right)\end{array}$ \\
\hline 2006 IECC & 0.360 \\
2009 IECC & 0.250 \\
2012 IECC & 0.180 \\
\hline
\end{tabular}

\subsubsection{Interior Lighting Control}

There are various types of interior lighting control requirements in the IECC. The 2006 and 2009 IECC require lighting reduction controls that allow occupants to manually reduce the lighting load by at least 50\%, automatic lighting shutoff in buildings larger than 5,000 $\mathrm{ft}^{2}$, occupant override devices where automatic switching devices are provided, and holiday scheduling and master switches in sleeping units in hotels and motels that control all permanently wired receptacles. Most of these requirements are similar to Standard 90.1-2004. Some differences (e.g., the bi-level controls required by the 2006 IECC) exist, but it is difficult to model the human behavior aspect of these provisions and hence, the energy impacts from these provisions were not captured in this study.

The 2012 IECC requires occupancy sensors in classrooms, conference/meeting rooms, employee lunch and break rooms, private offices, restrooms, storage rooms, janitorial closets, and other areas less than $300 \mathrm{ft}^{2}$ enclosed by floor-to-ceiling partitions. The control devices need to turn the lights off within 30 minutes of the occupants leaving the space and can be either manually turned on or automatically controlled to turn the lighting on to no more than $50 \%$ power. Full automatic on controls are allowed in some specified areas. This requirement is very similar to the Standard 90.1-2010 requirement with some exceptions. The 2012 IECC requires occupancy sensors in all enclosed areas less than $300 \mathrm{ft}^{2}$, while Standard 90.1-2010 does not include this provision explicitly, but adds requirements for occupancy sensors in copy rooms, printing rooms, dressing rooms, and fitting rooms. PNNL assumed that most enclosed space types less than $300 \mathrm{ft}^{2}$ are included in the Standard 90.1 requirements and these minor differences result in little or no functional difference and therefore were not modeled. On the other hand, Standard 90.1-2010 requires bathroom lighting control in hotel/motel guestrooms and stairwell lighting control. This difference was captured in the analysis.

The savings from occupancy sensors was calculated using a methodology similar to the one described in Section 5.2.4 of the PI TSD (Thornton et al. 2011). However, the savings was applied to the occupied hours of the zone lighting schedule instead of the zone LPD. An outline of the procedure for determining savings from occupancy sensors is as follows.

- Appropriate building areas that fall into the 2012 IECC occupancy sensor requirements were identified.

- In prototypes like the Small, Medium, and Large Offices and Stand-Alone Retail, where detailed zoning is unavailable, appropriate building areas were determined using the National Commercial 
Construction Characteristics ( $\mathrm{NC}^{3}$ ) database (Richman 2008). ${ }^{2}$ The $\mathrm{NC}^{3}$ database provides a compilation of the Standard 90.1 prototype buildings and the proportion of common building areas.

- Percent lighting energy reduction due to occupancy sensors were determined for all qualifying areas using the same methodology as used in Standard 90.1-2010 as explained in Section 5.2.4.3 of the PI TSD.

- This percentage reduction was applied to the occupied hour values of the lighting schedule used by the specific zone.

- Where a separate zone does not exist in the model for a particular space, the reduction factor was calculated as a product of (1) space area as a fraction of whole-building area from the $\mathrm{NC}^{3}$ database, and (2) target lighting energy savings percentage. This reduction was similarly applied to the occupied hours of the whole-building lighting schedule.

The starting point of the commercial IECC models was the Standard 90.1 models. Standard 90.1-2004 requires occupancy sensors in conference rooms, classrooms, and employee lunchrooms. The lighting schedules for these spaces are assumed to already contain savings from occupancy sensors. The 2006 and 2009 IECC do not have any requirements for occupancy sensors. To account for this, the Standard 90.12004 lighting schedule values are increased by a value equal to the calculated savings from occupancy sensors in the conference rooms, classrooms, and employee lunchrooms.

\subsubsection{Exterior Lighting Power}

Section 505.6.2 of the 2006 IECC specifies exterior lighting allowances equivalent to Standard 90.12004 Section 9.4.5 allowances. The 2009 IECC modified the additional exterior lighting allowance from $5 \%$ in the 2006 IECC to an expanded table of individual lighting allowances for different areas (Table 505.6.2(2)) in addition to the exterior LPD table (Table 505.6.2). Because IECC Section 505.6.2 only references Table 505.6.2(2), the requirements from that table were modeled in this study. Exterior lighting requirements for the 2012 IECC specified in Section C405.6.2 are the same as those in Section 505.6.2 of the 2009 IECC.

The implementation of exterior lighting allowances for the 2006 IECC is the same as 90.1-2004 because the requirements are the same. The exterior power allowances for the 2009 and 2012 IECC's are the same as Standard 90.1-2010. These implementation strategies are discussed in detail in Sections 4.7.2 and 5.2.4.2 of the PI TSD (Thornton et al. 2011) and are not included here.

\subsubsection{Exterior Lighting Control}

Section 505.2.4 of the 2006 IECC requires lighting for all exterior applications to have automatic controls capable of turning off exterior lighting when sufficient daylight is present or when lighting is not required during nighttime hours. It also requires lighting not designated for dusk-to-dawn operation to be controlled by an astronomical time switch, and lighting designated for dusk-to-dawn operation to be controlled by an astronomical time switch or a photosensor. These requirements are identical to Standard 90.1-2004 as specified in Section 9.4.1.3.

\footnotetext{
${ }^{2}$ National Commercial Construction Characteristics Database $\left(\mathrm{NC}^{3}\right)$, an internal PNNL database of nationwide commercial construction energy-related characteristics.
} 
The 2009 IECC modified this Section 505.2.4 requirement to require all exterior lighting to be controlled by either a combination of a photosensor and a time switch or an astronomical time switch. This change does not make any functional change to the requirements and for the purpose of this study; the 2009 IECC requirements for this section are considered the same as the 2006 IECC requirements. Section C405.2.4 of the 2012 IECC is identical to Section 505.2.4 of the 2009 IECC.

The implementation of exterior lighting controls for the 2006, 2009, and 2012 IECC is the same as Standard 90.1-2004 because the requirements are the same. Thus, the exterior lighting schedules for all IECC prototype building models were kept the same as those for the Standard 90.1-2004 models.

\subsubsection{Daylighting (Envelope and Lighting Control)}

Daylighting requirements for the 2006 IECC are similar to Standard 90.1-2004 for the most part. The 2006 and 2009 IECC require general lighting in daylight zones to be controlled separately, but they do not require automatic daylighting controls. As a result, no savings are taken from these two standards for daylighting.

Section C402.3.2 of the 2012 IECC requires a minimum skylight area in spaces larger than 10,000 $\mathrm{ft}^{2}$ and requires multilevel automatic controls in daylight zones from skylights; however, the section does not require multilevel automatic controls for spaces with sidelighting. Only manual controls are required to control general lighting in spaces with sidelit daylight zones. The Primary School and Secondary School prototypes have skylights in the gymnasium zones; however, the Primary School gymnasium zone is smaller than 10,000 $\mathrm{ft}^{2}$ and does not need to comply with this requirement. The Secondary School prototype required multilevel daylighting controls. No sidelighting control requirements were triggered.

The high-efficiency lighting path in the 2012 IECC contains interior lighting power allowances in Section C406.4. The section allows a higher LPD to be used in offices and retail spaces if daylight zones comprise more than $30 \%$ of the total conditioned floor area in the building. It also requires that the daylight zone be controlled by automatic controls. The Stand-Alone Retail, Small Office, and Medium Office prototypes have daylight zones comprising $30 \%$ or more of the total conditioned floor area in the building as shown in Table 3.8. Automatic daylight controls were modeled for these areas.

Table 3.8. Daylight Zone Area as a Fraction of Total Conditioned Floor Area

\begin{tabular}{lccc}
\hline Daylight Zone & $\begin{array}{c}\text { Daylight Area } \\
\left(\mathrm{ft}^{2}\right)\end{array}$ & $\begin{array}{c}\text { Total Conditioned Area } \\
\left(\mathrm{ft}^{2}\right)\end{array}$ & $\begin{array}{c}\text { Daylight Area / } \\
\text { Conditioned Area } \\
(\%)\end{array}$ \\
\hline $\begin{array}{l}\text { Retail Stand-Alone } \\
\text { Core Retail }\end{array}$ & 8,614 & 24,692 & 35 \\
$\begin{array}{c}\text { Small Office } \\
\quad \text { Perimeter Zones }\end{array}$ & 3,642 & 5,502 & 66 \\
$\begin{array}{c}\text { Medium Office } \\
\text { Perimeter Zones }\end{array}$ & 21,870 & 53,628 & 41 \\
\hline
\end{tabular}


Section C406.4 also specifies that warehouses are required to have more than $70 \%$ of the floor area in the daylight zone with automatic controls. This requirement necessitated adding more skylights to the Warehouse prototype model. Table 3.9 provides details of skylight area and number of skylights required in the Warehouse model to meet this requirement.

Table 3.9. Skylight Area for Warehouse

\begin{tabular}{ccccc}
\hline Daylight Zone & $\begin{array}{c}\text { Total Area } \\
\left(\mathrm{ft}^{2}\right)\end{array}$ & $\begin{array}{c}\text { Daylight Area } \\
\text { Required } \\
\left(\mathrm{ft}^{2}\right)\end{array}$ & $\begin{array}{c}\text { Minimum Skylight } \\
\text { Area } \\
\left(\mathrm{ft}^{2}\right)\end{array}$ & Number of Skylights \\
\hline Warehouse & 49,495 & 34,647 & & \\
Bulk Storage & 34,496 & 25,459 & 764 & 48 \\
Fine Storage & 12,448 & 9,187 & 276 & 17 \\
\hline
\end{tabular}

In summary, the Small Office, Medium Office, Stand-Alone Retail and Warehouse prototypes required automatic controls for general lighting in daylight zones, similar to those implemented in ASHRAE 90.1-2010, as described in Section 5.2.4.1 of the PI TSD. The Secondary School prototype has multi-level controls, which require only one step of control below $35 \%$ of full output. 


\subsection{IECC Energy Savings and Energy Cost Savings Results}

This section provides the results of the quantitative savings analysis-the estimated site energy and energy cost savings for the 2009 and 2012 IECC compared to the 2006 IECC. Table 4.1 shows the national aggregated results using the construction weighting factors (see Table 2.3 in this report). Site energy is utility electricity and natural gas delivered and used at the building site. Energy cost savings were based on the site energy usage results and national average costs of electricity and natural gas (see Section 2.5 in this report).

As shown in Table 4.1, the Energy Use Intensity (EUI) and Energy Cost Index (ECI) are reduced with each subsequent edition of the IECC. For example, the 2009 IECC results in savings as high as $11.4 \%$ when compared to the 2006 IECC. Results are shown both with and without including loads not regulated by the IECC (i.e., plug-and-process loads).

Table 4.1. Site Energy Savings and Site Energy Cost Savings for the 2009 and 2012 IECC Compared to the 2006 IECC

\begin{tabular}{|c|c|c|c|}
\hline & 2006 IECC & 2009 IECC & 2012 IECC \\
\hline \multicolumn{4}{|c|}{ With Plug-and-Process Loads (All Loads) } \\
\hline EUI (kBtu/ft²/year) & 76.3 & 69.7 & 62.1 \\
\hline EUI savings compared to 2006 IECC & N/A & $8.7 \%$ & $18.6 \%$ \\
\hline ECI $\left(\$ / \mathrm{ft}^{2} /\right.$ year $)$ & 1.87 & 1.72 & 1.54 \\
\hline ECI savings compared to 2006 IECC & N/A & $7.7 \%$ & $17.4 \%$ \\
\hline \multicolumn{4}{|c|}{ Without Plug-and-Process Loads (Regulated Loads) } \\
\hline EUI (kBtu/ $/ \mathrm{ft}^{2} /$ year $)$ & 57.9 & 51.3 & 43.8 \\
\hline EUI savings compared to 2006 IECC & N/A & $11.4 \%$ & $24.3 \%$ \\
\hline ECI (\$/ft²/year) & 1.45 & 1.30 & 1.13 \\
\hline ECI savings compared to 2006 IECC & N/A & $9.9 \%$ & $22.4 \%$ \\
\hline $\begin{array}{l}\text { EUI }=\quad \text { Energy use intensity } \\
\text { ECI }=\text { Energy cost index } \\
\text { Data in this table are based on a nation }\end{array}$ & ghted avera & & \\
\hline
\end{tabular}

\subsection{Result Comparison between 2006, 2009, and 2012 IECC}

Figure 4.1 and Figure 4.2 show the EUI and EUI savings by prototype for the 2009 and 2012 IECC respectively as compared with the 2006 IECC (with plug-and-process loads). For each prototype, Table 4.2 lists the site EUI and energy savings (with plug-and-process loads) for the 2009 IECC and the 2012 IECC as compared to the 2006 IECC. Table 4.3 lists the site energy costs and energy cost savings, (with plug-and-process loads) for the 2009 IECC and the 2012 IECC as compared to the 2006 IECC. On a weighted national basis, the 2009 IECC results in 8.7\% energy savings over the 2006 IECC, and the 2012 IECC results in $18.6 \%$ energy savings over the 2006 IECC. 


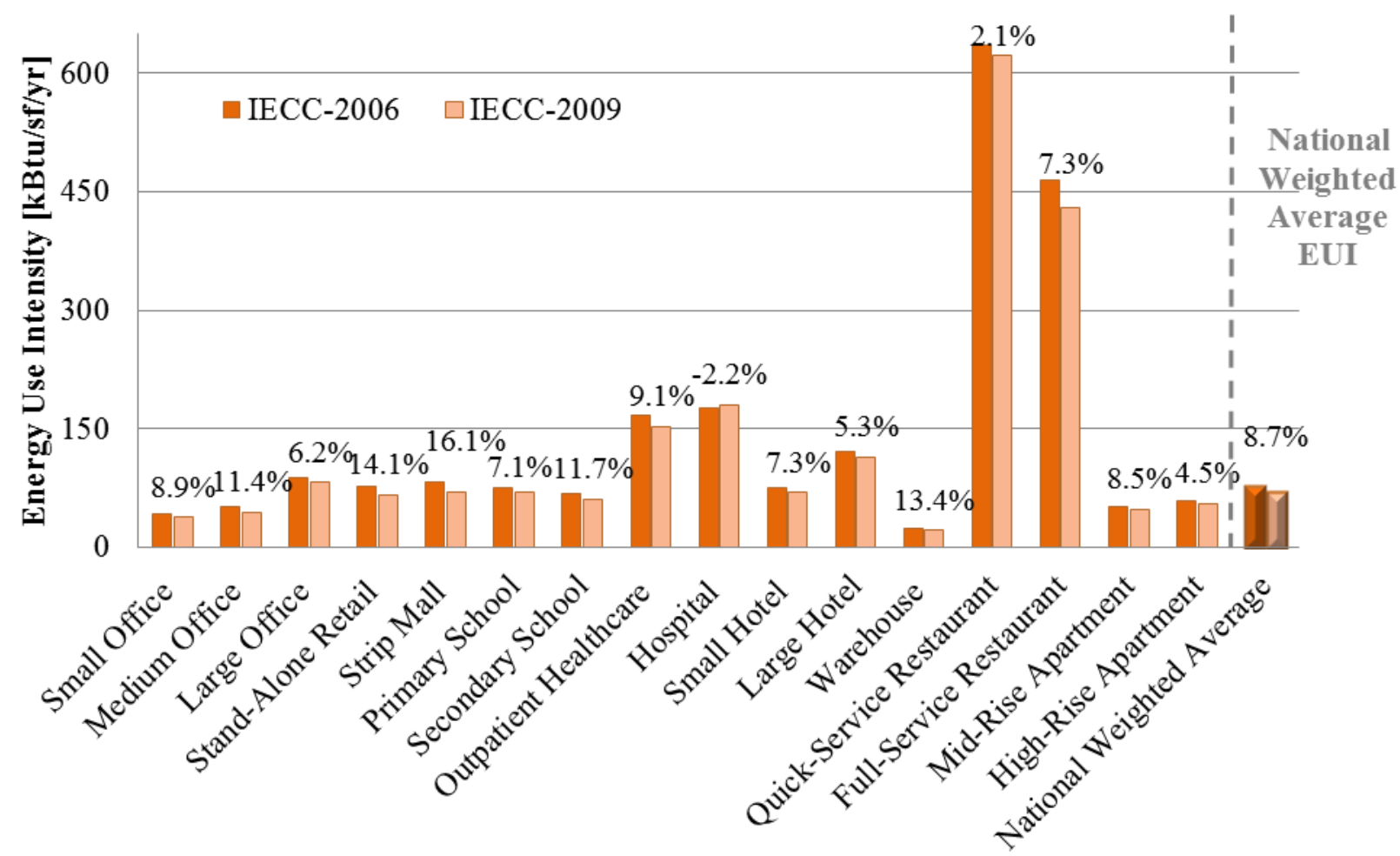

Figure 4.1. 2009 IECC Site Energy Savings Compared to 2006 IECC with Plug-and-Process Loads

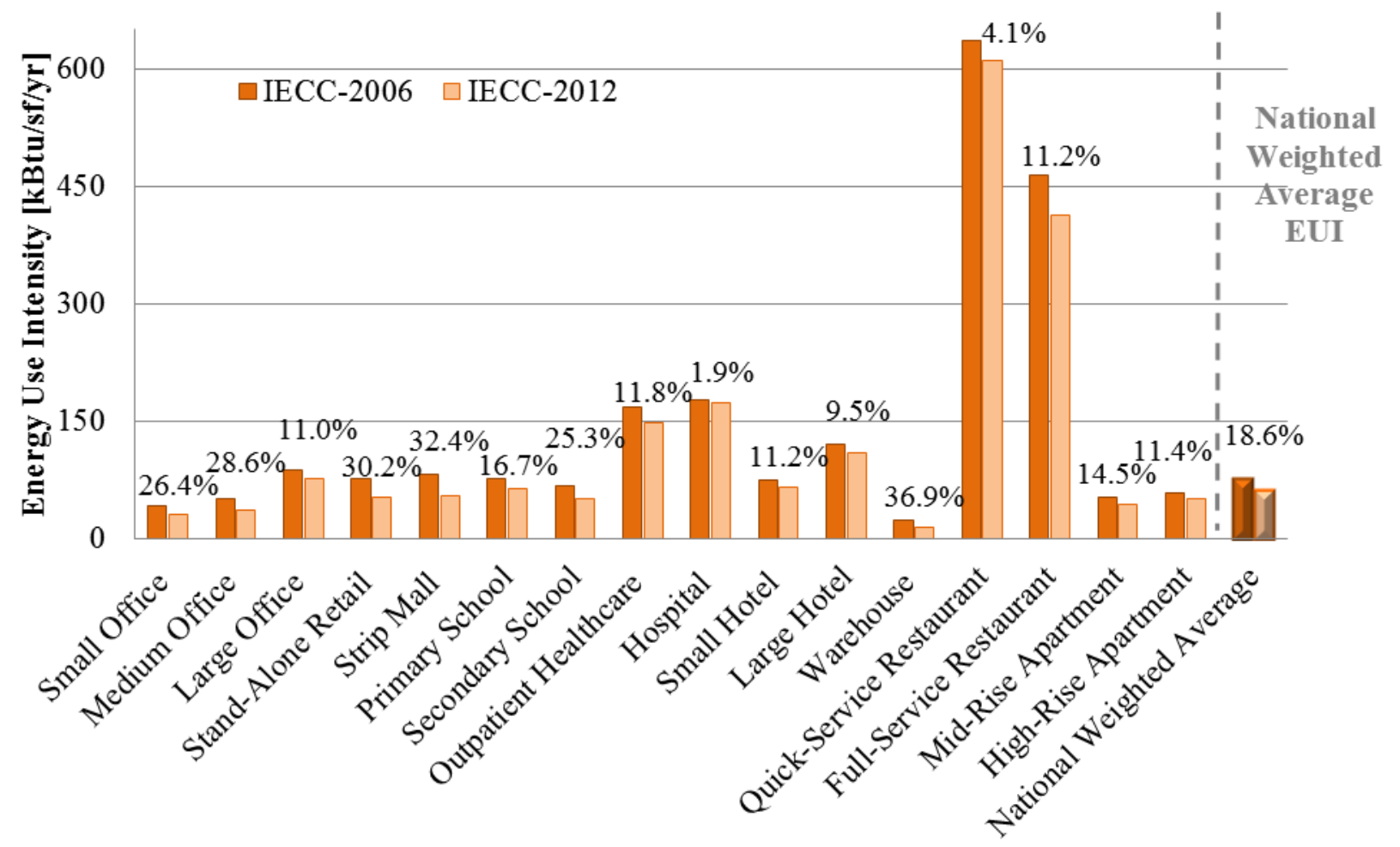

Figure 4.2. 2012 IECC Site Energy Savings Compared to 2006 IECC with Plug-and-Process Loads 
Table 4.2. Site Energy Use Intensity and Savings with Plug-and-Process Loads

\begin{tabular}{lccccc}
\hline \multicolumn{1}{c}{ Prototype Name } & $\begin{array}{c}\text { 2009 IECC } \\
\text { Compared to } \\
\left(\mathrm{kBtu} / \mathrm{ft}^{2} / \mathrm{year}\right)\end{array}$ & $\begin{array}{c}\text { 2009 IECC } \\
\left(\mathrm{kBtu} / \mathrm{ft}^{2} / \mathrm{year}\right)\end{array}$ & $\begin{array}{c}\text { 2006 IECC } \\
(\%)\end{array}$ & $\begin{array}{c}\text { 2012 IECC } \\
\left(\mathrm{kBtu}^{2} \mathrm{ft}^{2} / \mathrm{year}\right)\end{array}$ & $\begin{array}{c}\text { Compared to } \\
\text { 2006 IECC } \\
(\%)\end{array}$ \\
\hline Small Office & 41.5 & 37.8 & 8.9 & 30.5 & 26.4 \\
\hline Medium Office & 50.8 & 45.0 & 11.4 & 36.2 & 28.6 \\
Large Office & 87.4 & 81.9 & 6.2 & 77.7 & 11.0 \\
\hline Stand-Alone Retail & 77.2 & 66.3 & 14.1 & 53.9 & 30.2 \\
\hline Strip Mall & 82.6 & 69.3 & 16.1 & 55.8 & 32.4 \\
\hline Primary School & 76.0 & 70.6 & 7.1 & 63.3 & 16.7 \\
\hline Secondary School & 68.6 & 60.5 & 11.7 & 51.2 & 25.3 \\
\hline Outpatient Healthcare & 167.6 & 152.3 & 9.1 & 147.9 & 11.8 \\
\hline Hospital & 176.8 & 180.8 & -2.2 & 173.4 & 1.9 \\
\hline Small Hotel & 74.6 & 69.1 & 7.3 & 66.2 & 11.2 \\
\hline Large Hotel & 120.7 & 114.3 & 5.3 & 109.3 & 9.5 \\
\hline Warehouse & 24.7 & 21.4 & 13.4 & 15.6 & 36.9 \\
\hline Quick-Service Restaurant & 635.5 & 622.3 & 2.1 & 609.5 & 4.1 \\
\hline Full-Service Restaurant & 464.4 & 430.5 & 7.3 & 412.2 & 11.3 \\
\hline Mid-Rise Apartment & 52.2 & 47.8 & 8.5 & 44.7 & 14.5 \\
\hline High-Rise Apartment & 58.1 & 55.5 & 4.5 & 51.5 & 11.4 \\
\hline National Weighted Average & $\mathbf{7 6 . 3}$ & $\mathbf{6 9 . 7}$ & $\mathbf{8 . 7}$ & $\mathbf{6 2 . 1}$ & $\mathbf{1 8 . 6}$ \\
\hline
\end{tabular}

Table 4.3. Site Energy Cost Index and Energy Cost Savings with Plug-and-Process Loads

\begin{tabular}{|c|c|c|c|c|c|}
\hline Prototype Name & $\begin{array}{l}2006 \text { IECC } \\
\left(\$ / \mathrm{ft}^{2} / \text { year }\right)\end{array}$ & $\begin{array}{l}2009 \text { IECC } \\
\left(\$ / \mathrm{ft}^{2} / \text { year }\right)\end{array}$ & $\begin{array}{c}2009 \text { IECC } \\
\text { Compared to } \\
2006 \text { IECC } \\
(\%)\end{array}$ & $\begin{array}{l}2012 \text { IECC } \\
\left(\$ / \mathrm{ft}^{2} / \text { year }\right)\end{array}$ & $\begin{array}{c}2012 \text { IECC } \\
\text { Compared to } \\
2006 \text { IECC } \\
(\%)\end{array}$ \\
\hline Small Office & 1.23 & 1.13 & 8.7 & 0.91 & 26.1 \\
\hline Medium Office & 1.41 & 1.25 & 11.2 & 1.02 & 27.9 \\
\hline Large Office & 2.43 & 2.34 & 3.6 & 2.24 & 8.0 \\
\hline Stand-Alone Retail & 1.89 & 1.69 & 10.3 & 1.47 & 22.0 \\
\hline Strip Mall & 2.12 & 1.83 & 13.8 & 1.46 & 31.1 \\
\hline Primary School & 1.91 & 1.79 & 6.0 & 1.57 & 17.7 \\
\hline Secondary School & 1.84 & 1.65 & 10.3 & 1.40 & 23.9 \\
\hline Outpatient Healthcare & 4.31 & 3.82 & 11.3 & 3.74 & 13.2 \\
\hline Hospital & 3.99 & 4.09 & -2.5 & 3.92 & 1.9 \\
\hline Small Hotel & 1.74 & 1.62 & 6.7 & 1.54 & 11.8 \\
\hline Large Hotel & 2.68 & 2.57 & 4.4 & 2.46 & 8.3 \\
\hline Warehouse & 0.56 & 0.52 & 8.1 & 0.36 & 35.5 \\
\hline Quick-Service Restaurant & 11.44 & 11.19 & 2.1 & 10.73 & 6.1 \\
\hline Full-Service Restaurant & 9.18 & 8.55 & 6.8 & 7.93 & 13.6 \\
\hline Mid-Rise Apartment & 1.39 & 1.28 & 7.8 & 1.22 & 11.9 \\
\hline High-Rise Apartment & 1.39 & 1.32 & 4.7 & 1.25 & 10.2 \\
\hline National Weighted Average & 1.87 & 1.72 & 7.7 & 1.54 & 17.4 \\
\hline
\end{tabular}


The 2012 IECC results in the highest energy savings for the Warehouse prototype, primarily due to the large increase in envelope insulation requirements. Negative energy savings were observed for the Hospital prototype, due to higher outside air ventilation rates in the 2009 and 2012 IECC models than in the 2006 IECC models. As discussed in Section 3.2.5 of this report, zone ventilation rates in some healthcare spaces in the Outpatient Healthcare and Hospital prototypes were based on outside air requirements in the 2001 edition of Guidelines for Design and Construction of Hospitals and Health Care Facilities (AIA 2001) for the 2006 IECC models. Those for the 2009 and 2012 IECC models were based on the 2006 edition of the Guideline (AIA 2006). For many space types, the 2006 edition has higher zone ventilation requirements than the 2001 edition.

To eliminate the impact of plug-and-process loads end use on the energy savings analysis, Table 4.4 lists the site EUI and energy savings, without plug-and-process loads, for the 2009 IECC and the 2012 IECC as compared to the 2006 IECC. Table 4.5 lists the site energy cost and energy cost savings, without plug-and-process loads, for the 2009 IECC and the 2012 IECC as compared to the 2006 IECC. The 2009 IECC results in $11.2 \%$ energy savings over the 2006 IECC and the 2012 IECC results in $24.3 \%$ energy savings over the 2006 IECC.

Table 4.4. Site Energy Use Intensity and Savings without Plug-and-Process Loads

\begin{tabular}{|c|c|c|c|c|c|}
\hline Prototype Name & $\begin{array}{c}2006 \text { IECC } \\
\left(\mathrm{kBtu} / \mathrm{ft}^{2} / \mathrm{year}\right)\end{array}$ & $\begin{array}{c}2009 \text { IECC } \\
\left(\mathrm{kBtu} / \mathrm{ft}^{2} / \mathrm{year}\right)\end{array}$ & $\begin{array}{c}2009 \text { IECC } \\
\text { Compared to } \\
2006 \text { IECC } \\
(\%) \\
\end{array}$ & $\begin{array}{c}2012 \text { IECC } \\
\left(\mathrm{kBtu} / \mathrm{ft}^{2} / \mathrm{year}\right)\end{array}$ & $\begin{array}{c}2012 \text { IECC } \\
\text { Compared to } \\
2006 \text { IECC } \\
(\%) \\
\end{array}$ \\
\hline Small Office & 32.4 & 28.7 & 11.4 & 21.4 & 33.8 \\
\hline Medium Office & 35.8 & 30.0 & 16.2 & 21.5 & 39.9 \\
\hline Large Office & 43.9 & 38.4 & 12.4 & 34.3 & 21.7 \\
\hline Stand-Alone Retail & 69.7 & 58.8 & 15.6 & 46.4 & 33.5 \\
\hline Strip Mall & 77.2 & 63.9 & 17.3 & 50.4 & 34.7 \\
\hline Primary School & 53.8 & 48.4 & 10.1 & 41.4 & 23.1 \\
\hline Secondary School & 53.9 & 45.9 & 14.9 & 36.7 & 31.9 \\
\hline Outpatient Healthcare & 120.4 & 105.1 & 12.7 & 100.6 & 16.4 \\
\hline Hospital & 127.0 & 131.0 & -3.1 & 123.9 & 2.5 \\
\hline Small Hotel & 52.1 & 46.6 & 10.5 & 43.7 & 16.0 \\
\hline Large Hotel & 84.9 & 78.6 & 7.5 & 73.7 & 13.2 \\
\hline Warehouse & 22.2 & 18.9 & 14.9 & 13.1 & 41.1 \\
\hline Quick-Service Restaurant & 344.0 & 330.8 & 3.8 & 318.0 & 7.6 \\
\hline Full-Service Restaurant & 298.4 & 264.5 & 11.4 & 246.1 & 17.5 \\
\hline Mid-Rise Apartment & 37.7 & 33.2 & 11.8 & 30.1 & 20.1 \\
\hline High-Rise Apartment & 44.9 & 42.3 & 5.9 & 38.4 & 14.4 \\
\hline National Weighted Average & 57.9 & 51.3 & 11.4 & 43.8 & 24.3 \\
\hline
\end{tabular}


Table 4.5. Site Energy Cost Index and Energy Cost Savings without Plug-and-Process Loads

\begin{tabular}{|c|c|c|c|c|c|}
\hline Prototype Name & $\begin{array}{l}2006 \text { IECC } \\
\left(\$ / \mathrm{ft}^{2} / \text { year }\right)\end{array}$ & $\begin{array}{l}2009 \text { IECC } \\
\left(\$ / \mathrm{ft}^{2} / \text { year }\right) \\
\end{array}$ & $\begin{array}{c}2009 \text { IECC } \\
\text { Compared to } \\
2006 \text { IECC } \\
(\%)\end{array}$ & $\begin{array}{l}2012 \text { IECC } \\
\left(\$ / \mathrm{ft}^{2} / \text { year }\right) \\
\end{array}$ & $\begin{array}{c}2012 \text { IECC } \\
\text { Compared to } \\
2006 \text { IECC } \\
(\%) \\
\end{array}$ \\
\hline Small Office & 0.96 & 0.85 & 11.2 & 0.66 & 31.5 \\
\hline Medium Office & 0.98 & 0.82 & 16.3 & 0.62 & 36.5 \\
\hline Large Office & 1.23 & 1.15 & 7.1 & 1.08 & 12.7 \\
\hline Stand-Alone Retail & 1.66 & 1.47 & 11.7 & 1.25 & 25.0 \\
\hline Strip Mall & 1.96 & 1.66 & 15.0 & 1.30 & 33.7 \\
\hline Primary School & 1.39 & 1.28 & 8.2 & 1.06 & 23.9 \\
\hline Secondary School & 1.48 & 1.29 & 12.8 & 1.05 & 29.3 \\
\hline Outpatient Healthcare & 3.01 & 2.52 & 16.2 & 2.46 & 18.1 \\
\hline Hospital & 3.14 & 3.24 & -3.2 & 3.07 & 2.3 \\
\hline Small Hotel & 1.34 & 1.22 & 8.8 & 1.14 & 14.7 \\
\hline Large Hotel & 2.27 & 2.15 & 5.2 & 2.04 & 9.8 \\
\hline Warehouse & 0.48 & 0.44 & 9.4 & 0.29 & 40.5 \\
\hline Quick-Service Restaurant & 8.09 & 7.85 & 3.0 & 7.39 & 8.6 \\
\hline Full-Service Restaurant & 6.61 & 5.98 & 9.5 & 5.39 & 18.4 \\
\hline Mid-Rise Apartment & 0.95 & 0.84 & 11.5 & 0.79 & 16.8 \\
\hline High-Rise Apartment & 1.00 & 0.94 & 6.4 & 0.86 & 13.9 \\
\hline National Weighted Average & 1.45 & 1.30 & 9.9 & 1.13 & 21.8 \\
\hline
\end{tabular}




\subsection{References}

AIA. 2001. AIA Guidelines for Design and Construction of Hospital and Health Care Facilities: 2001 Edition. American Institute of Architects. Washington, D.C.

AIA. 2006. AIA Guidelines for Design and Construction of Hospital and Health Care Facilities: 2006 Edition. American Institute of Architects. Washington, D.C.

ASHRAE. 1999. ANSI/ASHRAE Standard 62-1999. Ventilation for Acceptable Indoor Air Quality. American Society of Heating, Refrigerating and Air-Conditioning Engineers, Atlanta, Georgia.

ANSI/ASHRAE. 2004. ANSI/ASHRAE Standard 62.1-2004, Ventilation for Acceptable Indoor Air Quality. American Society of Heating, Refrigerating and Air-Conditioning Engineers, Atlanta, Georgia.

ANSI/ASHRAE. 2007. ANSI/ASHRAE Standard 62.1-2007, Ventilation for Acceptable Indoor Air Quality. American Society of Heating, Refrigerating and Air-Conditioning Engineers, Atlanta, Georgia.

ANSI/ASHRAE/IESNA. 2004. ANSI/ASHRAE/IESNA 90.1-2004, Energy Standard for Buildings Except Low-Rise Residential Buildings. American Society of Heating, Refrigerating and Air-Conditioning Engineers, Atlanta, Georgia.

ANSI/ASHRAE/IESNA. 2007. ANSI/ASHRAE/IESNA 90.1-2007, Energy Standard for Buildings Except Low-Rise Residential Buildings. American Society of Heating, Refrigerating and Air-Conditioning Engineers, Atlanta, Georgia.

ANSI/ASHRAE/IES. 2010. ANSI/ASHRAE/IES 90.1-2010, Energy Standard for Buildings Except LowRise Residential Buildings. American Society of Heating, Refrigerating and Air-Conditioning Engineers, Atlanta, Georgia.

BECP - U.S. Department of Energy, Building Energy Codes Program. 2012a. Status of State Energy Code Adoption. Accessed October 29, 2012 at http://www.energycodes.gov/adoption/states (last updated October, 2012).

BECP - U.S. Department of Energy, Building Energy Codes Program. 2012b. Commercial Building Prototype Models. Accessed October 23, 2012 at http://www.energycodes.gov/development/commercial/90.1_models (last updated August 24, 2012).

Briggs, RS, RG Lucas, and T Taylor. 2003. "Climate Classification for Building Energy Codes and Standards: Part 2 - Zone Definitions, Maps and Comparisons”, ASHRAE Transactions 109 Part 1: 122-130.

Cho, H, B Liu, and K Gowri. 2010. Energy Saving Impact of ASHRAE 90.1 Vestibule Requirements: Modeling of Air Infiltration through Door Openings. PNNL-20026. Pacific Northwest National Laboratory, Richland, Washington. 
Conover, DR, R Bartlett, and MA Halverson. 2009. Comparison of Standard 90.1-2007 and the 2009 IECC with Respect to Commercial Buildings. PNNL-19054. Pacific Northwest National Laboratory, Richland, Washington.

EIA - U.S. Department of Energy, Energy Information Administration. 2003. Commercial Buildings Energy Consumption Survey 2003. 74 FR 12058, 12071-12073. Accessed October 23, 2012 at 058, 12071-12073. Accessed October 23, 2012 at www.eia.doe.gov/emeu/cbecs/contents.html (last updated October 1, 2012).

EISA - Energy Independence and Security Act. 2007. Energy Conservation Standards for Certain Consumer Products and Commercial and Industrial Equipment. Accessed Oct 31, 2012 at http://www1.eere.energy.gov/buildings/appliance_standards/pdfs/74fr12058.pdf.

Emmerich, S.J., T. McDowell, and W. Anis. 2005. Investigation of the Impact of Commercial Building Envelope Airtightness on HVAC Energy Use. June, 2005. Report No. NISTIR 7238, National Institute of Standards and Technology, Gaithersburg, Maryland.

ECPA - Energy Conservation and Production Act (ECPA) (Pub. L. No. 94-385), as amended by the Energy Policy Act of 1992 (EPACT 1992) (Pub. L. No. 102-486), the Energy Policy Act of 2005 (EPACT 2005) (Pub. L. No. 109-58) and the Energy Independence and Security Act of 2007 (EISA 2007) (Pub. L. No. 110-140).

EPAct - Energy Policy Act. 1992. Energy Policy Act of 1992. Assessed Oct 31, 2012 at http://uscode.house.gov/download/pls/42C81.txt.

Hendron R. 2008. Building America Research Benchmark Definition. NREL/TP-550-44816, National Renewable Energy Laboratory, Golden, Colorado.

ICC 2006a - International Code Council. 2006. 2006 International Energy Conservation Code ${ }^{\circledR}$ Washington D.C.

ICC 2009a- International Code Council. 2009. 2009 International Energy Conservation Code ${ }^{\circledR}$. Washington D.C.

ICC 2012a - International Code Council. 2012. 2012 International Energy Conservation Code ${ }^{\circledR}$ Washington D.C.

ICC 2006b - International Code Council. 2006. 2006 International Mechanical Code®. Washington D.C.

ICC 2009b - International Code Council. 2009. 2009 International Mechanical Code®. Washington D.C.

ICC 2012b - International Code Council. 2012. 2012 International Mechanical Code®. Washington D.C.

ICC 2009c - International Code Council. 2010. 2009 International Energy Conservation Code ${ } — C o d e$ and Commentary. Washington D.C. 
Jarnagin, R.E., and G.K. Bandyopadhyay. 2010. Weighting Factors for the Commercial Building Prototypes Used in the Development of ANSI/ASHRAE/IESNA 90.1-2010. PNNL-19116, Pacific Northwest National Laboratory, Richland, Washington.

Makela, EJ, JL Williamson, and EKB Makela. 2011. Comparison of Standard 90.1-2010 and the 2012 IECC with Respect to Commercial Buildings. PNNL-20770, Pacific Northwest National Laboratory, Richland, Washington.

Richman, EE, E Rauch, J Knappek, J Phillips, K Petty, and P Lopez-Rangel. 2008. "National Commercial Construction Characteristics and Compliance with Building Energy Codes: 1999-2007.” In Scaling Up: Building Tomorrow's Solutions: Proceedings from the 14th ACEEE Summer Study on Energy Efficiency in Buildings, August 17-22, Pacific Grove, California, vol. 3, pp. 3-291 to 3-306. American Council for an Energy-Efficient Economy, Washington, DC.

Thornton, BA, MI Rosenberg, EE Richman, W Wang, Y Xie, J Zhang, H Cho, VV Mendon, RA Athalye, and B Liu. 2011. Achieving the 30\% Goal: Energy and Cost Savings Analysis of ASHRAE Standard 90.1-2010. PNNL-20405, Pacific Northwest National Laboratory, Richland, Washington. 
Appendix A

IECC and Referenced Standard 90.1 


\section{Appendix A}

\section{IECC and Referenced Standard 90.1}

\section{A.1 Energy and Energy Cost Savings for the IECC and Corresponding Standard 90.1}

Section 304(b) of the Energy Conservation and Production Act (ECPA), as amended, requires the Secretary of Energy to make a determination each time a revised version of ASHRAE Standard 90.1 is published with respect to whether the revised standard would improve energy efficiency in commercial buildings. When the U.S. Department of Energy (DOE) issues an affirmative determination on Standard 90.1, states are statutorily required to certify within two years that they have reviewed and updated the commercial provisions of their building energy code, with respect to energy efficiency, to meet or exceed the revised standard. (EPAct 1992 Section 42 USC 6833)

As many states have historically adopted the IECC for both residential and commercial buildings, PNNL has also compared energy performance of ANSI/ASHRAE/IES Standard 90.1 with corresponding editions of the IECC to help states and local jurisdictions make informed decisions regarding model code adoption. Of the 41 States with commercial building energy codes currently, 29 use a version of the IECC (BECP 2012a).

On a national average basis, the 2006 and 2009 IECC are generally equivalent to a corresponding model energy standard (i.e., Standard 90.1-2004 and -2007, respectively); the national weighted site energy and energy cost differences are within plus or minus 1.5\%. For the 2012 IECC, the current analysis results in a 7.4\% increase in national weighted average site energy use and energy cost when compared to Standard 90.1-2010. The national weighted results are summarized in Table A.1 and Figure A.1. When specific building types and climate zones are examined individually, the results vary greatly. For example, the 2010 IECC uses 21\% less energy for a warehouse located in climate zone 5A (likely due to decreased insulation requirements for semi-conditioned spaces in Standard 90.1-2007) to as much as $38 \%$ more energy for a hospital located in climate zone 8. See Appendix D for energy and energy cost comparisons of Standard 90.1-2010 and the 2012 IECC broken down by building type and climate location.

Figure A.2 and Figure A.3 plot the site EUI by prototype for the three IECC editions and three Standard 90.1 editions with and without plug-and-process loads, respectively. Table A.2 and Table A.3 show the site energy savings and energy cost savings, with plug-and-process loads, for the 2006 IECC compared to the Standard 90.1-2004 by prototype and climate zone. Table A.4 and Table A.5 show the site energy savings and energy cost savings, with plug-and-process loads, for the 2009 IECC compared to Standard 90.1-2007 by prototype and climate zone. Table A.6 and Table A.7 show the site energy savings and energy cost savings, with plug-and-process loads, for the 2012 IECC compared to Standard 90.1-2010 by prototype and climate zone. Comparisons between IECC editions and the corresponding Standard 90.1 in energy end-use category level for each prototype are summarized in Appendix C of this report. Energy and energy cost comparisons between Standard 90.1-2010 and the 2012 IECC by climate location and building type are located in Appendix D. 
Table A.1. Site Energy Savings and Site Energy Cost Savings for the IECC and corresponding Standard 90.1 (with Plug-and-Process Loads)

\begin{tabular}{|c|c|c|c|}
\hline & $90.1-2004$ & 2006 IECC & IECC compared to 90.1 \\
\hline EUI (kBtu/ft²/year) & 75.3 & 76.3 & $-1.3 \%$ \\
\hline \multirow[t]{2}{*}{ ECI $\left(\$ / \mathrm{ft}^{2} /\right.$ year $)$} & 1.84 & 1.87 & $-1.4 \%$ \\
\hline & $90.1-2007$ & 2009 IECC & IECC compared to 90.1 \\
\hline EUI (kBtu/ft²/year) & 70.5 & 69.7 & $+1.1 \%$ \\
\hline \multirow[t]{2}{*}{ ECI $\left(\$ / \mathrm{ft}^{2} /\right.$ year $)$} & 1.74 & 1.72 & $+1.1 \%$ \\
\hline & $90.1-2010$ & 2012 IECC & IECC compared to 90.1 \\
\hline EUI (kBtu/ft²/year) & 57.9 & 62.1 & $-7.4 \%$ \\
\hline $\mathrm{ECI}\left(\$ / \mathrm{ft}^{2} /\right.$ year $)$ & 1.44 & 1.54 & $-7.4 \%$ \\
\hline $\begin{array}{l}\mathrm{EUI}=\text { Energy use } \\
\mathrm{ECI}=\text { Energy cos } \\
\text { Data in this table are }\end{array}$ & on a nation & d average & \\
\hline
\end{tabular}

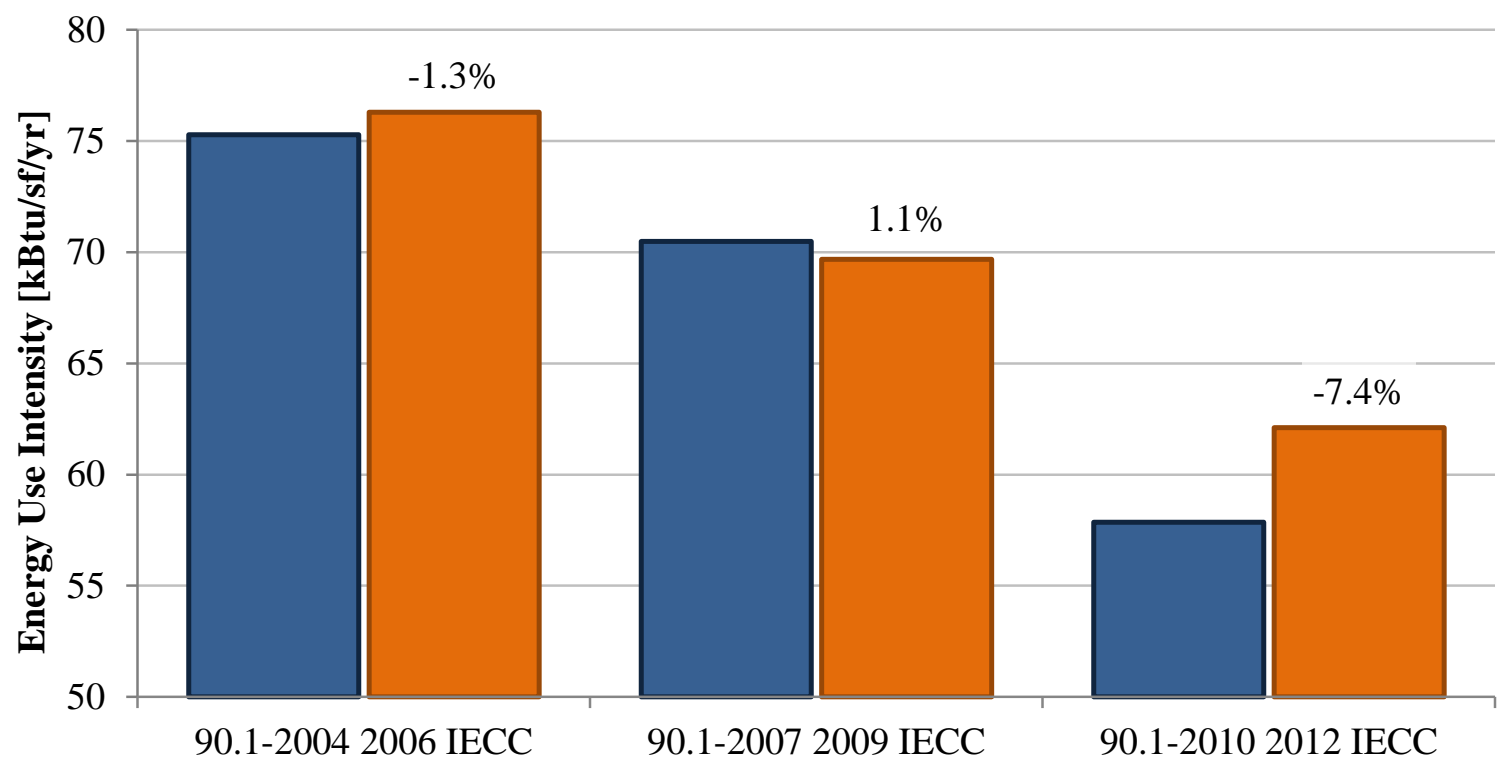

Figure A.1. Site Energy Savings for the IECC and corresponding Standard 90.1 (with Plug-and-Process Loads) 


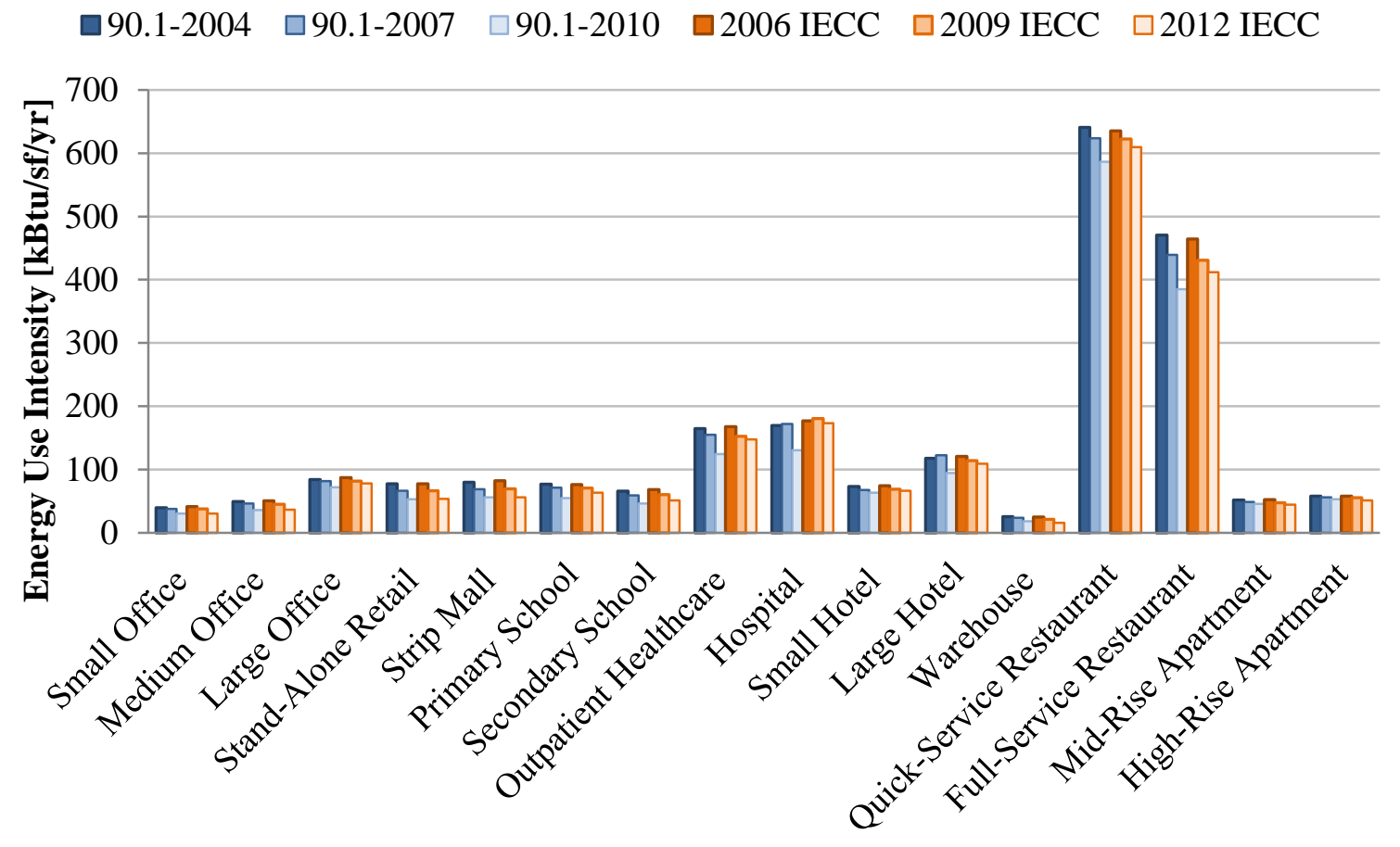

Figure A.2. National Average Energy Use Intensity for all Standard 90.1 and IECC Prototypes with Plug-and-Process Loads

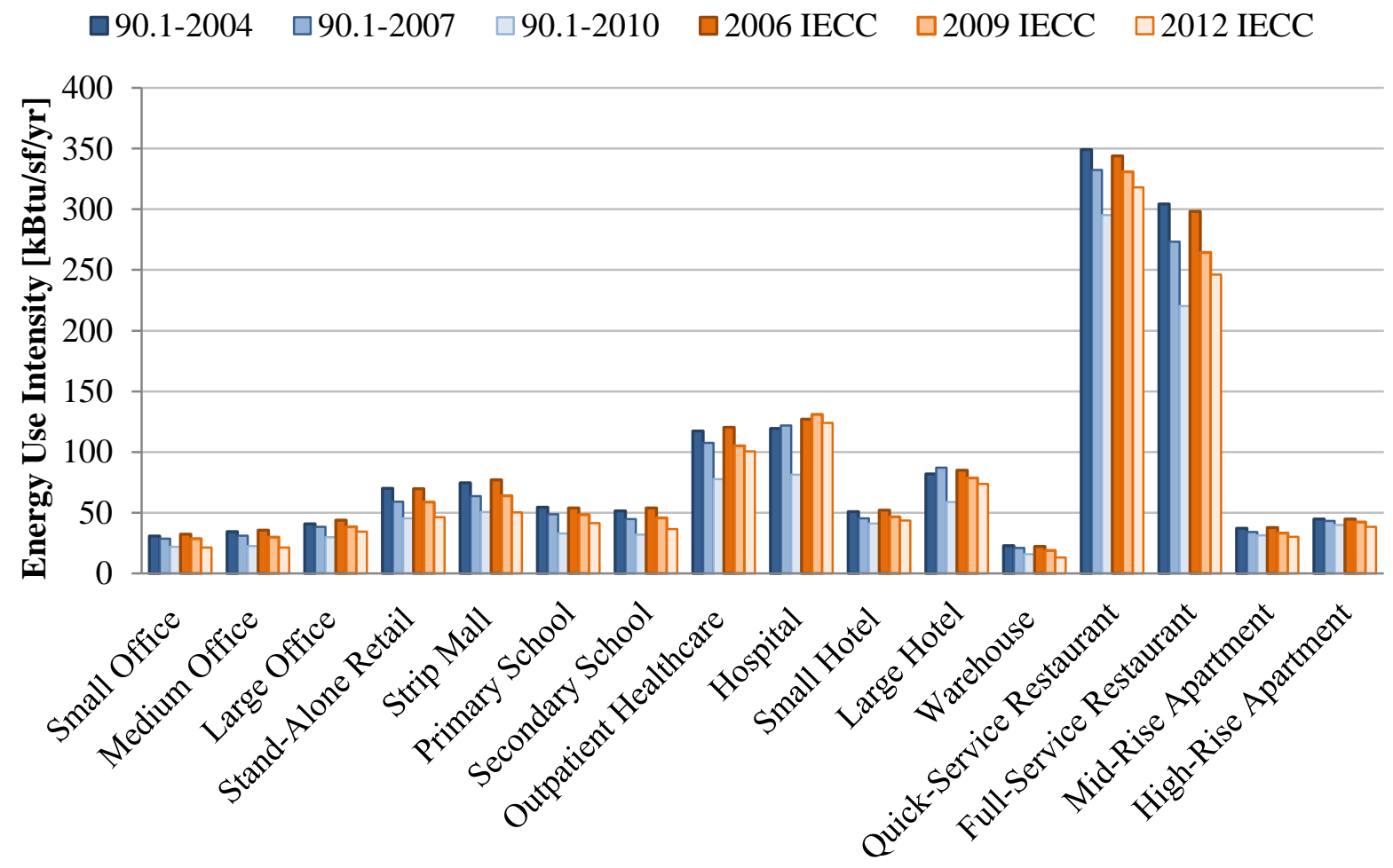

Figure A.3. National Average Energy Use Intensity for all Standard 90.1 and IECC Prototypes without Plug-and-Process Loads 
Table A.2. Site Energy Savings and Energy Cost Savings for the 2006 IECC and Standard 90.1-2004 by Prototype (with Plug-and-Process Loads)

\begin{tabular}{|c|c|c|c|c|c|c|}
\hline \multirow[b]{2}{*}{ Building Prototype } & \multicolumn{3}{|c|}{ Site Energy Use } & \multicolumn{3}{|c|}{ Site Energy Cost } \\
\hline & $\begin{array}{c}\text { Standard } \\
90.1-2004 \\
\left(\mathrm{kBtu} / \mathrm{ft}^{2} / \mathrm{yr}\right)\end{array}$ & $\begin{array}{c}2006 \text { IECC } \\
\left(\mathrm{kBtu} / \mathrm{ft}^{2} / \mathrm{yr}\right)\end{array}$ & $\begin{array}{c}2006 \text { IECC } \\
\text { compared to } \\
90.1-2004(\%)\end{array}$ & $\begin{array}{c}\text { Standard } \\
90.1-2004 \\
\left(\$ / \mathrm{ft}^{2} / \mathrm{yr}\right)\end{array}$ & $\begin{array}{c}2006 \text { IECC } \\
\left(\$ / \mathrm{ft}^{2} / \mathrm{yr}\right)\end{array}$ & $\begin{array}{c}2006 \text { IECC } \\
\text { compared to } \\
90.1-2004(\%)\end{array}$ \\
\hline Small Office & 39.8 & 41.5 & -4.3 & 1.18 & 1.23 & -4.5 \\
\hline Medium Office & 49.4 & 50.8 & -2.8 & 1.40 & 1.41 & -0.7 \\
\hline Large Office & 84.4 & 87.4 & -3.6 & 2.39 & 2.43 & -1.5 \\
\hline Stand-Alone Retail & 77.5 & 77.2 & 0.4 & 1.92 & 1.89 & 1.5 \\
\hline Strip Mall & 80.1 & 82.6 & -3.2 & 2.02 & 2.12 & -5.2 \\
\hline Primary School & 76.7 & 76.0 & 0.9 & 1.90 & 1.91 & -0.2 \\
\hline Secondary School & 66.1 & 68.6 & -3.7 & 1.75 & 1.84 & -5.4 \\
\hline Outpatient Healthcare & 164.6 & 167.6 & -1.8 & 4.24 & 4.31 & -1.5 \\
\hline Hospital & 169.4 & 176.8 & -4.4 & 3.90 & 3.99 & -2.4 \\
\hline Small Hotel & 73.4 & 74.6 & -1.6 & 1.70 & 1.74 & -2.3 \\
\hline Large Hotel & 117.7 & 120.7 & -2.5 & 2.58 & 2.68 & -3.9 \\
\hline Warehouse & 25.5 & 24.7 & 3.2 & 0.56 & 0.56 & 0.4 \\
\hline Quick-Service Restaurant & 640.6 & 635.5 & 0.8 & 11.60 & 11.44 & 1.4 \\
\hline Full-Service Restaurant & 470.3 & 464.4 & 1.2 & 9.37 & 9.18 & 2.0 \\
\hline Mid-Rise Apartment & 51.7 & 52.2 & -1.0 & 1.38 & 1.39 & -0.5 \\
\hline High-Rise Apartment & 57.9 & 58.1 & -0.3 & 1.39 & 1.39 & -0.1 \\
\hline National Weighted Average & 75.3 & 76.3 & -1.3 & 1.84 & 1.87 & -1.4 \\
\hline
\end{tabular}

Table A.3. Site Energy Savings and Energy Cost Savings for the 2006 IECC and Standard 90.1-2004 by Climate Zone (with Plug-and-Process Loads)

\begin{tabular}{|c|c|c|c|c|c|c|c|}
\hline \multirow[b]{2}{*}{ Climate Zone } & \multirow[b]{2}{*}{$\begin{array}{c}\text { Representative } \\
\text { City }\end{array}$} & \multicolumn{3}{|c|}{ Site Energy Use } & \multicolumn{3}{|c|}{ Site Energy Cost } \\
\hline & & $\begin{array}{c}\text { Standard } \\
90.1-2004 \\
\left(\mathrm{kBtu} / \mathrm{ft}^{2} / \mathrm{yr}\right)\end{array}$ & $\begin{array}{c}2006 \text { IECC } \\
\left(\mathrm{kBtu} / \mathrm{ft}^{2} / \mathrm{yr}\right)\end{array}$ & $\begin{array}{c}2006 \text { IECC } \\
\text { compared to } \\
90.12004(\%)\end{array}$ & $\begin{array}{c}\text { Standard } \\
90.1-2004 \\
\text { Cost }\left(\$ / \mathrm{ft}^{2} / \mathrm{yr}\right)\end{array}$ & $\begin{array}{c}2006 \text { IECC } \\
\text { Cost } \\
\left(\$ / \mathrm{ft}^{2} / \mathrm{yr}\right)\end{array}$ & $\begin{array}{c}2006 \text { IECC } \\
\text { compared to } \\
90.12004(\%)\end{array}$ \\
\hline $1 \mathrm{~A}$ & Miami & 62.0 & 63.2 & -1.9 & 1.71 & 1.75 & -2.1 \\
\hline $2 \mathrm{~A}$ & Houston & 71.5 & 72.4 & -1.2 & 1.88 & 1.91 & -1.6 \\
\hline $2 \mathrm{~B}$ & Phoenix & 72.7 & 73.8 & -1.5 & 1.97 & 2.01 & -1.8 \\
\hline $3 \mathrm{~A}$ & Memphis & 71.7 & 72.9 & -1.6 & 1.82 & 1.85 & -1.7 \\
\hline 3B & El Paso & 62.6 & 65.2 & -4.2 & 1.64 & 1.71 & -3.8 \\
\hline $3 \mathrm{C}$ & San Francisco & 60.4 & 59.4 & 1.7 & 1.54 & 1.50 & 2.3 \\
\hline $4 \mathrm{~A}$ & Baltimore & 76.7 & 77.9 & -1.5 & 1.84 & 1.86 & -1.5 \\
\hline $4 \mathrm{~B}$ & Albuquerque & 76.2 & 78.2 & -2.7 & 1.89 & 1.94 & -2.8 \\
\hline $4 \mathrm{C}$ & Salem & 68.2 & 68.4 & -0.4 & 1.65 & 1.66 & -0.7 \\
\hline $5 \mathrm{~A}$ & Chicago & 84.8 & 85.1 & -0.3 & 1.91 & 1.92 & -0.4 \\
\hline $5 B$ & Boise & 76.4 & 77.1 & -1.0 & 1.83 & 1.84 & -0.8 \\
\hline $6 \mathrm{~A}$ & Burlington & 96.7 & 97.7 & -1.0 & 2.12 & 2.13 & -0.7 \\
\hline $6 B$ & Helena & 87.8 & 89.7 & -2.2 & 1.98 & 2.02 & -2.1 \\
\hline 7 & Duluth & 109.4 & 108.7 & 0.7 & 2.27 & 2.26 & 0.6 \\
\hline 8 & Fairbanks & 124.2 & 128.5 & -3.5 & 2.33 & 2.39 & -2.3 \\
\hline \multicolumn{2}{|c|}{ National Weighted Average } & 75.3 & 76.3 & -1.3 & 1.84 & 1.87 & -1.4 \\
\hline
\end{tabular}


Table A.4. Site Energy Savings and Energy Cost Savings for the 2009 IECC and Standard 90.1-2007 by Prototype (with Plug-and-Process Loads)

\begin{tabular}{|c|c|c|c|c|c|c|}
\hline \multirow[b]{2}{*}{ Building Prototype } & \multicolumn{3}{|c|}{ Site Energy Use } & \multicolumn{3}{|c|}{ Site Energy Cost } \\
\hline & $\begin{array}{c}\text { Standard 90.1- } \\
2007 \\
\left(\mathrm{kBtu} / \mathrm{ft}^{2} / \mathrm{yr}\right)\end{array}$ & $\begin{array}{c}2009 \text { IECC } \\
\left(\mathrm{kBtu} / \mathrm{ft}^{2} / \mathrm{yr}\right)\end{array}$ & $\begin{array}{c}2009 \text { IECC } \\
\text { Compared to } \\
90.1-2007(\%)\end{array}$ & $\begin{array}{c}\text { Standard 90.1- } \\
2007 \\
\left(\$ / \mathrm{ft}^{2} / \mathrm{yr}\right)\end{array}$ & $\begin{array}{c}2009 \text { IECC } \\
\left(\$ / \mathrm{ft}^{2} / \mathrm{yr}\right)\end{array}$ & $\begin{array}{c}2009 \text { IECC } \\
\text { Compared to } \\
90.1-2007(\%)\end{array}$ \\
\hline Small Office & 37.7 & 37.8 & -0.1 & 1.13 & 1.13 & 0.0 \\
\hline Medium Office & 46.1 & 45.0 & 2.4 & 1.32 & 1.25 & 5.4 \\
\hline Large Office & 81.9 & 81.9 & -0.1 & 2.36 & 2.34 & 0.7 \\
\hline Stand-Alone Retail & 66.6 & 66.3 & 0.5 & 1.72 & 1.69 & 1.5 \\
\hline Strip Mall & 69.0 & 69.3 & -0.4 & 1.83 & 1.83 & 0.0 \\
\hline Primary School & 71.2 & 70.6 & 0.8 & 1.79 & 1.79 & -0.1 \\
\hline Secondary School & 59.4 & 60.5 & -1.9 & 1.60 & 1.65 & -3.0 \\
\hline Outpatient Healthcare & 154.9 & 152.3 & 1.7 & 4.01 & 3.82 & 4.7 \\
\hline Hospital & 171.7 & 180.8 & -5.3 & 3.91 & 4.09 & -4.7 \\
\hline Small Hotel & 67.8 & 69.1 & -1.9 & 1.58 & 1.62 & -2.6 \\
\hline Large Hotel & 122.8 & 114.3 & 6.9 & 2.54 & 2.57 & -0.8 \\
\hline Warehouse & 23.6 & 21.4 & 9.3 & 0.56 & 0.52 & 7.1 \\
\hline Quick-Service Restaurant & 623.7 & 622.3 & 0.2 & 11.38 & 11.19 & 1.6 \\
\hline Full-Service Restaurant & 439.4 & 430.5 & 2.0 & 8.86 & 8.55 & 3.5 \\
\hline Mid-Rise Apartment & 48.8 & 47.8 & 2.1 & 1.31 & 1.28 & 2.8 \\
\hline High-Rise Apartment & 56.3 & 55.5 & 1.5 & 1.35 & 1.32 & 2.1 \\
\hline National Weighted Average & 70.5 & 69.7 & 1.1 & 1.74 & 1.72 & 1.1 \\
\hline
\end{tabular}

Table A.5. Site Energy Savings and Energy Cost Savings for the 2009 IECC and Standard 90.1-2007 by Climate Zone (with Plug-and-Process Loads)

\begin{tabular}{|c|c|c|c|c|c|c|c|}
\hline \multirow[b]{2}{*}{$\begin{array}{c}\text { Climate } \\
\text { Zone }\end{array}$} & \multirow[b]{2}{*}{$\begin{array}{l}\text { Representative } \\
\text { City }\end{array}$} & \multicolumn{3}{|c|}{ Site Energy Use } & \multicolumn{3}{|c|}{ Site Energy Cost } \\
\hline & & $\begin{array}{c}\text { Standard 90.1- } \\
2007 \\
\left(\mathrm{kBtu} / \mathrm{ft}^{2} / \mathrm{yr}\right)\end{array}$ & $\begin{array}{c}2009 \text { IECC } \\
\left(\mathrm{kBtu} / \mathrm{ft}^{2} / \mathrm{yr}\right)\end{array}$ & $\begin{array}{c}2009 \text { IECC } \\
\text { compared to } \\
90.12007(\%)\end{array}$ & $\begin{array}{l}\text { Standard 90.1- } \\
2007 \\
\text { Cost }\left(\$ / \mathrm{ft}^{2} / \mathrm{yr}\right)\end{array}$ & $\begin{array}{c}2009 \text { IECC } \\
\text { Cost }\left(\$ / \mathrm{ft}^{2} / \mathrm{yr}\right)\end{array}$ & $\begin{array}{c}2009 \text { IECC } \\
\text { compared to } \\
90.12007(\%)\end{array}$ \\
\hline $1 \mathrm{~A}$ & Miami & 60.9 & 60.5 & 0.6 & 1.68 & 1.67 & 0.7 \\
\hline $2 \mathrm{~A}$ & Houston & 67.2 & 66.6 & 1.0 & 1.78 & 1.76 & 0.9 \\
\hline $2 \mathrm{~B}$ & Phoenix & 68.5 & 67.5 & 1.4 & 1.86 & 1.84 & 1.5 \\
\hline $3 \mathrm{~A}$ & Memphis & 67.5 & 66.3 & 1.7 & 1.73 & 1.70 & 1.8 \\
\hline $3 B$ & El Paso & 59.9 & 59.6 & 0.5 & 1.58 & 1.57 & 0.2 \\
\hline $3 C$ & San Francisco & 56.0 & 55.4 & 1.2 & 1.44 & 1.40 & 2.7 \\
\hline $4 \mathrm{~A}$ & Baltimore & 71.9 & 70.4 & 2.1 & 1.74 & 1.71 & 1.7 \\
\hline $4 \mathrm{~B}$ & Albuquerque & 71.9 & 72.0 & -0.1 & 1.80 & 1.80 & 0.0 \\
\hline $4 \mathrm{C}$ & Salem & 63.9 & 63.4 & 0.9 & 1.57 & 1.55 & 1.1 \\
\hline $5 \mathrm{~A}$ & Chicago & 78.2 & 77.4 & 1.0 & 1.79 & 1.77 & 0.8 \\
\hline $5 B$ & Boise & 71.1 & 71.8 & -0.9 & 1.73 & 1.73 & 0.1 \\
\hline $6 \mathrm{~A}$ & Burlington & 88.7 & 88.3 & 0.4 & 1.97 & 1.97 & 0.3 \\
\hline $6 \mathrm{~B}$ & Helena & 81.9 & 82.7 & -1.0 & 1.86 & 1.88 & -1.2 \\
\hline 7 & Duluth & 100.1 & 98.8 & 1.2 & 2.10 & 2.09 & 0.7 \\
\hline 8 & Fairbanks & 110.6 & 113.5 & -2.7 & 2.12 & 2.17 & -2.1 \\
\hline \multicolumn{2}{|c|}{ National Weighted Average } & 70.5 & 69.7 & 1.1 & 1.74 & 1.72 & 1.1 \\
\hline
\end{tabular}


Table A.6. Site Energy Savings and Energy Cost Savings for the 2012 IECC and Standard 90.1-2010 by Prototype (with Plug-and-Process Loads)

\begin{tabular}{|c|c|c|c|c|c|c|}
\hline \multirow[b]{2}{*}{ Building Prototype } & \multicolumn{3}{|c|}{ Site Energy Use } & \multicolumn{3}{|c|}{ Site Energy Cost } \\
\hline & $\begin{array}{c}\text { Standard 90.1- } \\
2010 \\
\left(\mathrm{kBtu} / \mathrm{ft}^{2} / \mathrm{yr}\right)\end{array}$ & $\begin{array}{c}2012 \text { IECC } \\
\left(\mathrm{kBtu} / \mathrm{ft}^{2} / \mathrm{yr}\right)\end{array}$ & $\begin{array}{c}2012 \text { IECC } \\
\text { Compared to } \\
90.1-2010 \\
(\%) \\
\end{array}$ & $\begin{array}{c}\text { Standard 90.1- } \\
2010 \\
\text { Cost }\left(\$ / \mathrm{ft}^{2} / \mathrm{yr}\right)\end{array}$ & $\begin{array}{c}2012 \text { IECC } \\
\text { Cost }\left(\$ / \mathrm{ft}^{2} / \mathrm{yr}\right)\end{array}$ & $\begin{array}{c}2012 \text { IECC } \\
\text { Compared to } \\
90.1-2010 \\
(\%) \\
\end{array}$ \\
\hline Small Office & 30.5 & 30.5 & 0.0 & $\$ 0.91$ & $\$ 0.91$ & 0.2 \\
\hline Medium Office & 36.0 & 36.2 & -0.7 & $\$ 1.02$ & $\$ 1.02$ & -0.2 \\
\hline Large Office & 72.0 & 77.7 & -7.9 & $\$ 2.09$ & $\$ 2.24$ & -6.7 \\
\hline Stand-Alone Retail & 52.8 & 53.9 & -2.0 & $\$ 1.37$ & $\$ 1.47$ & -7.5 \\
\hline Strip Mall & 56.0 & 55.8 & 0.2 & $\$ 1.44$ & $\$ 1.46$ & -1.5 \\
\hline Primary School & 54.8 & 63.3 & -15.7 & $\$ 1.43$ & $\$ 1.57$ & -10.0 \\
\hline Secondary School & 46.3 & 51.2 & -10.6 & $\$ 1.26$ & $\$ 1.40$ & -11.6 \\
\hline Outpatient Healthcare & 124.2 & 147.9 & -19.1 & $\$ 3.20$ & $\$ 3.74$ & -16.9 \\
\hline Hospital & 130.7 & 173.4 & -32.7 & $\$ 3.13$ & $\$ 3.92$ & -25.4 \\
\hline Small Hotel & 63.3 & 66.2 & -4.6 & $\$ 1.44$ & $\$ 1.54$ & -6.5 \\
\hline Large Hotel & 94.3 & 109.3 & -15.9 & $\$ 2.10$ & $\$ 2.46$ & -17.0 \\
\hline Warehouse & 18.2 & 15.6 & 14.5 & $\$ 0.42$ & $\$ 0.36$ & 13.0 \\
\hline Quick-Service Restaurant & 586.6 & 609.5 & -3.9 & $\$ 10.17$ & $\$ 10.73$ & -5.5 \\
\hline Full-Service Restaurant & 385.2 & 412.2 & -7.0 & $\$ 7.36$ & $\$ 7.93$ & -7.8 \\
\hline Mid-Rise Apartment & 45.7 & 44.7 & 2.3 & $\$ 1.26$ & $\$ 1.22$ & 2.8 \\
\hline High-Rise Apartment & 52.9 & 51.5 & 2.7 & $\$ 1.29$ & $\$ 1.25$ & 3.3 \\
\hline National Weighted Average & 57.9 & 62.1 & -7.4 & $\$ 1.44$ & $\$ 1.54$ & -7.4 \\
\hline
\end{tabular}

Table A.7. Site Energy Savings and Energy Cost Savings for the 2012 IECC and Standard 90.1-2010 by Climate Zone (with Plug-and-Process Loads)

\begin{tabular}{|c|c|c|c|c|c|c|c|}
\hline \multirow[b]{2}{*}{$\begin{array}{c}\text { Climate } \\
\text { Zone }\end{array}$} & \multirow[b]{2}{*}{$\begin{array}{l}\text { Representative } \\
\text { City }\end{array}$} & \multicolumn{3}{|c|}{ Site Energy Use } & \multicolumn{3}{|c|}{ Site Energy Cost } \\
\hline & & $\begin{array}{c}\text { Standard 90.1- } \\
2010 \\
\left(\mathrm{kBtu} / \mathrm{ft}^{2} / \mathrm{yr}\right)\end{array}$ & $\begin{array}{c}2012 \text { IECC } \\
\left(\mathrm{kBtu} / \mathrm{ft}^{2} / \mathrm{yr}\right)\end{array}$ & $\begin{array}{c}2012 \text { IECC } \\
\text { compared to } \\
90.12010 \\
(\%)\end{array}$ & $\begin{array}{c}\text { Standard } \\
90.1-2010 \\
\text { Cost } \\
\left(\$ / \mathrm{ft}^{2} / \mathrm{yr}\right)\end{array}$ & $\begin{array}{c}2012 \text { IECC } \\
\text { Cost } \\
\left(\$ / \mathrm{ft}^{2} / \mathrm{yr}\right)\end{array}$ & $\begin{array}{c}2012 \text { IECC } \\
\text { compared to } \\
90.12010 \\
(\%)\end{array}$ \\
\hline $1 \mathrm{~A}$ & Miami & 53.9 & 53.9 & 0.1 & 1.48 & 1.47 & 0.5 \\
\hline $2 \mathrm{~A}$ & Houston & 55.5 & 58.6 & -5.6 & 1.46 & 1.54 & -5.1 \\
\hline $2 \mathrm{~B}$ & Phoenix & 56.4 & 59.2 & -4.9 & 1.53 & 1.59 & -4.2 \\
\hline $3 \mathrm{~A}$ & Memphis & 54.8 & 59.7 & -9.0 & 1.40 & 1.52 & -8.5 \\
\hline $3 B$ & El Paso & 50.6 & 54.2 & -7.1 & 1.32 & 1.42 & -7.0 \\
\hline $3 \mathrm{C}$ & San Francisco & 47.8 & 51.5 & -7.8 & 1.23 & 1.32 & -7.1 \\
\hline $4 \mathrm{~A}$ & Baltimore & 59.2 & 63.2 & -6.7 & 1.44 & 1.55 & -7.6 \\
\hline $4 \mathrm{~B}$ & Albuquerque & 60.4 & 65.7 & -8.6 & 1.49 & 1.63 & -9.1 \\
\hline $4 \mathrm{C}$ & Salem & 54.0 & 58.3 & -7.8 & 1.32 & 1.43 & -8.1 \\
\hline $5 \mathrm{~A}$ & Chicago & 62.7 & 68.2 & -8.6 & 1.46 & 1.59 & -8.9 \\
\hline $5 B$ & Boise & 59.8 & 65.0 & -8.7 & 1.43 & 1.57 & -9.5 \\
\hline $6 \mathrm{~A}$ & Burlington & 70.0 & 76.6 & -9.4 & 1.60 & 1.75 & -9.1 \\
\hline $6 \mathrm{~B}$ & Helena & 67.0 & 73.5 & -9.7 & 1.54 & 1.69 & -10.3 \\
\hline 7 & Duluth & 77.6 & 85.7 & -10.5 & 1.69 & 1.86 & -10.4 \\
\hline 8 & Fairbanks & 88.4 & 92.3 & -4.5 & 1.73 & 1.83 & -5.9 \\
\hline \multicolumn{2}{|c|}{ National Weighted Average } & 57.9 & 62.1 & -7.4 & 1.44 & 1.54 & -7.4 \\
\hline
\end{tabular}




\section{A.2 Key Differences between Standard 90.1-2010 and the 2012 IECC Prototype Models}

Table A.8 includes descriptions of the key differences between Standard 90.1-2010 and the 2012 IECC. The table is organized by end-use category. For each requirement area where there is a modeled difference between the standard and code, a description of the difference is provided.

Each difference is coded to indicate which standard or code will use more energy, based on a qualitative assessment of the relative provisions within the IECC and Standard 90.1. Where the 2012 IECC is expected to use less energy than Standard 90.1-2010, a less than sign $(<)$ is used. Where the 2012 IECC is expected to use more energy, a "greater than" sign $(>)$ is used. While the individual energy impact for each item was not determined, an estimate is made of the magnitude of difference overall and multiple symbols are used when the magnitude is expected to be greater. For example, the lack of a dynamic ventilation efficiency reset requirement in 2012 IECC is expected to have a large impact on energy use, so a triple symbol is used ( $>>>$ ). PNNL identified a series of amendments to the 2012 IECC that would better align the requirements with Standard 90.1-2010 to create parity on a nationally aggregated basis. Those amendments are located in Appendix B.

Table A.8. Description of the Key Differences between Standard 90.1-2010 and the 2012 IECC

\begin{tabular}{|c|c|c|}
\hline Requirement Area & $\begin{array}{l}2012 \text { IECC } \\
\text { Energy Use } \\
\text { Compared to } \\
90.1-2010\end{array}$ & Key Differences Between Standard 90.1-2010 and 2012 IECC Prototype Models \\
\hline \multicolumn{3}{|l|}{ Building envelope } \\
\hline $\begin{array}{l}\text { Opaque envelope } \\
\text { insulation level }\end{array}$ & $<<$ & $\begin{array}{l}\text { The opaque insulation requirements in the } 2012 \text { IECC are generally more stringent } \\
\text { than Standard 90.1-2010. }\end{array}$ \\
\hline $\begin{array}{l}\text { Semi-heated space } \\
\text { envelope } \\
\text { requirements }\end{array}$ & $<<$ & $\begin{array}{l}\text { The } 2012 \text { IECC envelope requirements do not have a category for semi-heated spaces } \\
\text { and the fully conditioned space insulation level is required in the } 2012 \text { IECC } \\
\text { Warehouse prototype. Standard } 90.1-2010 \text { has lower insulation requirements for the } \\
\text { semi-heated spaces found in the warehouse. }\end{array}$ \\
\hline $\begin{array}{l}\text { Fenestration } \\
\text { requirements }\end{array}$ & $<<$ & $\begin{array}{l}\text { The } 2012 \text { IECC is considerably more stringent than Standard } 90.1-2010 \text { for both } \\
\text { vertical fenestration U-factor and SHGC as well as skylight U-factor and SHGC. }\end{array}$ \\
\hline $\begin{array}{l}\text { Continuous air } \\
\text { barrier }\end{array}$ & $>>$ & $\begin{array}{l}\text { Continuous air barriers are required in Standard } 90.1-2010 \text { as well as the } 2012 \text { IECC, } \\
\text { with the main difference that air barriers are exempted in CZ 1, 2, } 3 \text { in the } 2012 \text { IECC. }\end{array}$ \\
\hline Vestibule & $>>$ & $\begin{array}{l}\text { Standard 90.1-2010 requires vestibules with multiple exceptions by climate zone and } \\
\text { building size. The } 2012 \text { IECC has a different set of exceptions. The } 2012 \text { IECC does } \\
\text { not exempt smaller buildings in climate zone } 3 \text {. However, the } 2012 \text { IECC exempts } \\
\text { building entrance doors that open up to a space less than } 3,000 \text { sf (most prototypes) } \\
\text { while } 90.1 \text { does not. In the mix of buildings modeled in the prototypes, Standard 90.1- } \\
2010 \text { was found to require more vestibules. }\end{array}$ \\
\hline $\begin{array}{l}\text { Cool roof } \\
\text { requirements }\end{array}$ & $<$ & $\begin{array}{l}\text { Cool roof requirements are essentially similar for both the } 2012 \text { IECC and } \\
\text { Standard 90.1-2010. However, the } 2012 \text { IECC does not exempt cool roofs over semi- } \\
\text { heated spaces, so a cool roof is included for the Warehouse prototype in the } 2012 \\
\text { IECC, but not in Standard 90.1-2010. }\end{array}$ \\
\hline $30 \%$ WWR & $<<$ & $\begin{array}{l}\text { The } 2012 \text { IECC requires WWR less than } 30 \% \text { and Standard 90.1-2010 requires WWR } \\
\text { less than } 40 \% \text {. This impact only the Primary School, Secondary School, Medium } \\
\text { Office, and Large Office. }\end{array}$ \\
\hline
\end{tabular}


Table A.8. (continued)

\begin{tabular}{|c|c|c|}
\hline Requirement Area & $\begin{array}{l}2012 \text { IECC } \\
\text { Energy Use } \\
\text { Compared to } \\
90.1-2010\end{array}$ & Key Differences Between Standard 90.1-2010 and 2012 IECC Prototype Models \\
\hline \multicolumn{3}{|c|}{ Building Mechanical Systems } \\
\hline $\begin{array}{l}\text { Shutoff Damper } \\
\text { Controls }\end{array}$ & $>$ & $\begin{array}{l}\text { The } 2012 \text { IECC exempts buildings with less than } 3 \text { stories from the motorized damper } \\
\text { requirement. Standard 90.1-2010 does not have such exception. }\end{array}$ \\
\hline $\begin{array}{l}\text { Optimal start for } \\
\text { small units }\end{array}$ & $<<$ & $\begin{array}{l}\text { Standard 90.1-2010 only requires optimal start for air-handling units with supply fan } \\
\text { size over 10,000 cfm. The } 2012 \text { IECC does not have a threshold; therefore, more } \\
\text { systems in the } 2012 \text { IECC models are required to have optimal start. }\end{array}$ \\
\hline $\begin{array}{l}\text { Economizer } \\
\text { threshold }\end{array}$ & $<$ & $\begin{array}{l}\text { The } 2012 \text { IECC requires economizers for cooling systems with a capacity of 33,000 } \\
\text { Btu/h or larger. The capacity threshold in Standard } 90.1-2010 \text { is } 54,000 \mathrm{Btu} / \mathrm{h} \text {. Thus, } \\
\text { more units are required to have economizers for the IECC. }\end{array}$ \\
\hline $\begin{array}{l}\text { Multiple-zone } \\
\text { system ventilation } \\
\text { optimization }\end{array}$ & $>>>$ & $\begin{array}{l}\text { Standard 90.1-2010 allows VAV zone MDP higher than prescriptive maximums ( } 20 \% \\
\text { or 30\%) if an overall system annual energy usage reduction can be demonstrated. } \\
\text { Optimizing these MDPs resulted in significant outdoor airflow reduction in the } \\
\text { Standard 90.1-2010 models. The } 2012 \text { IECC does not have such a provision, and in } \\
\text { many cases very high outside airflow rates are needed to satisfy the ventilation } \\
\text { requirements of the multi-space ventilation requirements. }\end{array}$ \\
\hline $\begin{array}{l}\text { Dynamic } \\
\text { ventilation reset }\end{array}$ & $>>$ & $\begin{array}{l}\text { Standard 90.1-2010 requires multiple-zone VAV systems with direct digital control of } \\
\text { terminal units to include a means to automatically reduce outdoor air intake flow } \\
\text { below the design rate in response to changes in system ventilation efficiency due to } \\
\text { increases in zone airflow to meet thermal load requirements. This requirement is not } \\
\text { present in the } 2012 \text { IECC. }\end{array}$ \\
\hline $\begin{array}{l}\text { Supply air } \\
\text { temperature reset }\end{array}$ & $<$ & $\begin{array}{l}\text { Standard 90.1-2010 requires supply air temperature (SAT) reset in all seven } \\
\text { prototypes with VAV systems except in climate subzone 1A, 2A, and 3A. The } 2012 \\
\text { IECC requires SAT reset in the same buildings in all climate zones. }\end{array}$ \\
\hline $\begin{array}{l}\text { VAV required in } \\
\text { healthcare } \\
\text { buildings }\end{array}$ & $>>$ & $\begin{array}{l}\text { Standard 90.1-2010 requires VAV turndown for zones with special pressurization } \\
\text { requirements such as laboratories and some areas of hospitals. The } 2012 \text { IECC does } \\
\text { not have a similar requirement; therefore, systems serving those space types apply } \\
\text { constant volume reheat systems. This difference affects Outpatient Healthcare and } \\
\text { Hospital. }\end{array}$ \\
\hline $\begin{array}{l}\text { Kitchen } \\
\text { ventilation }\end{array}$ & $>>$ & $\begin{array}{l}\text { Standard 90.1-2010 requires transfer air from adjacent spaces to be used for kitchen } \\
\text { ventilation before any other makeup air is introduced to the kitchen. In addition, } \\
\text { Standard } 90.1-2010 \text { requires highly efficient hood types if the total kitchen exhaust is } \\
\text { over 5,000 cfm. The } 2012 \text { IECC does not have any similar requirement, so kitchen } \\
\text { makeup and hood airflows are allowed to be higher. }\end{array}$ \\
\hline Single-zone VAV & $>>$ & $\begin{array}{l}\text { Standard 90.1-2010 requires single-zone fans to reduce airflow in certain conditions } \\
\text { for DX cooling units with cooling capacity of 110,000 Btu/h and greater. The } 2012 \\
\text { IECC does not have a similar requirement. }\end{array}$ \\
\hline \multicolumn{3}{|c|}{ Electrical Power and Lighting Systems } \\
\hline Interior LPD & $<<$ & $\begin{array}{l}\text { The high-efficiency lighting option from Section C } 406 \text { of the } 2012 \text { IECC was selected } \\
\text { to develop the } 2012 \text { IECC prototypes. With that option, the } 2012 \text { IECC LPD is } \\
\text { generally lower than the Standard 90.1-2010 requirement. }\end{array}$ \\
\hline Sidelighting & $>$ & $\begin{array}{l}\text { The } 2012 \text { IECC does not require automatic or multilevel controls for spaces with } \\
\text { sidelighting, only manual controls for general lighting separately in sidelit daylight } \\
\text { zones. Standard 90.1-2010 is more stringent than the } 2012 \text { IECC because it requires } \\
\text { automatic multilevel controls for primary sidelit areas. No sidelighting controls are } \\
\text { required for the } 2012 \text { IECC. }\end{array}$ \\
\hline
\end{tabular}


Table A.8. (continued)

\begin{tabular}{|c|c|c|}
\hline Requirement Area & $\begin{array}{l}2012 \text { IECC } \\
\text { Energy Use } \\
\text { Compared to } \\
90.1-2010\end{array}$ & Key Differences Between Standard 90.1-2010 and 2012 IECC Prototype Models \\
\hline $\begin{array}{l}\text { Exterior lighting } \\
\text { control }\end{array}$ & $>>$ & $\begin{array}{l}\text { Standard 90.1-2010 requires exterior lighting to have bi-level control and proximity } \\
\text { sensors for general all-night applications (e.g., parking lots) to reduce lighting when } \\
\text { not needed. It also requires control of facade and landscaping lighting not needed } \\
\text { after midnight. The } 2012 \text { IECC does not require exterior lighting controls beyond } \\
\text { photocells or astronomical time controls. }\end{array}$ \\
\hline $\begin{array}{l}\text { Sleeping unit } \\
\text { (hotel guestroom) } \\
\text { LPD }\end{array}$ & $>>$ & $\begin{array}{l}\text { The } 2012 \text { IECC exempts sleeping units from LPD requirements. Standard 90.1-2010 } \\
\text { does not have such an exemption, and the allowed LPD is assumed to be lower than } \\
\text { the } 2012 \text { IECC. This difference affects the Small and Large Hotels. }\end{array}$ \\
\hline $\begin{array}{l}\text { Dwelling unit } \\
\text { (apartment) LPD }\end{array}$ & $<<$ & $\begin{array}{l}\text { The } 2012 \text { IECC require } 75 \% \text { of all permanently installed luminaires in dwelling units } \\
\text { to be high efficacy. Standard 90.1-2010 exempts dwelling unit from LPD } \\
\text { requirements. This difference affects the Mid-Rise and High-Rise Apartments. }\end{array}$ \\
\hline
\end{tabular}


Table A.9. Characterization of Key Differences between Standard 90.1-2010 and the 2012 IECC

\begin{tabular}{|c|c|c|c|c|c|c|c|c|c|c|c|c|c|c|c|c|c|}
\hline Requirement Area & $\begin{array}{c}2012 \text { IECC } \\
\text { Energy Use } \\
\text { Compared to } \\
\text { Standard } 90.1 \\
-2010 \\
\end{array}$ & 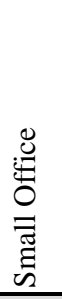 & 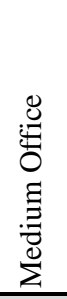 & 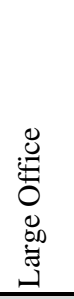 & 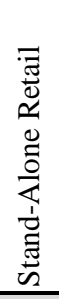 & 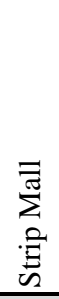 & 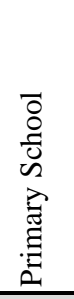 & 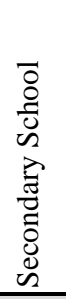 & 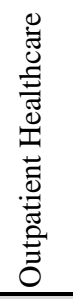 & 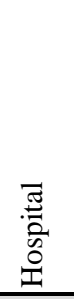 & 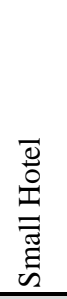 & 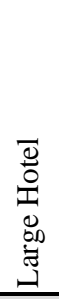 & 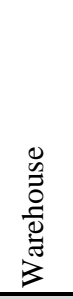 & 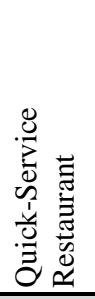 & 苞 & 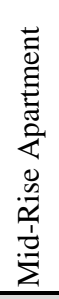 & 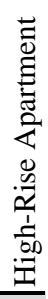 \\
\hline \multicolumn{18}{|c|}{ Building envelope } \\
\hline Opaque envelope insulation level & $<<$ & $\mathrm{X}$ & $\mathrm{X}$ & $\mathrm{X}$ & $\mathrm{X}$ & $\mathrm{X}$ & $\mathrm{X}$ & $\mathrm{X}$ & $\mathrm{X}$ & $\mathrm{X}$ & $\mathrm{X}$ & $\mathrm{X}$ & $\mathrm{X}$ & & & $\mathrm{X}$ & $\mathrm{X}$ \\
\hline Semi-heated space envelope requirements & $<<$ & & & & & & & & & & & & $\mathrm{X}$ & & & & \\
\hline Fenestration requirements & $<<$ & $\mathrm{X}$ & $\mathrm{X}$ & $\mathrm{X}$ & $\mathrm{X}$ & $\mathrm{X}$ & $\mathrm{X}$ & $\mathrm{X}$ & $\mathrm{X}$ & $\mathrm{X}$ & $\mathrm{X}$ & $\mathrm{X}$ & $\mathrm{X}$ & $\mathrm{X}$ & $\mathrm{X}$ & $\mathrm{X}$ & $\mathrm{X}$ \\
\hline Continuous air barrier & $>>$ & $\mathrm{X}$ & $\mathrm{x}$ & $\mathrm{X}$ & $\mathrm{X}$ & $\mathrm{X}$ & $\mathrm{x}$ & $\mathrm{X}$ & $\mathrm{x}$ & $\mathrm{X}$ & $\mathrm{X}$ & $\mathrm{x}$ & $\mathrm{X}$ & $\mathrm{x}$ & $\mathrm{X}$ & $\mathrm{X}$ & $\mathrm{X}$ \\
\hline Vestibule & $>>$ & $\mathrm{X}$ & $\mathrm{X}$ & & & & $\mathrm{X}$ & $\mathrm{X}$ & $\mathrm{X}$ & & $\mathrm{X}$ & & $\mathrm{X}$ & $\mathrm{x}$ & $\mathrm{X}$ & $\mathrm{X}$ & $\mathrm{X}$ \\
\hline Cool roof requirements & $<$ & & & & & & & & & & & & $\mathrm{X}$ & & & & \\
\hline $30 \%$ WWR & $<<$ & & $\mathrm{X}$ & $\mathrm{X}$ & & & $\mathrm{X}$ & $\mathrm{X}$ & & & & & & & & & \\
\hline \multicolumn{18}{|c|}{ Building mechanical systems } \\
\hline Shutoff Damper Controls & $>$ & $\mathrm{x}$ & & & $\mathrm{X}$ & $\mathrm{X}$ & $\mathrm{X}$ & $\mathrm{X}$ & & & & & $\mathrm{X}$ & $\mathrm{x}$ & $\mathrm{X}$ & & \\
\hline Optimal start for small units & $<<$ & $\mathrm{X}$ & & & $\mathrm{X}$ & $\mathrm{X}$ & $\mathrm{X}$ & $\mathrm{X}$ & & & & & $\mathrm{X}$ & $\mathrm{x}$ & $\mathrm{X}$ & $\mathrm{x}$ & $\mathrm{X}$ \\
\hline Economizer threshold & $<$ & & $\mathrm{X}$ & $\mathrm{X}$ & $\mathrm{X}$ & $\mathrm{X}$ & $\mathrm{X}$ & $\mathrm{X}$ & $\mathrm{X}$ & $\mathrm{X}$ & $\mathrm{X}$ & $\mathrm{X}$ & $\mathrm{X}$ & $\mathrm{X}$ & $\mathrm{X}$ & & \\
\hline Multiple-zone system Ventilation optimization & $>>$ & & & $\mathrm{X}$ & & & $\mathrm{X}$ & $\mathrm{X}$ & $\mathrm{X}$ & $\mathrm{X}$ & & $\mathrm{x}$ & & & & & \\
\hline Dynamic ventilation reset & >>> & & & $\mathrm{X}$ & & & $\mathrm{X}$ & $\mathrm{X}$ & $\mathrm{X}$ & $\mathrm{X}$ & & $\mathrm{x}$ & & & & & \\
\hline SAT reset & $<$ & $\mathrm{X}$ & $\mathrm{X}$ & $\mathrm{X}$ & $\mathrm{X}$ & $\mathrm{x}$ & $\mathrm{X}$ & $\mathrm{x}$ & $\mathrm{x}$ & $\mathrm{X}$ & $\mathrm{X}$ & $\mathrm{x}$ & $\mathrm{X}$ & $\mathrm{X}$ & $\mathrm{X}$ & $\mathrm{X}$ & $\mathrm{X}$ \\
\hline VAV required in healthcare buildings & $>>>$ & & & & & & & & $\mathrm{X}$ & $\mathrm{X}$ & & & & & & & \\
\hline Kitchen ventilation & $>>$ & & & & & & $\mathrm{X}$ & $\mathrm{X}$ & & $\mathrm{X}$ & & $\mathrm{X}$ & & $\mathrm{X}$ & $\mathrm{X}$ & & \\
\hline Single-zone VAV & $>>$ & & & & $\mathrm{X}$ & & $\mathrm{X}$ & $\mathrm{X}$ & & & & & & $\mathrm{X}$ & $\mathrm{X}$ & & \\
\hline \multicolumn{18}{|c|}{ Electrical power and lighting systems } \\
\hline Interior LPD & $<<$ & $\mathrm{X}$ & $\mathrm{X}$ & $\mathrm{X}$ & $\mathrm{X}$ & $\mathrm{X}$ & $\mathrm{X}$ & & $\mathrm{X}$ & $\mathrm{X}$ & & & $\mathrm{X}$ & $\mathrm{X}$ & $\mathrm{X}$ & $\mathrm{X}$ & $\mathrm{X}$ \\
\hline Sidelighting & $>$ & & & $\mathrm{X}$ & & & $\mathrm{X}$ & $\mathrm{X}$ & $\mathrm{X}$ & $\mathrm{X}$ & $\mathrm{X}$ & $\mathrm{x}$ & $\mathrm{x}$ & $\mathrm{x}$ & $\mathrm{X}$ & & \\
\hline Exterior lighting control & $>>$ & $\mathrm{X}$ & $\mathrm{x}$ & $\mathrm{X}$ & $\mathrm{x}$ & $\mathrm{X}$ & $\mathrm{X}$ & $\mathrm{X}$ & & & & $\mathrm{x}$ & $\mathrm{X}$ & $\mathrm{x}$ & $\mathrm{X}$ & & \\
\hline Sleeping unit (hotel guestroom) LPD & $>>$ & & & & & & & & & & $\mathrm{X}$ & $\mathrm{x}$ & & & & & \\
\hline Dwelling unit (apartment) LPD & $<<$ & & & & & & & & & & & & & & & $\mathrm{X}$ & $\mathrm{X}$ \\
\hline
\end{tabular}

Table A.6 shows which prototypes in the IECC analysis and the PI analysis are affected by the differences between Standard 90.1-2010 and the 2012 IECC. The table is organized by building system, and an X indicates that for the noted item, a difference between Standard $90.1-2010$ and the 2012 IECC occurs. 
Appendix B

Amendments to the 2012 IECC to Align with Standard 90.1-2010 


\section{Appendix B}

\section{Amendments to the 2012 IECC to Align with Standard 90.1-2010}

\section{B.1 Proposed Amendments to Align the 2012 IECC with Standard 90.1-2010}

PNNL identified a series of amendments to the 2012 IECC that would better align the requirements with Standard 90.1-2010 to create parity on a nationally aggregated basis. States can use these amendments as they engage individual processes to review and update their building codes with respect to energy efficiency. Amendments provided are a resource for each state's consideration as they tailor their state building code to their individual needs. DOE provides the amendments to allow state options and ease the burden of meeting the statutory requirement. A summary of each suggested amendment is provided below along with specific code change language to be applied to the 2012 IECC shown with inserted and deleted text. Tables B1 and B2 show the impact of adding these amendments to the 2012 IECC and the difference with Standard $90.1-2010$ by building type and climate zone, respectively. The tables show that the addition of this package of amendments will result in a national weighted site energy cost for the 2012 IECC of within $0.2 \%$ of Standard $90.1-2010$ and energy use within $0.8 \%$.

\section{B.1.1 Continuous Air Barrier}

\section{Purpose:}

Increase the coverage of the continuous air barrier requirements in the IECC to limit uncontrolled infiltration in climate zones 1 , 2, and 3 resulting in reduced heating and cooling loads.

\section{Specific Amendment to 2012 IECC}

Delete the exception to Section C402.4.1:

C402.4.1 Air barriers. A continuous air barrier shall be provided throughout the building thermal envelope. The air barriers shall be permitted to be located on the inside or outside of the building envelope, located within the assemblies composing the envelope, or any combination thereof. The air barrier shall comply with Sections C402.4.1.1 and C402.4.1.2.

Exception: Air barriers are not required in buildings located in Climate Zones 1, 2 and 3.

\section{B.1.2 Shutoff Damper Controls}

\section{Purpose:}

Increase the circumstances under which positive-closure outside air dampers are required. Energy is saved by reducing infiltration of outside air and exfiltration of conditioned air through outside air openings during unoccupied periods and morning warm-up and cool-down, resulting in reduced heating and cooling. 


\section{Specific Amendment to 2012 IECC:}

Revise Sections C402.4.5 and C403.2.4.4; renumber and revise Section C402.4.5.1 as C403.2.4.4.1 and C402.4.5.2 as C403.2.4.4.1; add Section C403.3.1.1.5 as follows:

C402.4.5 Air intakes, exhaust openings, stairways and shafts. Stairway enclosures and elevator shaft vents and other outdoor air intakes and exhaust openings integral to the building envelope shall be provided with dampers in accordance with Section C403.2.4.4G402.4.5.1 and G402.4.5.2.

C403.2.4.4 Shutoff dampers.-controls. Both outdoor air supply and exhaust ducts shall be equipped with motorized dampers that will automatically shut when the systems or spaces served are not in use.

Exceptions:

1. Gravity dampers shall be permitted in buildings less than three stories in height. z. Gravity dampers shall be permitted for buildings of any height located in Climate Zones 1,2 and 3.

3. Gravity dampers shall be permitted for outside air intake or exhaust airflows of 300 efm $(0.14 \mathrm{~m} 3 / \mathrm{s})$ or less.

Stairway and shaft vent dampers shall meet the requirements of C403.2.4.4.1 and outdoor air intakes and exhausts shall meet the requirements of C403.2.4.4.2.

6402.4.5.1 C403.2.4.4.1 Stairway and shaft vent dampers. Stairway and shaft vents shall be provided with Class I motorized dampers with a maximum leakage rate of $4 \mathrm{cfm} / \mathrm{ft}^{2}(20.3 \mathrm{~L} / \mathrm{s}$. $\mathrm{m}^{2}$ ) at 1.0 inch water gauge (w.g.) (249 Pa) when tested in accordance with AMCA 500D. Stairway and shaft vent dampers shall be installed with controls so that they are capable of automatically opening upon:

1. The activation of any fire alarm initiating device of the building's fire alarm system; or

2. The interruption of power to the damper.

6402.4.5.2 C403.2.4.4.2 Outdoor air intakes and exhausts. Outdoor air supply and exhaust openings in the building thermal envelope, ducts, or equipment shall be provided with Class I $\mathrm{IA}$ motorized dampers with a maximum leakage rate of $4 \mathrm{cfm} / \mathrm{ft}^{2}\left(20.3 \mathrm{~L} / \mathrm{s} \cdot \mathrm{m}^{2}\right)$ at 1.0 inch water gauge (w.g.) (249 Pa) when tested in accordance with AMCA 500D. Outdoor air supply and exhaust motorized dampers shall be configured to automatically close when the systems or spaces served are not in use.

\section{Exceptions:}

1. Gravity (nonmotorized) dampers having a maximum leakage rate of $20 \mathrm{cfm} / \mathrm{ft}^{2}(101.6 \mathrm{~L} / \mathrm{s}$

$\cdot \mathrm{m}^{2}$ ) at 1.0 inch water gauge (w.g.) (249 Pa) when tested in accordance with AMCA

500D are permitted to be used as follows:

1.1. In buildings less than three stories in height above grade for exhaust and relief dampers.

1.2. In buildings less than three stories in height above grade.

1.3. For ventilation air intakes and exhaust and relief dampers in buildings of any height located in climate zones 1,2 and 3.

1.34. Where the design outdoor air intake or exhaust capacity does not exceed 300 cfm $(141 \mathrm{~L} / \mathrm{s})$.

Gravity (nonmotorized) dampers for ventilation air intakes shall be protected from direct exposure to wind.

2. Gravity (nonmotorized) dampers smaller than 24 inches $(610 \mathrm{~mm})$ in either dimension shall be permitted to have a leakage of $40 \mathrm{cfm} / \mathrm{ft}^{2}\left(203.2 \mathrm{~L} / \mathrm{s} \cdot \mathrm{m}^{2}\right)$ at 1.0 inch water gauge (w.g.) (249 Pa) when tested in accordance with AMCA 500D. 
3. Dampers are not required for:

3.1. Ventilation or exhaust systems serving unconditioned spaces.

3.2. Exhaust systems serving Type 1 kitchen exhaust hoods.

C403.3.1.1.5 Dampers. Exhaust/relief and outdoor air dampers shall meet the requirements of Section C403.2.4.4.2,

\section{B.1.3 Economizer and Fan Speed Controls}

\section{Purpose:}

- Fan Speed Controls. Reduce the system capacity threshold at which variable-speed drives are required for variable-flow systems saves significant fan energy

- Single Zone VAV. Require single zone systems with cooling capacities greater than 110,000 Btuh to use either variable-speed drives or multi-speed fan motors to reduce air flow, saving both fan and cooling energy.

- Economizer Improvements. Current economizer language in IECC is ambiguous regarding economizer requirements for complex systems. The changes make it clear that complex systems require air-side economizers. Energy is saved by reducing the amount of mechanical cooling required to maintain comfort conditions.

\section{Specific Amendment to 2012 IECC:}

Revise Sections C403.3.1, C403.4.1 and C403.4.2; add new Section C403.3.3; renumber and revise Section C403.4.2.1 as follows:

C403.3.1 Economizers. Each cooling system that has a fan shall include either an air or water economizer meeting the requirements of Sections C403.3.1.1 through C403.3.1.1.4.

C403.3.3 Fan airflow control. All air-conditioning equipment and air-handling units with direct expansion cooling and a cooling capacity of at least $110,000 \mathrm{Btu} / \mathrm{h}$ that serve single zones shall have their supply fans controlled by multi-speed motors or variable-speed drives. The supply fan controls shall be configured to reduce the airflow to no more than the larger of the following at cooling demands no larger than $50 \%$ of the cooling capacity:

1. Two-thirds of the full fan speed, or

2. The volume of outdoor air required to meet the ventilation requirements of the International Mechanical Code.

C403.4.1 Economizers. Each cooling system with a fan shall meet the provisions of Sections C403.3.1. and C403.4.1.4 for air Eeconomizers or shall comply with Sections C403.4.1.1 through C403.4.1.4 for water economizers.

C403.4.2 Fan airflow control. HVAC systems with fans shall meet the requirements of Sections C403.3.3 or C403.4.2.1.

C403.4.2.1 Variable-air-volume (VAV) fan control. Individual VAV fans with motors of $7.5 \underline{5}$ horsepower (5.6 $3.7 \mathrm{~kW})$ or greater shall be:

1. Driven by a mechanical or electrical variable-speed drive;

2. Driven by a vane-axial fan with variable-pitch blades; or

3. The fan shall have controls or devices that will result in fan motor demand of no more than 30 percent of their design wattage at 50 percent of design airflow when static pressure set point equals one-third of the total design static pressure, based on manufacturer's certified fan data. 


\section{B.1.4 Multiple-Zone VAV Reheat System Improvement}

Purpose:

Variable-air-volume (VAV) systems with reheat can benefit from multiple system improvements:

- Multiple-Zone Minimum Airflow Adjustment. This additional exception allows the designer to increase zone minimum airflow above code requirements when it will result in a reduction in overall ventilation air. Energy is saved by reducing excess outside air, resulting in reduced heating and cooling.

- Ventilation Efficiency Optimization. Ventilation optimization is an automated control procedure that allows reduction in VAV fan main ventilation airflow when critical zones are receiving higher than minimum zone airflow to maintain thermal conditions. Energy is saved by significantly reducing excess outside air, resulting in reduced heating and cooling.

- VAV for Zones with Special Pressurization Requirements. This amendment removes a blanket exception for VAV in zones where special pressure relationships are maintained and replaces it with a minimum airflow allowance to meet other codes or accreditation standards. Energy is saved by significantly reducing total airflow and reducing reheat required to maintain comfort conditions; this reduces heating, cooling, and fan energy.

\section{Specific Amendment to 2012 IECC:}

\section{Revise C403.4.5 and add C403.4.5.5 as follows:}

C403.4.5 Requirements for complex mechanical systems serving multiple zones. Sections C403.4.5.1 through C403.4.5.3 shall apply to complex mechanical systems serving multiple zones. Supply air systems serving multiple zones shall be VAV systems which, during periods of occupancy, are designed and capable of being controlled to reduce primary air supply to each zone to one of the following before reheating, recooling or mixing takes place:

1. Thirty percent of the maximum supply air to each zone.

2. Three hundred cfm $(142 \mathrm{~L} / \mathrm{s})$ or less where the maximum flow rate is less than 10 percent of the total fan system supply airflow rate.

3. The minimum ventilation requirements of Chapter 4 of the International Mechanical Code.

4. Any rate that can be demonstrated to reduce overall system annual energy use by offsetting reheat/recool energy losses through a reduction in outdoor air intake for the system, as approved by the code official.

5. The airflow rate required to comply with applicable codes or accreditation standards, such as pressure relationships or minimum air change rates.

Exception: The following define where individual zones or where entire air distribution systems are exempted from the requirement for VAV control:

1. Zones where special pressurization relationships or cross contamination requirements are such that VAV systems are impractical.

(Renumber remaining exceptions from 2-6 to 1-5)

C403.4.5.5 Multiple-zone VAV system ventilation optimization control. Multiple-zone VAV systems with direct digital control (DDC) of individual zone boxes reporting to a central control panel shall have automatic controls configured to reduce outdoor air intake flow below design rates in response to changes in system ventilation efficiency $\left(E_{v}\right)$ as defined by the International Mechanical Code. 


\section{Exceptions:}

1. VAV systems with zonal transfer fans that recirculate air from other zones without directly mixing it with outdoor air, dual-duct dual-fan VAV systems, and VAV systems with fan-powered terminal units.

2. Systems having exhaust air energy recovery complying with Section C403.2.6.

3. Systems where total design exhaust airflow is no less than $70 \%$ of the required total design outdoor air intake flow.

\section{B.1.5 Exterior Lighting Controls}

\section{Purpose:}

Add provisions so lighting for parking areas is controlled to reduce lighting power by $30 \%$ when unoccupied for over 15 minutes. Energy is saved by significantly reducing parking lot lighting operation, hence reducing lighting energy.

\section{Specific Amendment to 2012 IECC:}

Delete Section C405.2.4 and replace as follows:

C405.2.4 Exterior lighting controls. All exterior lighting shall be-provided with a control that automatically turns off the lighting when daylight is available.

Where lighting the building façade or landscape, the lighting shall also be provided with controls that automatically shut off the lighting from 12 midnight or within one hour of the end of business operations, whichever is later until 6 a.m. or business opening whichever is earlier.

Exterior lighting other than building façade or landscape lighting shall be provided with controls configured to automatically reduce the connected lighting power by at least 30 percent from 12 midnight or within one hour of the end of business operations, whichever is later until 6 a.m. or business opening whichever is earlier or during any period when no activity has been detected for a time of no longer than $\underline{15 \text { minutes. }}$

All controls that operate as a function of time shall be capable of retaining programming and the time setting during a loss of power of at least 10 hours.

\section{Exceptions:}

1. Emergency lighting that is intended to be automatically off during building operation.

2. Lighting specifically required to satisfy health and life safety requirements.

3. Decorative gas lighting systems

4. Lighting for covered vehicle entrances or exits from buildings or parking structures where required for safety, security, or eye adaptation. 
Table B.1. Site Energy Savings and Energy Cost Savings for the 2012 IECC with Amendments and Standard 90.12010 by Prototype (with Plugand-Process Loads)

\begin{tabular}{|c|c|c|c|c|c|c|}
\hline \multirow[b]{2}{*}{ Building Prototype } & \multicolumn{3}{|c|}{ Site Energy Use } & \multicolumn{3}{|c|}{ Site Energy Cost } \\
\hline & $\begin{array}{c}\text { Standard 90.1- } \\
2010 \\
\left(\mathrm{kBtu} / \mathrm{ft}^{2} / \mathrm{yr}\right)\end{array}$ & $\begin{array}{l}2012 \text { IECC } \\
\text { with } \\
\text { amendments } \\
\left(\mathrm{kBtu} / \mathrm{ft}^{2} / \mathrm{yr}\right)\end{array}$ & $\begin{array}{l}\text { 2012 IECC with } \\
\text { amendments } \\
\text { compared to } 90.1 \\
2010(\%)\end{array}$ & $\begin{array}{l}\text { Standard 90.1-2010 } \\
\text { Cost }\left(\$ / \mathrm{ft}^{2} / \mathrm{yr}\right)\end{array}$ & $\begin{array}{l}2012 \text { IECC with } \\
\text { amendments } \\
\text { Cost }\left(\$ / \mathrm{ft}^{2} / \mathrm{yr}\right)\end{array}$ & $\begin{array}{l}\text { 2012 IECC with } \\
\text { amendments } \\
\text { compared to } \\
90.12010 \text { (\%) }\end{array}$ \\
\hline Small Office & 30.5 & 29.5 & 3.5 & $\$ 0.91$ & $\$ 0.88$ & 3.4 \\
\hline Medium Office & 36.0 & 34.8 & 3.2 & $\$ 1.02$ & $\$ 0.98$ & 3.4 \\
\hline Large Office & 72.0 & 74.4 & -3.3 & $\$ 2.09$ & $\$ 2.19$ & -4.5 \\
\hline Stand-alone retail & 52.8 & 48.9 & 7.3 & $\$ 1.37$ & $\$ 1.31$ & 4.4 \\
\hline Strip Mall & 56.0 & 53.8 & 3.9 & $\$ 1.44$ & $\$ 1.39$ & 3.2 \\
\hline Primary School & 54.8 & 61.8 & -12.9 & $\$ 1.43$ & $\$ 1.53$ & -7.0 \\
\hline Secondary School & 46.3 & 47.9 & -3.3 & $\$ 1.26$ & $\$ 1.32$ & -4.7 \\
\hline Outpatient Healthcare & 124.2 & 126.1 & -1.6 & $\$ 3.20$ & $\$ 3.30$ & -3.1 \\
\hline Hospital & 130.7 & 133.5 & -2.2 & $\$ 3.13$ & $\$ 3.24$ & -3.6 \\
\hline Small Hotel & 63.3 & 66.1 & -4.5 & $\$ 1.44$ & $\$ 1.53$ & -6.4 \\
\hline Large Hotel & 94.3 & 98.2 & -4.1 & $\$ 2.10$ & $\$ 2.22$ & -5.6 \\
\hline Warehouse & 18.2 & 14.7 & 19.4 & $\$ 0.42$ & $\$ 0.34$ & 18.6 \\
\hline Quick Service Restaurant & 586.6 & 600.5 & -2.4 & $\$ 10.17$ & $\$ 10.36$ & -1.9 \\
\hline Full Service Restaurant & 385.2 & 405.5 & -5.3 & $\$ 7.36$ & $\$ 7.69$ & -4.5 \\
\hline Mid-rise Apartment & 45.7 & 44.3 & 3.0 & $\$ 1.26$ & $\$ 1.22$ & 3.1 \\
\hline High-rise Apartment & 52.9 & 51.1 & 3.4 & $\$ 1.29$ & $\$ 1.24$ & 3.8 \\
\hline National Weighted Average & 57.9 & 57.4 & 0.8 & $\$ 1.44$ & $\$ 1.43$ & 0.2 \\
\hline
\end{tabular}


Table B.2. Site Energy Savings and Energy Cost Savings for the 2012 IECC with Amendments and Standard 90.12010 by Climate Zone (with Plug-and-Process Loads)

\begin{tabular}{|c|c|c|c|c|c|c|c|}
\hline \multirow[b]{2}{*}{ Climate Zone } & \multirow[b]{2}{*}{ Representative City } & \multicolumn{3}{|c|}{ Site Energy Use } & \multicolumn{3}{|c|}{ Site Energy Cost } \\
\hline & & $\begin{array}{l}\text { Standard 90.1- } \\
2010 \\
\left(\mathrm{kBtu} / \mathrm{ft}^{2} / \mathrm{yr}\right)\end{array}$ & $\begin{array}{l}2012 \text { IECC with } \\
\text { Amendments } \\
\left(\mathrm{kBtu} / \mathrm{ft}^{2} / \mathrm{yr}\right)\end{array}$ & $\begin{array}{l}2012 \text { IECC with } \\
\text { Amendments } \\
\text { Compared to } 90.1 \\
2010(\%)\end{array}$ & $\begin{array}{l}\text { Standard 90.1- } \\
2010 \\
\text { Cost }(\$ / \mathrm{ft} 2 / \mathrm{yr})\end{array}$ & $\begin{array}{l}2012 \text { IECC with } \\
\text { Amendments } \\
\text { Cost }\left(\$ / \mathrm{ft}^{2} / \mathrm{yr}\right)\end{array}$ & $\begin{array}{l}2012 \text { IECC with } \\
\text { Amendments } \\
\text { Compared to } 90.1 \\
2010(\%)\end{array}$ \\
\hline $1 \mathrm{~A}$ & Miami & 53.9 & 51.9 & 3.8 & 1.48 & 1.42 & 4.2 \\
\hline $2 \mathrm{~A}$ & Houston & 55.5 & 54.6 & 1.7 & 1.46 & 1.44 & 1.6 \\
\hline $2 B$ & Phoenix & 56.4 & 55.0 & 2.5 & 1.53 & 1.48 & 2.8 \\
\hline $3 \mathrm{~A}$ & Memphis & 54.8 & 55.1 & -0.4 & 1.40 & 1.41 & -0.6 \\
\hline $3 B$ & El Paso & 50.6 & 50.7 & -0.2 & 1.32 & 1.33 & -0.3 \\
\hline $3 \mathrm{C}$ & San Francisco & 47.8 & 48.2 & -0.8 & 1.23 & 1.24 & -1.0 \\
\hline $4 \mathrm{~A}$ & Baltimore & 59.2 & 58.7 & 0.8 & 1.44 & 1.45 & -0.6 \\
\hline $4 \mathrm{~B}$ & Albuquerque & 60.4 & 60.4 & 0.1 & 1.49 & 1.50 & -0.4 \\
\hline $4 \mathrm{C}$ & Salem & 54.0 & 53.7 & 0.7 & 1.32 & 1.32 & -0.1 \\
\hline $5 \mathrm{~A}$ & Chicago & 62.7 & 62.4 & 0.6 & 1.46 & 1.46 & -0.4 \\
\hline $5 B$ & Boise & 59.8 & 59.1 & 1.1 & 1.43 & 1.43 & 0.1 \\
\hline $6 \mathrm{~A}$ & Burlington & 70.0 & 69.0 & 1.5 & 1.60 & 1.59 & 0.6 \\
\hline $6 \mathrm{~B}$ & Helena & 67.0 & 65.8 & 1.8 & 1.54 & 1.54 & 0.0 \\
\hline 7 & Duluth & 77.6 & 76.2 & 1.8 & 1.69 & 1.68 & 0.3 \\
\hline 8 & Fairbanks & 88.4 & 83.9 & 5.0 & 1.73 & 1.68 & 3.2 \\
\hline \multicolumn{2}{|c|}{ National Weighted Average } & 57.9 & 57.8 & 0.0 & 1.44 & 1.43 & 0.2 \\
\hline
\end{tabular}




\section{Appendix C}

Energy Savings Attributable to the IECC and Standard 90.1 by Building Type and End-Use Category 


\section{Appendix C}

\section{Energy Savings Attributable to the IECC and Standard 90.1 by Building Type and End-Use Category}

Table C.1. EUI by Prototype and Energy End-Use Category for Standard 90.12004 and the 2006 IECC

\begin{tabular}{|c|c|c|c|c|c|c|c|c|c|c|c|c|c|c|c|c|c|c|c|c|c|}
\hline \multirow[b]{2}{*}{ Prototype Name } & \multicolumn{2}{|c|}{$\begin{array}{c}\text { Interior Lights } \\
\left(\mathrm{kBtu} / \mathrm{ft}^{2} / \mathrm{yr}\right)\end{array}$} & \multicolumn{2}{|c|}{$\begin{array}{l}\text { Exterior Lights } \\
\left(\mathrm{kBtu} / \mathrm{ft}^{2} / \mathrm{yr}\right)\end{array}$} & \multicolumn{2}{|c|}{$\begin{array}{l}\text { Plug Loads } \\
\left(\mathrm{kBtu} / \mathrm{ft}^{2} / \mathrm{yr}\right)\end{array}$} & \multicolumn{2}{|c|}{$\begin{array}{c}\text { Fans } \\
\left(\mathrm{kBtu} / \mathrm{ft}^{2} / \mathrm{yr}\right)\end{array}$} & \multicolumn{2}{|c|}{$\begin{array}{c}\text { Pumps } \\
\left(\mathrm{kBtu} / \mathrm{ft}^{2} / \mathrm{yr}\right)\end{array}$} & \multicolumn{2}{|c|}{$\begin{array}{c}\text { Cooling } \\
\left(\mathrm{kBtu} / \mathrm{ft}^{2} / \mathrm{yr}\right)\end{array}$} & \multicolumn{2}{|c|}{$\begin{array}{c}\text { Heating } \\
\left(\mathrm{kBtu} / \mathrm{ft}^{2} / \mathrm{yr}\right)\end{array}$} & \multicolumn{2}{|c|}{$\begin{array}{c}\mathrm{SWH} \\
\left(\mathrm{kBtu} / \mathrm{ft}^{2} / \mathrm{yr}\right)\end{array}$} & \multicolumn{2}{|c|}{$\begin{array}{c}\text { Others }^{(\mathrm{a})} \\
\left(\mathrm{kBtu} / \mathrm{ft}^{2} / \mathrm{yr}\right)\end{array}$} & \multicolumn{2}{|c|}{$\begin{array}{c}\text { Total } \\
\left(\mathrm{kBtu} / \mathrm{ft}^{2} / \mathrm{yr}\right)\end{array}$} & \multirow{2}{*}{ 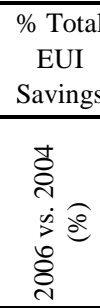 } \\
\hline & $\begin{array}{l}\text { ¿े } \\
\stackrel{1}{1} \\
\stackrel{1}{\circ} \\
8\end{array}$ & 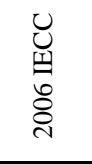 & $\begin{array}{l}\text { षे } \\
\stackrel{1}{1} \\
\stackrel{1}{\circ} \\
8\end{array}$ & 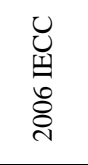 & $\begin{array}{l}+ \\
\stackrel{0}{1} \\
\stackrel{1}{\circ} \\
8\end{array}$ & 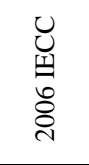 & $\begin{array}{l}+ \\
\stackrel{8}{\circ} \\
\stackrel{1}{1} \\
\stackrel{8}{8}\end{array}$ & 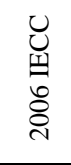 & $\begin{array}{l}\text { ¿े } \\
\stackrel{1}{1} \\
\stackrel{1}{\circ} \\
8\end{array}$ & 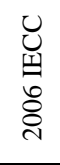 & $\begin{array}{l}\text { ¿े } \\
\stackrel{2}{1} \\
\stackrel{1}{\circ} \\
8\end{array}$ & 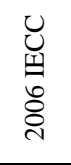 & $\begin{array}{l}\text { षे. } \\
\stackrel{1}{1} \\
\stackrel{1}{\circ} \\
8\end{array}$ & 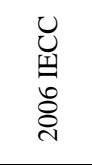 & $\begin{array}{l}\text { ¿े } \\
\stackrel{N}{1} \\
\stackrel{1}{1} \\
\dot{8}\end{array}$ & 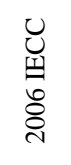 & $\begin{array}{l}\text { d } \\
\stackrel{2}{1} \\
\stackrel{1}{\circ} \\
8\end{array}$ & 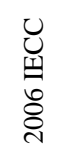 & $\begin{array}{l}\text { dे } \\
\stackrel{1}{1} \\
\stackrel{1}{\circ} \\
8\end{array}$ & 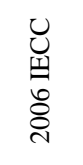 & \\
\hline Small Office & 12.2 & 12.5 & 4.4 & 4.4 & 9.1 & 9.1 & 4.4 & 4.4 & 0.0 & 0.0 & 5.1 & 5.2 & 2.5 & 2.3 & 2.0 & 3.6 & 0.0 & 0.0 & 39.8 & 41.5 & -4.3 \\
\hline Medium Office & 9.8 & 9.9 & 4.0 & 4.0 & 15.0 & 15.0 & 2.1 & 2.1 & 0.0 & 0.0 & 8.3 & 8.3 & 8.9 & 10.2 & 1.3 & 1.3 & 0.0 & 0.0 & 49.4 & 50.8 & -2.8 \\
\hline Large Office & 9.8 & 9.8 & 1.9 & 1.9 & 43.5 & 43.5 & 4.7 & 4.7 & 2.0 & 2.1 & 14.0 & 14.2 & 7.3 & 10.0 & 1.0 & 1.0 & 0.2 & 0.2 & 84.4 & 87.4 & -3.6 \\
\hline Stand-Alone Retail & 18.8 & 18.2 & 4.4 & 4.4 & 7.5 & 7.5 & 15.0 & 14.6 & 0.0 & 0.0 & 10.7 & 10.4 & 18.5 & 18.3 & 2.6 & 3.8 & 0.0 & 0.0 & 77.5 & 77.2 & 0.4 \\
\hline Strip Mall & 24.1 & 27.0 & 6.1 & 6.1 & 5.4 & 5.4 & 10.8 & 10.9 & 0.0 & 0.0 & 11.4 & 11.6 & 19.9 & 18.5 & 2.3 & 3.0 & 0.0 & 0.0 & 80.1 & 82.6 & -3.2 \\
\hline Primary School & 15.5 & 15.7 & 1.1 & 1.1 & 22.2 & 22.2 & 7.2 & 7.3 & 0.0 & 0.0 & 11.8 & 11.1 & 14.5 & 13.2 & 1.9 & 1.8 & 2.6 & 3.6 & 76.7 & 76.0 & 0.9 \\
\hline Secondary School & 14.8 & 15.7 & 1.0 & 1.0 & 14.7 & 14.7 & 8.4 & 8.4 & 0.7 & 0.7 & 12.9 & 14.7 & 7.8 & 6.9 & 2.9 & 2.9 & 3.0 & 3.7 & 66.1 & 68.6 & -3.7 \\
\hline Outpatient Healthcare & 14.2 & 12.9 & 5.3 & 5.3 & 47.3 & 47.3 & 13.6 & 14.3 & 0.6 & 1.0 & 26.6 & 25.9 & 49.0 & 49.3 & 2.9 & 2.9 & 5.3 & 8.8 & 164.6 & 167.6 & -1.8 \\
\hline Hospital & 16.6 & 17.9 & 1.0 & 1.0 & 49.8 & 49.8 & 17.3 & 17.3 & 4.5 & 4.9 & 18.7 & 17.9 & 48.6 & 55.2 & 4.7 & 4.7 & 8.1 & 8.2 & 169.4 & 176.8 & -4.4 \\
\hline Small Hotel & 10.9 & 12.7 & 2.1 & 2.1 & 22.5 & 22.5 & 6.6 & 6.6 & 0.0 & 0.0 & 8.7 & 8.6 & 10.1 & 9.5 & 12.5 & 12.5 & 0.0 & 0.0 & 73.4 & 74.6 & -1.6 \\
\hline Large Hotel & 11.3 & 11.7 & 2.4 & 2.4 & 35.8 & 35.8 & 7.9 & 8.6 & 1.9 & 1.9 & 19.4 & 21.7 & 18.4 & 17.8 & 16.7 & 16.6 & 4.0 & 4.1 & 117.7 & 120.7 & -2.5 \\
\hline Warehouse & 8.8 & 8.7 & 2.2 & 2.2 & 2.5 & 2.5 & 0.7 & 1.2 & 0.0 & 0.0 & 0.6 & 0.6 & 10.3 & 9.2 & 0.4 & 0.3 & 0.0 & 0.0 & 25.5 & 24.7 & 3.2 \\
\hline Quick-Service Restaurant & 28.5 & 24.1 & 10.4 & 10.4 & 296.7 & 296.7 & 41.8 & 41.3 & 0.0 & 0.0 & 35.4 & 34.6 & 135.5 & 136.4 & 67.5 & 67.0 & 25.0 & 25.0 & 640.6 & 635.5 & 0.8 \\
\hline Full-Service Restaurant & 32.0 & 27.6 & 10.0 & 10.0 & 170.3 & 170.3 & 43.9 & 43.2 & 0.1 & 0.1 & 31.0 & 29.8 & 104.9 & 105.8 & 67.0 & 66.3 & 11.2 & 11.2 & 470.3 & 464.4 & 1.2 \\
\hline Mid-Rise Apartment & 2.8 & 3.0 & 2.0 & 2.0 & 14.5 & 14.5 & 6.7 & 6.8 & 0.0 & 0.0 & 5.8 & 5.7 & 9.1 & 9.5 & 10.7 & 10.5 & 0.0 & 0.0 & 51.7 & 52.2 & -1.0 \\
\hline High-Rise Apartment & 2.6 & 2.6 & 2.4 & 2.4 & 13.2 & 13.2 & 7.6 & 7.7 & 0.8 & 0.8 & 11.3 & 11.2 & 8.5 & 8.7 & 11.4 & 11.4 & 0.0 & 0.0 & 57.9 & 58.1 & -0.3 \\
\hline $\begin{array}{l}\text { National Weighted } \\
\text { Average }\end{array}$ & 12.4 & 12.6 & 3.0 & 3.0 & 18.4 & 18.4 & 8.2 & 8.3 & 0.5 & 0.5 & 10.3 & 10.5 & 15.9 & 15.9 & 5.2 & 5.5 & 1.4 & 1.7 & 75.3 & 76.3 & -1.3 \\
\hline $\begin{array}{l}\text { Percent Savings by Each } \\
\text { End-Use Category (\%) }\end{array}$ & \multicolumn{2}{|c|}{-1.5} & \multicolumn{2}{|c|}{0.0} & \multicolumn{2}{|c|}{0.0} & \multicolumn{2}{|c|}{-1.1} & \multicolumn{2}{|c|}{-7.3} & \multicolumn{2}{|c|}{-1.7} & \multicolumn{2}{|c|}{0.2} & \multicolumn{2}{|c|}{-5.3} & \multicolumn{2}{|c|}{-20.2} & \multicolumn{2}{|c|}{-1.3} & \\
\hline $\begin{array}{l}\text { EUI }=\text { Energy use inte } \\
\text { SWH }=\text { Service water } \\
\text { (a) "Others" end use categ }\end{array}$ & & & & & & & & & & & & & & & & & & & & & \\
\hline
\end{tabular}


Table C.2. EUI by Prototype and Energy Usage Category for Standard 90.12007 and the 2009 IECC

\begin{tabular}{|c|c|c|c|c|c|c|c|c|c|c|c|c|c|c|c|c|c|c|c|c|c|}
\hline \multirow[b]{2}{*}{ Prototype Name } & \multicolumn{2}{|c|}{$\begin{array}{c}\text { Interior Lights } \\
\left(\mathrm{kBtu} / \mathrm{ft}^{2} / \mathrm{yr}\right)\end{array}$} & \multicolumn{2}{|c|}{$\begin{array}{c}\text { Exterior Lights } \\
\left(\mathrm{kBtu} / \mathrm{ft}^{2} / \mathrm{yr}\right)\end{array}$} & \multicolumn{2}{|c|}{$\begin{array}{l}\text { Plug Loads } \\
\left(\mathrm{kBtu} / \mathrm{ft}^{2} / \mathrm{yr}\right)\end{array}$} & \multicolumn{2}{|c|}{$\begin{array}{c}\text { Fans } \\
\left(\mathrm{kBtu} / \mathrm{ft}^{2} / \mathrm{yr}\right)\end{array}$} & \multicolumn{2}{|c|}{$\begin{array}{c}\begin{array}{c}\text { Pumps } \\
\left(\mathrm{kBtu} / \mathrm{ft}^{2} / \mathrm{yr}\right)\end{array} \\
\end{array}$} & \multicolumn{2}{|c|}{$\begin{array}{c}\text { Cooling } \\
\left(\mathrm{kBtu} / \mathrm{ft}^{2} / \mathrm{yr}\right)\end{array}$} & \multicolumn{2}{|c|}{$\begin{array}{c}\begin{array}{c}\text { Heating } \\
\left(\mathrm{kBtu} / \mathrm{ft}^{2} / \mathrm{yr}\right)\end{array} \\
\end{array}$} & \multicolumn{2}{|c|}{$\begin{array}{c}\begin{array}{c}\mathrm{SWH} \\
\left(\mathrm{kBtu} / \mathrm{ft}^{2} / \mathrm{yr}\right)\end{array} \\
\end{array}$} & \multicolumn{2}{|c|}{$\begin{array}{c}\text { Others (a) } \\
\left(\mathrm{kBtu} / \mathrm{ft}^{2} / \mathrm{yr}\right)\end{array}$} & \multicolumn{2}{|c|}{$\begin{array}{c}\text { Total } \\
\left(\mathrm{kBtu} / \mathrm{ft}^{2} / \mathrm{yr}\right)\end{array}$} & \multirow{2}{*}{ 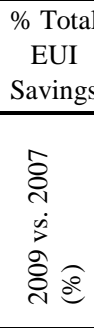 } \\
\hline & $\begin{array}{l}\hat{\delta} \\
\stackrel{\overbrace{}}{1} \\
\dot{8} \\
8\end{array}$ & 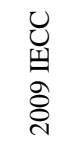 & $\begin{array}{l}\hat{0} \\
\stackrel{1}{1} \\
\dot{1} \\
\dot{8}\end{array}$ & 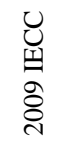 & $\begin{array}{l}\hat{\circ} \\
\text { 1े } \\
\stackrel{1}{8}\end{array}$ & 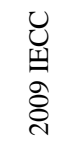 & $\begin{array}{l}\hat{o} \\
\stackrel{1}{1} \\
\stackrel{1}{8}\end{array}$ & 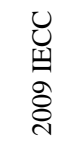 & $\begin{array}{l}\hat{0} \\
\stackrel{1}{1} \\
\stackrel{1}{8}\end{array}$ & 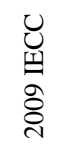 & $\begin{array}{l}\hat{0} \\
\stackrel{1}{1} \\
\dot{1} \\
\dot{8}\end{array}$ & 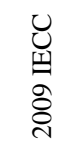 & $\begin{array}{l}\hat{0} \\
\stackrel{1}{1} \\
\dot{1} \\
\dot{8}\end{array}$ & 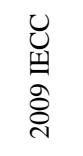 & $\begin{array}{l}\hat{0} \\
\stackrel{\circ}{1} \\
\stackrel{1}{\circ} \\
\text { ه }\end{array}$ & 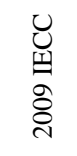 & $\begin{array}{l}\hat{0} \\
\stackrel{\circ}{1} \\
\dot{1} \\
\dot{8}\end{array}$ & 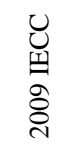 & $\begin{array}{l}\hat{0} \\
\stackrel{1}{1} \\
\stackrel{1}{0} \\
\text { \& }\end{array}$ & 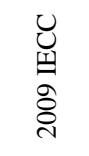 & \\
\hline Small Office & 12.2 & 12.5 & 4.4 & 2.5 & 9.1 & 9.1 & 4.2 & 4.2 & 0.0 & 0.0 & 4.0 & 4.1 & 1.7 & 1.8 & 2.0 & 3.6 & 0.0 & 0.0 & 37.7 & 37.8 & -0.1 \\
\hline Medium Office & 9.8 & 9.9 & 4.0 & 2.2 & 15.0 & 15.0 & 1.8 & 1.9 & 0.0 & 0.0 & 7.9 & 7.3 & 6.3 & 7.2 & 1.3 & 1.3 & 0.0 & 0.0 & 46.1 & 45.0 & 2.4 \\
\hline Large Office & 9.8 & 9.8 & 1.9 & 1.7 & 43.5 & 43.5 & 4.6 & 4.9 & 1.9 & 1.7 & 13.8 & 13.3 & 5.2 & 6.0 & 1.0 & 1.0 & 0.2 & 0.2 & 81.9 & 81.9 & -0.1 \\
\hline $\begin{array}{l}\text { Stand-Alone } \\
\text { Retail }\end{array}$ & 18.8 & 18.2 & 4.4 & 2.9 & 7.5 & 7.5 & 12.0 & 13.4 & 0.0 & 0.0 & 9.3 & 8.8 & 12.0 & 11.6 & 2.6 & 3.8 & 0.0 & 0.0 & 66.6 & 66.3 & 0.5 \\
\hline Strip Mall & 23.4 & 24.0 & 6.1 & 3.6 & 5.4 & 5.4 & 9.2 & 10.1 & 0.0 & 0.0 & 9.8 & 10.0 & 12.8 & 13.2 & 2.3 & 3.0 & 0.0 & 0.0 & 69.0 & 69.3 & -0.4 \\
\hline Primary School & 15.5 & 15.7 & 1.1 & 0.7 & 22.2 & 22.2 & 5.8 & 6.5 & 0.0 & 0.0 & 10.7 & 9.8 & 11.6 & 10.8 & 1.9 & 1.8 & 2.3 & 3.0 & 71.2 & 70.6 & 0.8 \\
\hline Secondary School & 14.8 & 15.7 & 1.0 & 0.6 & 14.7 & 14.7 & 6.5 & 7.3 & 0.6 & 0.7 & 11.7 & 11.8 & 5.0 & 4.3 & 2.9 & 2.9 & 2.2 & 2.7 & 59.4 & 60.5 & -1.9 \\
\hline $\begin{array}{l}\text { Outpatient } \\
\text { Healthcare }\end{array}$ & 14.2 & 12.9 & 5.3 & 3.0 & 47.3 & 47.3 & 12.3 & 13.0 & 0.6 & 0.8 & 25.5 & 23.9 & 42.7 & 42.4 & 2.9 & 2.9 & 4.2 & 6.1 & 154.9 & 152.3 & 1.7 \\
\hline Hospital & 16.6 & 17.9 & 1.0 & 0.8 & 49.8 & 49.8 & 16.7 & 17.6 & 4.6 & 5.7 & 18.5 & 19.5 & 51.7 & 56.1 & 4.7 & 4.7 & 8.1 & 8.8 & 171.7 & 180.8 & -5.3 \\
\hline Small Hotel & 10.9 & 12.7 & 2.1 & 1.4 & 22.5 & 22.5 & 6.5 & 6.6 & 0.0 & 0.0 & 8.1 & 8.3 & 5.2 & 5.1 & 12.5 & 12.5 & 0.0 & 0.0 & 67.8 & 69.1 & -1.9 \\
\hline Large Hotel & 11.3 & 11.7 & 2.4 & 1.8 & 35.8 & 35.8 & 6.7 & 9.9 & 1.8 & 1.8 & 19.7 & 18.1 & 28.0 & 14.2 & 16.7 & 16.6 & 0.6 & 4.3 & 122.8 & 114.3 & 6.9 \\
\hline Warehouse & 8.8 & 8.7 & 2.2 & 1.8 & 2.5 & 2.5 & 1.2 & 1.1 & 0.0 & 0.0 & 0.7 & 0.6 & 7.8 & 6.5 & 0.4 & 0.3 & 0.0 & 0.0 & 23.6 & 21.4 & 9.3 \\
\hline $\begin{array}{l}\text { Quick-Service } \\
\text { Restaurant }\end{array}$ & 28.5 & 24.1 & 10.4 & 6.9 & 296.7 & 296.7 & 39.4 & 40.1 & 0.0 & 0.0 & 35.3 & 34.0 & 121.2 & 128.6 & 67.5 & 67.0 & 24.9 & 24.9 & 623.7 & 622.3 & 0.2 \\
\hline $\begin{array}{l}\text { Full-Service } \\
\text { Restaurant }\end{array}$ & 32.0 & 27.6 & 10.0 & 6.7 & 170.3 & 170.3 & 35.3 & 34.4 & 0.1 & 0.1 & 29.8 & 28.0 & 83.9 & 86.2 & 67.0 & 66.4 & 11.0 & 11.0 & 439.4 & 430.5 & 2.0 \\
\hline $\begin{array}{l}\text { Mid-Rise } \\
\text { Apartment }\end{array}$ & 2.8 & 2.7 & 2.0 & 1.1 & 14.5 & 14.5 & 6.2 & 6.1 & 0.0 & 0.0 & 4.6 & 4.5 & 8.0 & 8.2 & 10.7 & 10.5 & 0.0 & 0.0 & 48.8 & 47.8 & 2.1 \\
\hline $\begin{array}{l}\text { High-Rise } \\
\text { Apartment }\end{array}$ & 2.6 & 2.3 & 2.4 & 1.8 & 13.2 & 13.2 & 7.2 & 7.2 & 0.8 & 0.8 & 11.1 & 11.0 & 7.6 & 7.8 & 11.4 & 11.4 & 0.0 & 0.0 & 56.3 & 55.5 & 1.5 \\
\hline $\begin{array}{l}\text { National } \\
\text { Weighted } \\
\text { Average }\end{array}$ & 12.3 & 12.3 & 3.0 & 2.0 & 18.4 & 18.4 & 7.1 & 7.7 & 0.5 & 0.5 & 9.6 & 9.3 & 13.3 & 12.5 & 5.2 & 5.5 & 1.1 & 1.4 & 70.5 & 69.7 & 1.1 \\
\hline $\begin{array}{l}\text { Percent Savings } \\
\text { by Each End-Use } \\
\text { Category (\%) } \\
\end{array}$ & \multicolumn{2}{|c|}{-0.0} & \multicolumn{2}{|c|}{34.3} & \multicolumn{2}{|c|}{0.0} & \multicolumn{2}{|c|}{-8.1} & \multicolumn{2}{|c|}{-8.2} & \multicolumn{2}{|c|}{3.1} & \multicolumn{2}{|c|}{5.6} & \multicolumn{2}{|c|}{-5.3} & \multicolumn{2}{|c|}{-35.8} & \multicolumn{2}{|c|}{1.1} & \\
\hline $\begin{array}{l}\text { EUI }=\text { Energy } \\
\text { SWH }=\text { Service } \\
\text { (a) "Others" end us }\end{array}$ & $\begin{array}{l}\text { use int } \\
\text { water l }\end{array}$ & ty. & 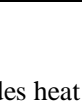 & & & & & & & & & & 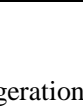 & & & & & & & & \\
\hline
\end{tabular}


Table C.3. Energy Use Intensity by Prototype and Energy Usage Category for ASHRAE Standard 90.12010 and the 2012 IECC

\begin{tabular}{|c|c|c|c|c|c|c|c|c|c|c|c|c|c|c|c|c|c|c|c|c|c|}
\hline \multirow[b]{2}{*}{ Prototype Name } & \multicolumn{2}{|c|}{$\begin{array}{l}\text { Interior Lights } \\
\left(\mathrm{kBtu} / \mathrm{ft}^{2} / \mathrm{yr}\right)\end{array}$} & \multicolumn{2}{|c|}{$\begin{array}{l}\text { Exterior Lights } \\
\left(\mathrm{kBtu} / \mathrm{ft}^{2} / \mathrm{yr}\right)\end{array}$} & \multicolumn{2}{|c|}{$\begin{array}{l}\text { Plug Loads } \\
\left(\mathrm{kBtu} / \mathrm{ft}^{2} / \mathrm{yr}\right)\end{array}$} & \multicolumn{2}{|c|}{$\begin{array}{c}\begin{array}{c}\text { Fans } \\
\left(\mathrm{kBtu} / \mathrm{ft}^{2} / \mathrm{yr}\right)\end{array} \\
\end{array}$} & \multicolumn{2}{|c|}{$\begin{array}{c}\begin{array}{c}\text { Pumps } \\
\left(\mathrm{kBtu} / \mathrm{ft}^{2} / \mathrm{yr}\right)\end{array} \\
\end{array}$} & \multicolumn{2}{|c|}{$\begin{array}{c}\text { Cooling } \\
\left(\mathrm{kBtu} / \mathrm{ft}^{2} / \mathrm{yr}\right)\end{array}$} & \multicolumn{2}{|c|}{$\begin{array}{c}\begin{array}{c}\text { Heating } \\
\left(\mathrm{kBtu} / \mathrm{ft}^{2} / \mathrm{yr}\right)\end{array} \\
\end{array}$} & \multicolumn{2}{|c|}{$\begin{array}{c}\mathrm{SWH} \\
\left(\mathrm{kBtu} / \mathrm{ft}^{2} / \mathrm{yr}\right)\end{array}$} & \multicolumn{2}{|c|}{$\begin{array}{c}\begin{array}{c}\text { Others } \\
(\mathrm{a}) \\
\left(\mathrm{kBtu} / \mathrm{ft}^{2} / \mathrm{yr}\right)\end{array} \\
\end{array}$} & \multicolumn{2}{|c|}{$\begin{array}{c}\text { Total } \\
\left(\mathrm{kBtu} / \mathrm{ft}^{2} / \mathrm{yr}\right)\end{array}$} & \multirow{2}{*}{ 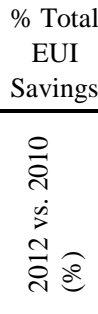 } \\
\hline & $\begin{array}{l}\circ \\
\stackrel{\circ}{1} \\
\stackrel{1}{1} \\
\text { \&̊ }\end{array}$ & 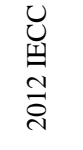 & $\begin{array}{l}\stackrel{\circ}{\circ} \\
\stackrel{1}{1} \\
\stackrel{-}{8}\end{array}$ & 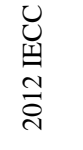 & $\begin{array}{l}\circ \\
\stackrel{\circ}{1} \\
\stackrel{1}{\circ} \\
\stackrel{8}{\circ}\end{array}$ & 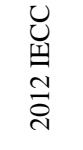 & $\begin{array}{l}\stackrel{0}{\circ} \\
\stackrel{2}{1} \\
\stackrel{1}{8}\end{array}$ & $\begin{array}{l}\text { U } \\
\text { II } \\
\text { Iี } \\
\text { ¿ }\end{array}$ & 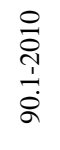 & 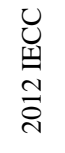 & $\begin{array}{l}0 \\
\stackrel{2}{1} \\
\stackrel{1}{8} \\
\text { \& }\end{array}$ & $\begin{array}{l}\text { U } \\
\text { ⿶1 } \\
\stackrel{\sim}{\Xi}\end{array}$ & $\begin{array}{l}\stackrel{0}{0} \\
\stackrel{2}{1} \\
\stackrel{1}{8} \\
\text { \& }\end{array}$ & 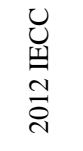 & 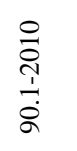 & $\begin{array}{l}\text { U } \\
\text { ⿶凵 } \\
\text { Iี } \\
\text { ָे }\end{array}$ & $\begin{array}{l}0 \\
\stackrel{\circ}{1} \\
\stackrel{1}{\circ} \\
\text { \& }\end{array}$ & 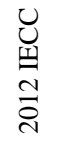 & 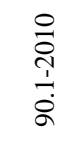 & 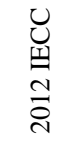 & \\
\hline Small Office & 9.5 & 8.5 & 1.6 & 2.5 & 8.4 & 9.1 & 3.9 & 3.6 & 0.0 & 0.0 & 3.7 & 3.5 & 1.5 & 1.4 & 1.9 & 1.9 & 0.0 & 0.0 & 30.5 & 30.5 & 0.0 \\
\hline Medium Office & 6.8 & 5.6 & 1.4 & 2.2 & 13.5 & 14.8 & 1.6 & 1.7 & 0.0 & 0.0 & 6.0 & 5.7 & 5.3 & 4.5 & 1.3 & 1.3 & 0.0 & 0.3 & 36.0 & 36.2 & -0.7 \\
\hline Large Office & 7.3 & 8.2 & 1.0 & 1.7 & 42.1 & 43.4 & 4.3 & 4.5 & 1.1 & 1.5 & 10.6 & 12.2 & 3.5 & 5.0 & 1.0 & 1.0 & 1.1 & 0.4 & 72.0 & 77.7 & -7.9 \\
\hline $\begin{array}{l}\text { Stand-Alone } \\
\text { Retail }\end{array}$ & 17.0 & 15.9 & 1.8 & 2.9 & 7.5 & 7.5 & 8.3 & 11.7 & 0.0 & 0.0 & 6.4 & 7.4 & 8.8 & 5.3 & 2.5 & 2.5 & 0.5 & 0.7 & 52.8 & 53.8 & -2.0 \\
\hline Strip Mall & 19.6 & 18.5 & 2.3 & 3.6 & 5.4 & 5.4 & 7.4 & 7.9 & 0.0 & 0.0 & 6.9 & 7.3 & 12.4 & 11.1 & 2.0 & 2.0 & 0.0 & 0.0 & 56.0 & 55.8 & 0.2 \\
\hline Primary School & 10.3 & 11.1 & 0.5 & 0.7 & 21.8 & 22.0 & 4.9 & 6.2 & 0.0 & 0.0 & 7.8 & 7.9 & 5.2 & 10.9 & 1.8 & 1.8 & 2.5 & 2.7 & 54.8 & 63.3 & -15.7 \\
\hline Secondary School & 9.6 & 11.2 & 0.4 & 0.6 & 14.3 & 14.5 & 5.1 & 6.5 & 0.2 & 0.6 & 9.0 & 9.7 & 2.6 & 2.7 & 2.9 & 2.9 & 2.3 & 2.6 & 46.3 & 51.2 & -10.6 \\
\hline $\begin{array}{l}\text { Outpatient } \\
\text { Healthcare }\end{array}$ & 12.2 & 10.4 & 3.0 & 3.0 & 46.5 & 47.3 & 9.2 & 14.6 & 0.6 & 0.9 & 18.6 & 21.6 & 28.2 & 39.1 & 2.9 & 2.9 & 3.0 & 8.1 & 124.2 & 147.9 & -19.1 \\
\hline Hospital & 14.3 & 16.0 & 0.8 & 0.8 & 49.3 & 49.5 & 11.4 & 18.0 & 2.5 & 5.7 & 13.5 & 17.4 & 27.8 & 53.7 & 4.7 & 4.7 & 6.4 & 7.6 & 130.7 & 173.4 & -32.7 \\
\hline Small Hotel & 8.9 & 11.4 & 1.4 & 1.4 & 22.2 & 22.5 & 6.1 & 6.4 & 0.0 & 0.0 & 7.0 & 7.5 & 5.1 & 4.4 & 12.5 & 12.5 & 0.0 & 0.0 & 63.3 & 66.2 & -4.6 \\
\hline Large Hotel & 10.6 & 10.9 & 1.8 & 1.8 & 35.4 & 35.6 & 5.7 & 9.7 & 0.6 & 1.7 & 14.3 & 16.8 & 7.0 & 11.7 & 16.6 & 16.6 & 2.2 & 4.3 & 94.3 & 109.3 & -15.9 \\
\hline Warehouse & 6.1 & 4.4 & 1.2 & 1.8 & 2.4 & 2.5 & 1.1 & 0.8 & 0.0 & 0.0 & 0.5 & 0.4 & 6.7 & 5.4 & 0.3 & 0.3 & 0.0 & 0.0 & 18.2 & 15.6 & 14.5 \\
\hline $\begin{array}{l}\text { Quick-Service } \\
\text { Restaurant }\end{array}$ & 13.2 & 14.5 & 4.4 & 6.9 & 296.5 & 296.7 & 29.2 & 38.4 & 0.0 & 0.0 & 25.5 & 28.8 & 125.5 & 131.9 & 67.4 & 67.4 & 24.9 & 24.9 & 586.6 & 609.5 & -3.9 \\
\hline $\begin{array}{l}\text { Full-Service } \\
\text { Restaurant }\end{array}$ & 13.2 & 14.6 & 4.3 & 6.7 & 169.2 & 170.3 & 23.2 & 30.3 & 0.1 & 0.1 & 20.4 & 23.5 & 77.2 & 89.2 & 66.6 & 66.6 & 11.0 & 11.0 & 385.2 & 412.2 & -7.0 \\
\hline $\begin{array}{l}\text { Mid-Rise } \\
\text { Apartment }\end{array}$ & 2.9 & 2.2 & 1.1 & 1.1 & 14.4 & 14.5 & 5.9 & 5.6 & 0.0 & 0.0 & 4.5 & 4.3 & 6.2 & 6.3 & 10.7 & 10.5 & 0.0 & 0.0 & 45.7 & 44.6 & 2.3 \\
\hline $\begin{array}{l}\text { High-Rise } \\
\text { Apartment }\end{array}$ & 2.9 & 2.1 & 1.8 & 1.8 & 12.9 & 13.0 & 6.9 & 6.5 & 0.6 & 0.8 & 11.1 & 10.8 & 5.0 & 5.1 & 11.4 & 11.4 & 0.0 & 0.0 & 52.9 & 51.5 & 2.7 \\
\hline $\begin{array}{l}\text { National } \\
\text { Weighted } \\
\text { Average }\end{array}$ & 9.8 & 9.3 & 1.5 & 2.0 & 18.0 & 18.3 & 5.7 & 7.1 & 0.3 & 0.5 & 7.4 & 8.1 & 9.0 & 10.2 & 5.1 & 5.1 & 1.2 & 1.6 & 57.9 & 62.1 & -7.4 \\
\hline $\begin{array}{l}\text { Percent Savings } \\
\text { by Each End- } \\
\text { Use Category } \\
\text { (\%) }\end{array}$ & \multicolumn{2}{|c|}{4.9} & \multicolumn{2}{|c|}{-35.7} & \multicolumn{2}{|c|}{-1.6} & \multicolumn{2}{|c|}{-24.9} & \multicolumn{2}{|c|}{-91.9} & \multicolumn{2}{|c|}{-8.9} & \multicolumn{2}{|c|}{-13.4} & \multicolumn{2}{|c|}{0.2} & \multicolumn{2}{|c|}{-37.5} & \multicolumn{2}{|c|}{-7.4} & \\
\hline $\begin{array}{l}\text { EUI = Energy } \\
\text { SWH }=\text { Service } \\
\text { (a) "Others" end us }\end{array}$ & use in & $\begin{array}{l}\text { ty. } \\
\text { ing. } \\
\text { incluc }\end{array}$ & & . & 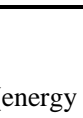 & 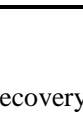 & & & & & & & 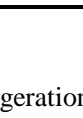 & & & & & & & & \\
\hline
\end{tabular}




\section{Appendix D}

\section{Energy and Energy Cost Comparison for 90.1-2010 and the}

2012 IECC by Climate Location and Building Type 


\section{Appendix D}

\section{Energy and Energy Cost Comparison for 90.1-2010 and the 2012 IECC by Climate Location and Building Type}

Table D.1. Energy and Energy Cost Comparison for the 2012 IECC and 90.1-2010 - Climate Zone 1A Miami

\begin{tabular}{|c|c|c|c|c|c|c|}
\hline & $90.1-2010$ & 2012 IECC & $90.1-2010$ & 2012 IECC & & \\
\hline Prototype Name & $\begin{array}{l}\text { Energy } \\
{[\mathrm{kBtu} / \mathrm{sf}]}\end{array}$ & $\begin{array}{l}\text { Site Energy } \\
{[\mathrm{kBtu} / \mathrm{sf}]}\end{array}$ & $\begin{array}{c}\text { Energy Cost } \\
{[\$ / \mathrm{sf}]}\end{array}$ & $\begin{array}{c}\text { Site Energy Cost } \\
{[\$ / \mathrm{sf}]}\end{array}$ & $\begin{array}{l}\text { Site Energy } \\
\text { Savings }\end{array}$ & $\begin{array}{l}\text { Energy Cost } \\
\text { Savings }\end{array}$ \\
\hline Small Office & 32.6 & 32.4 & $\$ 0.99$ & $\$ 0.98$ & $0.7 \%$ & $0.7 \%$ \\
\hline Medium Office & 38.1 & 38.4 & $\$ 1.13$ & $\$ 1.14$ & $-0.7 \%$ & $-0.6 \%$ \\
\hline Large Office & 76.4 & 81.8 & $\$ 2.29$ & $\$ 2.46$ & $-7.1 \%$ & $-7.3 \%$ \\
\hline Stand-Alone Retail & 51.0 & 53.7 & $\$ 1.49$ & $\$ 1.58$ & $-5.3 \%$ & $-6.0 \%$ \\
\hline Strip Mall & 51.8 & 52.4 & $\$ 1.56$ & $\$ 1.58$ & $-1.1 \%$ & $-1.3 \%$ \\
\hline Primary School & 58.6 & 60.7 & $\$ 1.65$ & $\$ 1.69$ & $-3.5 \%$ & $-2.6 \%$ \\
\hline Secondary School & 53.8 & 57.7 & $\$ 1.54$ & $\$ 1.66$ & $-7.3 \%$ & $-7.9 \%$ \\
\hline Outpatient Healthcare & 133.8 & 152.0 & $\$ 3.61$ & $\$ 4.00$ & $-13.6 \%$ & $-10.8 \%$ \\
\hline Hospital & 128.0 & 168.6 & $\$ 3.26$ & $\$ 4.13$ & $-31.7 \%$ & $-26.4 \%$ \\
\hline Small Hotel & 62.9 & 66.7 & $\$ 1.52$ & $\$ 1.64$ & $-6.0 \%$ & $-7.5 \%$ \\
\hline Large Hotel & 106.7 & 115.3 & $\$ 2.62$ & $\$ 2.89$ & $-8.1 \%$ & $-10.2 \%$ \\
\hline Warehouse & 12.1 & 9.9 & $\$ 0.37$ & $\$ 0.30$ & $18.6 \%$ & $18.5 \%$ \\
\hline Quick-Service Restaurant & 501.6 & 516.9 & $\$ 10.20$ & $\$ 10.65$ & $-3.1 \%$ & $-4.4 \%$ \\
\hline Full-Service Restaurant & 332.8 & 347.6 & $\$ 7.49$ & $\$ 7.92$ & $-4.5 \%$ & $-5.7 \%$ \\
\hline Mid-Rise Apartment & 43.5 & 40.9 & $\$ 1.31$ & $\$ 1.24$ & $5.8 \%$ & $5.8 \%$ \\
\hline High-Rise Apartment & 55.0 & 52.2 & $\$ 1.48$ & $\$ 1.39$ & $5.1 \%$ & $5.7 \%$ \\
\hline \multicolumn{7}{|l|}{ Totals } \\
\hline Climate Zone Weighted Average & 53.9 & 53.9 & $\$ 1.48$ & $\$ 1.47$ & $0.1 \%$ & $0.5 \%$ \\
\hline
\end{tabular}


Table D.2. Energy and Energy Cost Comparison for the 2012 IECC and 90.1-2010 - Climate Zone 2A Houston

\begin{tabular}{|c|c|c|c|c|c|c|}
\hline & $90.1-2010$ & 2012 IECC & $90.1-2010$ & 2012 IECC & & \\
\hline Prototype Name & $\begin{array}{l}\text { Site Energy } \\
{[\mathrm{kBtu} / \mathrm{sf}]}\end{array}$ & $\begin{array}{l}\text { Site Energy } \\
{[\mathrm{kBtu} / \mathrm{sf}]}\end{array}$ & $\begin{array}{c}\text { Site Energy Cost } \\
{[\$ / s f]}\end{array}$ & $\begin{array}{c}\text { Site Energy Cost } \\
{[\$ / s f]}\end{array}$ & $\begin{array}{l}\text { Site Energy } \\
\text { Savings }\end{array}$ & $\begin{array}{l}\text { Energy Cost } \\
\text { Savings }\end{array}$ \\
\hline Small Office & 31.4 & 31.3 & $\$ 0.95$ & $\$ 0.95$ & $0.2 \%$ & $0.2 \%$ \\
\hline Medium Office & 37.7 & 37.2 & $\$ 1.11$ & $\$ 1.08$ & $1.3 \%$ & $2.8 \%$ \\
\hline Large Office & 73.6 & 78.3 & $\$ 2.19$ & $\$ 2.32$ & $-6.3 \%$ & $-6.2 \%$ \\
\hline Stand-Alone Retail & 50.0 & 52.8 & $\$ 1.41$ & $\$ 1.51$ & $-5.6 \%$ & $-7.2 \%$ \\
\hline Strip Mall & 53.2 & 54.0 & $\$ 1.51$ & $\$ 1.55$ & $-1.5 \%$ & $-2.5 \%$ \\
\hline Primary School & 56.3 & 60.9 & $\$ 1.53$ & $\$ 1.61$ & $-8.1 \%$ & $-5.5 \%$ \\
\hline Secondary School & 51.1 & 54.1 & $\$ 1.42$ & $\$ 1.54$ & $-5.9 \%$ & $-7.8 \%$ \\
\hline Outpatient Healthcare & 131.0 & 148.8 & $\$ 3.49$ & $\$ 3.86$ & $-13.6 \%$ & $-10.7 \%$ \\
\hline Hospital & 129.8 & 168.3 & $\$ 3.21$ & $\$ 4.00$ & $-29.7 \%$ & $-24.7 \%$ \\
\hline Small Hotel & 61.9 & 65.3 & $\$ 1.46$ & $\$ 1.56$ & $-5.5 \%$ & $-7.3 \%$ \\
\hline Large Hotel & 100.7 & 112.1 & $\$ 2.35$ & $\$ 2.71$ & $-11.3 \%$ & $-15.0 \%$ \\
\hline Warehouse & 13.3 & 11.5 & $\$ 0.37$ & $\$ 0.31$ & $13.3 \%$ & $16.4 \%$ \\
\hline Quick-Service Restaurant & 532.0 & 546.3 & $\$ 10.11$ & $\$ 10.58$ & $-2.7 \%$ & $-4.7 \%$ \\
\hline Full-Service Restaurant & 347.4 & 366.0 & $\$ 7.29$ & $\$ 7.79$ & $-5.4 \%$ & $-6.8 \%$ \\
\hline Mid-Rise Apartment & 42.9 & 41.3 & $\$ 1.26$ & $\$ 1.21$ & $3.8 \%$ & $4.2 \%$ \\
\hline High-Rise Apartment & 51.9 & 49.7 & $\$ 1.33$ & $\$ 1.27$ & $4.1 \%$ & $5.1 \%$ \\
\hline \multicolumn{7}{|l|}{ Totals } \\
\hline Climate Zone Weighted Average & 55.5 & 58.6 & $\$ 1.46$ & $\$ 1.54$ & $-5.6 \%$ & $-5.1 \%$ \\
\hline
\end{tabular}


Table D.3. Energy and Energy Cost Comparison for the 2012 IECC and 90.1-2010 - Climate Zone 2B Phoenix

\begin{tabular}{|c|c|c|c|c|c|c|}
\hline & $90.1-2010$ & 2012 IECC & $90.1-2010$ & 2012 IECC & & \\
\hline Prototype Name & $\begin{array}{c}\text { Site Energy } \\
{[\mathrm{kBtu} / \mathrm{sf}]}\end{array}$ & $\begin{array}{c}\text { Site Energy } \\
{[\mathrm{kBtu} / \mathrm{sf}]}\end{array}$ & $\begin{array}{c}\text { Site Energy Cost } \\
{[\$ / \mathrm{sf}]}\end{array}$ & $\begin{array}{c}\text { Site Energy Cost } \\
{[\$ / \mathrm{sf}]}\end{array}$ & $\begin{array}{c}\text { Site Energy } \\
\text { Savings }\end{array}$ & $\begin{array}{c}\text { Energy Cost } \\
\text { Savings }\end{array}$ \\
\hline Small Office & 32.7 & 32.2 & $\$ 0.99$ & $\$ 0.97$ & $1.6 \%$ & $1.6 \%$ \\
\hline Medium Office & 38.0 & 37.6 & $\$ 1.12$ & $\$ 1.10$ & $1.0 \%$ & $1.7 \%$ \\
\hline Large Office & 76.2 & 78.3 & $\$ 2.28$ & $\$ 2.34$ & $-2.8 \%$ & $-2.7 \%$ \\
\hline Stand-Alone Retail & 53.2 & 54.6 & $\$ 1.51$ & $\$ 1.57$ & $-2.6 \%$ & $-4.2 \%$ \\
\hline Strip Mall & 54.1 & 54.8 & $\$ 1.60$ & $\$ 1.63$ & $-1.3 \%$ & $-2.0 \%$ \\
\hline Primary School & 56.8 & 60.9 & $\$ 1.57$ & $\$ 1.64$ & $-7.2 \%$ & $-4.2 \%$ \\
\hline Secondary School & 52.2 & 55.0 & $\$ 1.47$ & $\$ 1.57$ & $-5.5 \%$ & $-6.7 \%$ \\
\hline Outpatient Healthcare & 124.5 & 143.8 & $\$ 3.37$ & $\$ 3.81$ & $-15.5 \%$ & $-13.1 \%$ \\
\hline Hospital & 131.5 & 170.1 & $\$ 3.32$ & $\$ 4.12$ & $-29.4 \%$ & $-24.1 \%$ \\
\hline Small Hotel & 60.5 & 64.1 & $\$ 1.44$ & $\$ 1.55$ & $-5.9 \%$ & $-7.7 \%$ \\
\hline Large Hotel & 99.5 & 108.4 & $\$ 2.38$ & $\$ 2.63$ & $-9.0 \%$ & $-10.6 \%$ \\
\hline Warehouse & 17.3 & 14.0 & $\$ 0.50$ & $\$ 0.40$ & $19.2 \%$ & $20.5 \%$ \\
\hline Quick-Service Restaurant & 517.5 & 533.7 & $\$ 10.14$ & $\$ 10.68$ & $-3.1 \%$ & $-5.4 \%$ \\
\hline Full-Service Restaurant & 347.2 & 372.2 & $\$ 7.58$ & $\$ 8.32$ & $-7.2 \%$ & $-9.7 \%$ \\
\hline Mid-Rise Apartment & 43.7 & 41.4 & $\$ 1.31$ & $\$ 1.24$ & $5.2 \%$ & $5.3 \%$ \\
\hline High-Rise Apartment & 52.7 & 49.5 & $\$ 1.40$ & $\$ 1.30$ & $6.2 \%$ & $7.1 \%$ \\
\hline \multicolumn{7}{|l|}{ Totals } \\
\hline Climate Zone Weighted Average & 56.4 & 59.2 & $\$ 1.53$ & $\$ 1.59$ & $-4.9 \%$ & $-4.2 \%$ \\
\hline
\end{tabular}


Table D.4. Energy and Energy Cost Comparison for the 2012 IECC and 90.1-2010 - Climate Zone 3A Memphis

\begin{tabular}{|c|c|c|c|c|c|c|}
\hline & $90.1-2010$ & 2012 IECC & $90.1-2010$ & 2012 IECC & & \\
\hline Prototype Name & $\begin{array}{l}\text { Site Energy } \\
{[\mathrm{kBtu} / \mathrm{sf}]}\end{array}$ & $\begin{array}{l}\text { Site Energy } \\
{[\mathrm{kBtu} / \mathrm{sf}]}\end{array}$ & $\begin{array}{c}\text { Site Energy Cost } \\
{[\$ / s f]}\end{array}$ & $\begin{array}{c}\text { Site Energy Cost } \\
{[\$ / \mathrm{sf}]}\end{array}$ & $\begin{array}{l}\text { Site Energy } \\
\text { Savings }\end{array}$ & $\begin{array}{l}\text { Energy Cost } \\
\text { Savings }\end{array}$ \\
\hline Small Office & 30.2 & 30.3 & $\$ 0.91$ & $\$ 0.91$ & $-0.5 \%$ & $-0.5 \%$ \\
\hline Medium Office & 35.1 & 36.5 & $\$ 1.03$ & $\$ 1.04$ & $-4.0 \%$ & $-0.9 \%$ \\
\hline Large Office & 71.6 & 77.6 & $\$ 2.11$ & $\$ 2.26$ & $-8.5 \%$ & $-7.1 \%$ \\
\hline Stand-Alone Retail & 49.2 & 53.7 & $\$ 1.35$ & $\$ 1.51$ & $-9.1 \%$ & $-11.5 \%$ \\
\hline Strip Mall & 52.2 & 53.3 & $\$ 1.40$ & $\$ 1.45$ & $-2.1 \%$ & $-3.4 \%$ \\
\hline Primary School & 53.9 & 61.2 & $\$ 1.43$ & $\$ 1.56$ & $-13.5 \%$ & $-9.5 \%$ \\
\hline Secondary School & 47.2 & 51.5 & $\$ 1.30$ & $\$ 1.44$ & $-9.1 \%$ & $-10.3 \%$ \\
\hline Outpatient Healthcare & 126.1 & 146.3 & $\$ 3.33$ & $\$ 3.76$ & $-16.1 \%$ & $-13.2 \%$ \\
\hline Hospital & 129.3 & 170.2 & $\$ 3.14$ & $\$ 3.94$ & $-31.7 \%$ & $-25.6 \%$ \\
\hline Small Hotel & 61.5 & 65.1 & $\$ 1.42$ & $\$ 1.53$ & $-5.8 \%$ & $-7.8 \%$ \\
\hline Large Hotel & 96.7 & 110.2 & $\$ 2.19$ & $\$ 2.55$ & $-13.9 \%$ & $-16.8 \%$ \\
\hline Warehouse & 15.9 & 15.0 & $\$ 0.39$ & $\$ 0.36$ & $5.6 \%$ & $7.4 \%$ \\
\hline Quick-Service Restaurant & 564.0 & 576.7 & $\$ 10.11$ & $\$ 10.59$ & $-2.2 \%$ & $-4.7 \%$ \\
\hline Full-Service Restaurant & 363.8 & 385.7 & $\$ 7.20$ & $\$ 7.75$ & $-6.0 \%$ & $-7.7 \%$ \\
\hline Mid-Rise Apartment & 43.3 & 44.1 & $\$ 1.23$ & $\$ 1.22$ & $-1.9 \%$ & $1.0 \%$ \\
\hline High-Rise Apartment & 50.2 & 51.5 & $\$ 1.23$ & $\$ 1.24$ & $-2.5 \%$ & $-0.3 \%$ \\
\hline \multicolumn{7}{|l|}{ Totals } \\
\hline Climate Zone Weighted Average & 54.8 & 59.7 & $\$ 1.40$ & $\$ 1.52$ & $-9.0 \%$ & $-8.5 \%$ \\
\hline
\end{tabular}


Table D.5. Energy and Energy Cost Comparison for the 2012 IECC and 90.1-2010 - Climate Zone 3B El Paso

\begin{tabular}{|c|c|c|c|c|c|c|}
\hline & $90.1-2010$ & 2012 IECC & $90.1-2010$ & 2012 IECC & & \\
\hline Prototype Name & $\begin{array}{l}\text { Site Energy } \\
{[\mathrm{kBtu} / \mathrm{sf}]}\end{array}$ & $\begin{array}{l}\text { Site Energy } \\
{[\mathrm{kBtu} / \mathrm{sf}]}\end{array}$ & $\begin{array}{c}\text { Site Energy Cost } \\
{[\$ / \mathrm{sf}]}\end{array}$ & $\begin{array}{c}\text { Site Energy Cost } \\
{[\$ / \mathrm{sf}]}\end{array}$ & $\begin{array}{l}\text { Site Energy } \\
\text { Savings }\end{array}$ & $\begin{array}{l}\text { Energy Cost } \\
\text { Savings }\end{array}$ \\
\hline Small Office & 30.3 & 30.3 & $\$ 0.92$ & $\$ 0.92$ & $-0.1 \%$ & $0.0 \%$ \\
\hline Medium Office & 32.6 & 34.3 & $\$ 0.95$ & $\$ 0.99$ & $-5.1 \%$ & $-3.7 \%$ \\
\hline Large Office & 73.9 & 78.1 & $\$ 2.20$ & $\$ 2.33$ & $-5.7 \%$ & $-5.5 \%$ \\
\hline Stand-Alone Retail & 49.2 & 52.5 & $\$ 1.37$ & $\$ 1.51$ & $-6.7 \%$ & $-10.8 \%$ \\
\hline Strip Mall & 48.0 & 47.4 & $\$ 1.39$ & $\$ 1.39$ & $1.4 \%$ & $0.1 \%$ \\
\hline Primary School & 51.8 & 59.3 & $\$ 1.41$ & $\$ 1.55$ & $-14.6 \%$ & $-10.0 \%$ \\
\hline Secondary School & 44.6 & 49.8 & $\$ 1.25$ & $\$ 1.41$ & $-11.6 \%$ & $-12.4 \%$ \\
\hline Outpatient Healthcare & 118.4 & 139.7 & $\$ 3.23$ & $\$ 3.76$ & $-18.0 \%$ & $-16.4 \%$ \\
\hline Hospital & 124.3 & 157.6 & $\$ 3.13$ & $\$ 3.81$ & $-26.8 \%$ & $-21.7 \%$ \\
\hline Small Hotel & 59.3 & 62.8 & $\$ 1.37$ & $\$ 1.48$ & $-5.9 \%$ & $-7.8 \%$ \\
\hline Large Hotel & 91.1 & 101.1 & $\$ 2.11$ & $\$ 2.36$ & $-11.0 \%$ & $-11.8 \%$ \\
\hline Warehouse & 14.9 & 13.8 & $\$ 0.39$ & $\$ 0.36$ & $7.1 \%$ & $8.1 \%$ \\
\hline Quick-Service Restaurant & 526.1 & 545.6 & $\$ 9.67$ & $\$ 10.25$ & $-3.7 \%$ & $-6.0 \%$ \\
\hline Full-Service Restaurant & 347.0 & 373.4 & $\$ 7.19$ & $\$ 7.93$ & $-7.6 \%$ & $-10.3 \%$ \\
\hline Mid-Rise Apartment & 41.1 & 40.7 & $\$ 1.22$ & $\$ 1.19$ & $0.9 \%$ & $2.2 \%$ \\
\hline High-Rise Apartment & 47.7 & 47.3 & $\$ 1.21$ & $\$ 1.19$ & $0.8 \%$ & $2.0 \%$ \\
\hline \multicolumn{7}{|l|}{ Totals } \\
\hline Climate Zone Weighted Average & 50.6 & 54.2 & $\$ 1.32$ & $\$ 1.42$ & $-7.1 \%$ & $-7.0 \%$ \\
\hline
\end{tabular}


Table D.6. Energy and Energy Cost Comparison for the 2012 IECC and 90.1-2010 - Climate Zone 3C San Francisco

\begin{tabular}{|c|c|c|c|c|c|c|}
\hline & $90.1-2010$ & 2012 IECC & $90.1-2010$ & 2012 IECC & & \\
\hline Prototype Name & $\begin{array}{l}\text { Site Energy } \\
{[\mathrm{kBtu} / \mathrm{sf}]}\end{array}$ & $\begin{array}{l}\text { Site Energy } \\
{[\mathrm{kBtu} / \mathrm{sf}]}\end{array}$ & $\begin{array}{c}\text { Site Energy Cost } \\
{[\$ / s f]}\end{array}$ & $\begin{array}{c}\text { Site Energy Cost } \\
{[\$ / \mathrm{sf}]}\end{array}$ & $\begin{array}{l}\text { Site Energy } \\
\text { Savings }\end{array}$ & $\begin{array}{l}\text { Energy Cost } \\
\text { Savings }\end{array}$ \\
\hline Small Office & 26.5 & 26.8 & $\$ 0.80$ & $\$ 0.81$ & $-1.2 \%$ & $-1.2 \%$ \\
\hline Medium Office & 27.4 & 30.5 & $\$ 0.80$ & $\$ 0.84$ & $-11.4 \%$ & $-5.7 \%$ \\
\hline Large Office & 62.0 & 69.1 & $\$ 1.85$ & $\$ 2.04$ & $-11.5 \%$ & $-10.4 \%$ \\
\hline Stand-Alone Retail & 41.6 & 44.5 & $\$ 1.10$ & $\$ 1.22$ & $-7.1 \%$ & $-11.0 \%$ \\
\hline Strip Mall & 41.6 & 40.2 & $\$ 1.15$ & $\$ 1.14$ & $3.3 \%$ & $1.5 \%$ \\
\hline Primary School & 46.5 & 56.1 & $\$ 1.24$ & $\$ 1.39$ & $-20.8 \%$ & $-12.1 \%$ \\
\hline Secondary School & 38.2 & 42.1 & $\$ 1.04$ & $\$ 1.17$ & $-10.1 \%$ & $-11.8 \%$ \\
\hline Outpatient Healthcare & 106.5 & 129.5 & $\$ 2.73$ & $\$ 3.27$ & $-21.6 \%$ & $-19.9 \%$ \\
\hline Hospital & 116.4 & 152.9 & $\$ 2.75$ & $\$ 3.43$ & $-31.3 \%$ & $-24.7 \%$ \\
\hline Small Hotel & 56.7 & 59.6 & $\$ 1.26$ & $\$ 1.35$ & $-5.1 \%$ & $-7.1 \%$ \\
\hline Large Hotel & 82.2 & 88.7 & $\$ 1.77$ & $\$ 1.97$ & $-7.9 \%$ & $-11.4 \%$ \\
\hline Warehouse & 15.8 & 14.8 & $\$ 0.37$ & $\$ 0.35$ & $6.5 \%$ & $6.2 \%$ \\
\hline Quick-Service Restaurant & 511.5 & 516.4 & $\$ 8.97$ & $\$ 9.10$ & $-1.0 \%$ & $-1.6 \%$ \\
\hline Full-Service Restaurant & 331.3 & 341.6 & $\$ 6.45$ & $\$ 6.67$ & $-3.1 \%$ & $-3.4 \%$ \\
\hline Mid-Rise Apartment & 36.9 & 36.8 & $\$ 1.09$ & $\$ 1.06$ & $0.3 \%$ & $2.5 \%$ \\
\hline High-Rise Apartment & 39.5 & 39.0 & $\$ 0.94$ & $\$ 0.90$ & $1.2 \%$ & $3.7 \%$ \\
\hline \multicolumn{7}{|l|}{ Totals } \\
\hline Climate Zone Weighted Average & 47.8 & 51.5 & $\$ 1.23$ & $\$ 1.32$ & $-7.8 \%$ & $-7.1 \%$ \\
\hline
\end{tabular}


Table D.7. Energy and Energy Cost Comparison for the 2012 IECC and 90.1-2010 - Climate Zone 4A Baltimore

\begin{tabular}{|c|c|c|c|c|c|c|}
\hline & $90.1-2010$ & 2012 IECC & $90.1-2010$ & 2012 IECC & & \\
\hline Prototype Name & $\begin{array}{l}\text { Site Energy } \\
{[\mathrm{kBtu} / \mathrm{sf}]}\end{array}$ & $\begin{array}{l}\text { Site Energy } \\
{[\mathrm{kBtu} / \mathrm{sf}]}\end{array}$ & $\begin{array}{c}\text { Site Energy Cost } \\
{[\$ / \mathrm{sf}]}\end{array}$ & $\begin{array}{c}\text { Site Energy Cost } \\
{[\$ / \mathrm{sf}]}\end{array}$ & $\begin{array}{l}\text { Site Energy } \\
\text { Savings }\end{array}$ & $\begin{array}{c}\text { Energy Cost } \\
\text { Savings }\end{array}$ \\
\hline Small Office & 29.8 & 29.6 & $\$ 0.89$ & $\$ 0.89$ & $0.6 \%$ & $0.7 \%$ \\
\hline Medium Office & 35.2 & 35.0 & $\$ 0.98$ & $\$ 0.99$ & $0.5 \%$ & $-0.8 \%$ \\
\hline Large Office & 71.4 & 77.6 & $\$ 2.07$ & $\$ 2.21$ & $-8.7 \%$ & $-6.9 \%$ \\
\hline Stand-Alone Retail & 57.2 & 53.2 & $\$ 1.38$ & $\$ 1.45$ & $7.0 \%$ & $-4.6 \%$ \\
\hline Strip Mall & 57.5 & 57.1 & $\$ 1.40$ & $\$ 1.43$ & $0.7 \%$ & $-1.8 \%$ \\
\hline Primary School & 53.9 & 64.7 & $\$ 1.38$ & $\$ 1.56$ & $-19.9 \%$ & $-12.6 \%$ \\
\hline Secondary School & 44.4 & 50.0 & $\$ 1.20$ & $\$ 1.36$ & $-12.7 \%$ & $-13.2 \%$ \\
\hline Outpatient Healthcare & 122.2 & 146.9 & $\$ 3.13$ & $\$ 3.70$ & $-20.2 \%$ & $-18.3 \%$ \\
\hline Hospital & 130.1 & 174.2 & $\$ 3.10$ & $\$ 3.92$ & $-33.9 \%$ & $-26.3 \%$ \\
\hline Small Hotel & 63.0 & 65.8 & $\$ 1.42$ & $\$ 1.52$ & $-4.5 \%$ & $-6.5 \%$ \\
\hline Large Hotel & 91.2 & 109.9 & $\$ 2.03$ & $\$ 2.45$ & $-20.5 \%$ & $-20.9 \%$ \\
\hline Warehouse & 19.5 & 16.2 & $\$ 0.42$ & $\$ 0.36$ & $17.0 \%$ & $13.3 \%$ \\
\hline Quick-Service Restaurant & 600.5 & 629.8 & $\$ 10.09$ & $\$ 10.77$ & $-4.9 \%$ & $-6.7 \%$ \\
\hline Full-Service Restaurant & 391.2 & 421.6 & $\$ 7.20$ & $\$ 7.85$ & $-7.7 \%$ & $-9.0 \%$ \\
\hline Mid-Rise Apartment & 46.8 & 45.6 & $\$ 1.26$ & $\$ 1.23$ & $2.6 \%$ & $2.6 \%$ \\
\hline High-Rise Apartment & 53.0 & 51.8 & $\$ 1.24$ & $\$ 1.21$ & $2.2 \%$ & $2.2 \%$ \\
\hline \multicolumn{7}{|l|}{ Totals } \\
\hline Climate Zone Weighted Average & 59.2 & 63.2 & $\$ 1.44$ & $\$ 1.55$ & $-6.7 \%$ & $-7.6 \%$ \\
\hline
\end{tabular}


Table D.8. Energy and Energy Cost Comparison for the 2012 IECC and 90.1-2010 - Climate Zone 4B Albuquerque

\begin{tabular}{|c|c|c|c|c|c|c|}
\hline & $90.1-2010$ & 2012 IECC & $90.1-2010$ & 2012 IECC & & \\
\hline Prototype Name & $\begin{array}{l}\text { Site Energy } \\
{[\mathrm{kBtu} / \mathrm{sf}]}\end{array}$ & $\begin{array}{l}\text { Site Energy } \\
{[\mathrm{kBtu} / \mathrm{sf}]}\end{array}$ & $\begin{array}{c}\text { Site Energy Cost } \\
{[\$ / \mathrm{sf}]}\end{array}$ & $\begin{array}{c}\text { Site Energy Cost } \\
{[\$ / \mathrm{sf}]}\end{array}$ & $\begin{array}{l}\text { Site Energy } \\
\text { Savings }\end{array}$ & $\begin{array}{l}\text { Energy Cost } \\
\text { Savings }\end{array}$ \\
\hline Small Office & 30.0 & 29.7 & $\$ 0.91$ & $\$ 0.89$ & $1.3 \%$ & $1.4 \%$ \\
\hline Medium Office & 32.2 & 34.0 & $\$ 0.93$ & $\$ 0.96$ & $-5.6 \%$ & $-3.2 \%$ \\
\hline Large Office & 73.1 & 78.6 & $\$ 2.16$ & $\$ 2.32$ & $-7.6 \%$ & $-7.4 \%$ \\
\hline Stand-Alone Retail & 51.0 & 52.7 & $\$ 1.34$ & $\$ 1.45$ & $-3.3 \%$ & $-7.9 \%$ \\
\hline Strip Mall & 49.3 & 48.5 & $\$ 1.37$ & $\$ 1.36$ & $1.6 \%$ & $0.6 \%$ \\
\hline Primary School & 51.0 & 61.2 & $\$ 1.36$ & $\$ 1.55$ & $-19.8 \%$ & $-13.5 \%$ \\
\hline Secondary School & 42.9 & 48.1 & $\$ 1.18$ & $\$ 1.34$ & $-12.1 \%$ & $-13.4 \%$ \\
\hline Outpatient Healthcare & 117.7 & 143.4 & $\$ 3.18$ & $\$ 3.68$ & $-21.9 \%$ & $-15.8 \%$ \\
\hline Hospital & 129.9 & 167.4 & $\$ 3.23$ & $\$ 3.95$ & $-28.9 \%$ & $-22.5 \%$ \\
\hline Small Hotel & 60.5 & 63.6 & $\$ 1.37$ & $\$ 1.47$ & $-5.2 \%$ & $-7.3 \%$ \\
\hline Large Hotel & 95.2 & 101.8 & $\$ 2.06$ & $\$ 2.32$ & $-6.9 \%$ & $-12.8 \%$ \\
\hline Warehouse & 17.1 & 14.7 & $\$ 0.40$ & $\$ 0.35$ & $13.9 \%$ & $12.4 \%$ \\
\hline Quick-Service Restaurant & 555.7 & 578.6 & $\$ 9.82$ & $\$ 10.27$ & $-4.1 \%$ & $-4.5 \%$ \\
\hline Full-Service Restaurant & 360.0 & 391.8 & $\$ 7.06$ & $\$ 7.85$ & $-8.8 \%$ & $-11.1 \%$ \\
\hline Mid-Rise Apartment & 43.5 & 42.3 & $\$ 1.25$ & $\$ 1.22$ & $2.8 \%$ & $2.7 \%$ \\
\hline High-Rise Apartment & 49.6 & 48.7 & $\$ 1.22$ & $\$ 1.20$ & $1.9 \%$ & $2.0 \%$ \\
\hline \multicolumn{7}{|l|}{ Totals } \\
\hline Climate Zone Weighted Average & 60.4 & 65.7 & $\$ 1.49$ & $\$ 1.63$ & $-8.6 \%$ & $-9.1 \%$ \\
\hline
\end{tabular}


Table D.9. Energy and Energy Cost Comparison for the 2012 IECC and 90.1-2010 - Climate Zone 4C Salem

\begin{tabular}{|c|c|c|c|c|c|c|}
\hline & $90.1-2010$ & 2012 IECC & $90.1-2010$ & 2012 IECC & & \\
\hline Prototype Name & $\begin{array}{c}\text { Site Energy } \\
{[\mathrm{kBtu} / \mathrm{sf}]}\end{array}$ & $\begin{array}{l}\text { Site Energy } \\
{[\mathrm{kBtu} / \mathrm{sf}]}\end{array}$ & $\begin{array}{l}\text { Site Energy Cost } \\
{[\$ / \mathrm{sf}]}\end{array}$ & $\begin{array}{l}\text { Site Energy Cost } \\
{[\$ / \mathrm{sf}]}\end{array}$ & $\begin{array}{l}\text { Site Energy } \\
\text { Savings }\end{array}$ & $\begin{array}{c}\text { Energy Cost } \\
\text { Savings }\end{array}$ \\
\hline Small Office & 27.9 & 28.0 & $\$ 0.84$ & $\$ 0.84$ & $-0.1 \%$ & $0.1 \%$ \\
\hline Medium Office & 31.4 & 36.5 & $\$ 0.89$ & $\$ 0.95$ & $-16.4 \%$ & $-6.7 \%$ \\
\hline Large Office & 66.1 & 72.7 & $\$ 1.93$ & $\$ 2.09$ & $-10.1 \%$ & $-8.1 \%$ \\
\hline Stand-Alone Retail & 51.0 & 50.9 & $\$ 1.24$ & $\$ 1.32$ & $0.3 \%$ & $-6.4 \%$ \\
\hline Strip Mall & 52.7 & 51.5 & $\$ 1.32$ & $\$ 1.31$ & $2.3 \%$ & $1.3 \%$ \\
\hline Primary School & 50.3 & 61.4 & $\$ 1.30$ & $\$ 1.47$ & $-22.0 \%$ & $-13.3 \%$ \\
\hline Secondary School & 40.1 & 44.7 & $\$ 1.07$ & $\$ 1.21$ & $-11.4 \%$ & $-13.6 \%$ \\
\hline Outpatient Healthcare & 110.2 & 136.5 & $\$ 2.79$ & $\$ 3.41$ & $-23.8 \%$ & $-22.4 \%$ \\
\hline Hospital & 121.0 & 160.2 & $\$ 2.82$ & $\$ 3.55$ & $-32.4 \%$ & $-25.9 \%$ \\
\hline Small Hotel & 59.7 & 62.5 & $\$ 1.32$ & $\$ 1.42$ & $-4.7 \%$ & $-7.0 \%$ \\
\hline Large Hotel & 92.9 & 97.1 & $\$ 1.90$ & $\$ 2.14$ & $-4.6 \%$ & $-12.7 \%$ \\
\hline Warehouse & 17.6 & 16.0 & $\$ 0.39$ & $\$ 0.35$ & $9.4 \%$ & $9.3 \%$ \\
\hline Quick-Service Restaurant & 575.6 & 599.7 & $\$ 9.73$ & $\$ 10.14$ & $-4.2 \%$ & $-4.3 \%$ \\
\hline Full-Service Restaurant & 376.4 & 399.0 & $\$ 6.99$ & $\$ 7.37$ & $-6.0 \%$ & $-5.4 \%$ \\
\hline Mid-Rise Apartment & 43.2 & 42.1 & $\$ 1.20$ & $\$ 1.17$ & $2.5 \%$ & $2.5 \%$ \\
\hline High-Rise Apartment & 48.0 & 46.9 & $\$ 1.11$ & $\$ 1.09$ & $2.1 \%$ & $2.2 \%$ \\
\hline \multicolumn{7}{|l|}{ Totals } \\
\hline Climate Zone Weighted Average & 54.0 & 58.3 & $\$ 1.32$ & $\$ 1.43$ & $-7.8 \%$ & $-8.1 \%$ \\
\hline
\end{tabular}


Table D.10. Energy and Energy Cost Comparison for the 2012 IECC and 90.1-2010 - Climate Zone 5A Chicago

\begin{tabular}{|c|c|c|c|c|c|c|}
\hline & $90.1-2010$ & 2012 IECC & $90.1-2010$ & 2012 IECC & & \\
\hline Prototype Name & $\begin{array}{l}\text { Site Energy } \\
{[\mathrm{kBtu} / \mathrm{sf}]}\end{array}$ & $\begin{array}{l}\text { Site Energy } \\
{[\mathrm{kBtu} / \mathrm{sf}]}\end{array}$ & $\begin{array}{c}\text { Site Energy Cost } \\
{[\$ / \mathrm{sf}]}\end{array}$ & $\begin{array}{c}\text { Site Energy Cost } \\
{[\$ / \mathrm{sf}]}\end{array}$ & $\begin{array}{c}\text { Site Energy } \\
\text { Savings }\end{array}$ & $\begin{array}{c}\text { Energy Cost } \\
\text { Savings }\end{array}$ \\
\hline Small Office & 30.6 & 30.9 & $\$ 0.90$ & $\$ 0.91$ & $-1.0 \%$ & $-0.3 \%$ \\
\hline Medium Office & 38.4 & 36.9 & $\$ 1.03$ & $\$ 1.02$ & $4.0 \%$ & $1.1 \%$ \\
\hline Large Office & 73.5 & 79.8 & $\$ 2.07$ & $\$ 2.21$ & $-8.5 \%$ & $-6.7 \%$ \\
\hline Stand-Alone Retail & 53.7 & 55.1 & $\$ 1.35$ & $\$ 1.46$ & $-2.6 \%$ & $-7.8 \%$ \\
\hline Strip Mall & 65.6 & 64.6 & $\$ 1.46$ & $\$ 1.48$ & $1.5 \%$ & $-1.2 \%$ \\
\hline Primary School & 56.3 & 68.0 & $\$ 1.39$ & $\$ 1.57$ & $-20.9 \%$ & $-13.0 \%$ \\
\hline Secondary School & 45.2 & 51.2 & $\$ 1.19$ & $\$ 1.35$ & $-13.3 \%$ & $-13.6 \%$ \\
\hline Outpatient Healthcare & 124.9 & 152.6 & $\$ 3.12$ & $\$ 3.76$ & $-22.1 \%$ & $-20.3 \%$ \\
\hline Hospital & 132.7 & 179.3 & $\$ 3.10$ & $\$ 3.88$ & $-35.1 \%$ & $-25.2 \%$ \\
\hline Small Hotel & 66.1 & 68.6 & $\$ 1.48$ & $\$ 1.57$ & $-3.8 \%$ & $-5.8 \%$ \\
\hline Large Hotel & 92.4 & 113.7 & $\$ 1.99$ & $\$ 2.40$ & $-23.0 \%$ & $-20.5 \%$ \\
\hline Warehouse & 24.3 & 19.3 & $\$ 0.46$ & $\$ 0.39$ & $20.6 \%$ & $15.6 \%$ \\
\hline Quick-Service Restaurant & 652.1 & 684.9 & $\$ 10.50$ & $\$ 11.17$ & $-5.0 \%$ & $-6.4 \%$ \\
\hline Full-Service Restaurant & 428.1 & 460.1 & $\$ 7.64$ & $\$ 8.13$ & $-7.5 \%$ & $-6.4 \%$ \\
\hline Mid-Rise Apartment & 52.0 & 50.7 & $\$ 1.31$ & $\$ 1.28$ & $2.5 \%$ & $2.5 \%$ \\
\hline High-Rise Apartment & 58.5 & 57.2 & $\$ 1.29$ & $\$ 1.26$ & $2.3 \%$ & $2.3 \%$ \\
\hline \multicolumn{7}{|l|}{ Totals } \\
\hline Climate Zone Weighted Average & 62.7 & 68.2 & $\$ 1.46$ & $\$ 1.59$ & $-8.6 \%$ & $-8.9 \%$ \\
\hline
\end{tabular}


Table D.11. Energy and Energy Cost Comparison for the 2012 IECC and 90.1-2010 - Climate Zone 5B Boise

\begin{tabular}{|c|c|c|c|c|c|c|}
\hline & 90.1-2010 & 2012 IECC & 90.1-2010 & 2012 IECC & & \\
\hline Prototype Name & $\begin{array}{c}\text { Site Energy } \\
{[\mathrm{kBtu} / \mathrm{sf}]}\end{array}$ & $\begin{array}{c}\text { Site Energy } \\
{[\mathrm{kBtu} / \mathrm{sf}]}\end{array}$ & $\begin{array}{c}\text { Site Energy Cost } \\
{[\$ / \mathrm{sf}]}\end{array}$ & $\begin{array}{c}\text { Site Energy Cost } \\
{[\$ / \mathrm{sf}]}\end{array}$ & $\begin{array}{l}\text { Site Energy } \\
\text { Savings }\end{array}$ & $\begin{array}{l}\text { Energy Cost } \\
\text { Savings }\end{array}$ \\
\hline Small Office & 29.4 & 29.5 & $\$ 0.88$ & $\$ 0.88$ & $-0.2 \%$ & $0.1 \%$ \\
\hline Medium Office & 34.1 & 37.9 & $\$ 0.95$ & $\$ 0.99$ & $-11.0 \%$ & $-4.7 \%$ \\
\hline Large Office & 72.7 & 77.5 & $\$ 2.11$ & $\$ 2.22$ & $-6.5 \%$ & $-5.6 \%$ \\
\hline Stand-Alone Retail & 56.7 & 56.5 & $\$ 1.36$ & $\$ 1.44$ & $0.3 \%$ & $-6.4 \%$ \\
\hline Strip Mall & 57.8 & 56.3 & $\$ 1.42$ & $\$ 1.40$ & $2.6 \%$ & $1.3 \%$ \\
\hline Primary School & 52.2 & 64.0 & $\$ 1.33$ & $\$ 1.53$ & $-22.7 \%$ & $-14.6 \%$ \\
\hline Secondary School & 43.7 & 49.2 & $\$ 1.15$ & $\$ 1.31$ & $-12.6 \%$ & $-14.4 \%$ \\
\hline Outpatient Healthcare & 116.9 & 143.2 & $\$ 3.04$ & $\$ 3.69$ & $-22.5 \%$ & $-21.4 \%$ \\
\hline Hospital & 131.3 & 174.6 & $\$ 3.14$ & $\$ 3.95$ & $-33.0 \%$ & $-25.9 \%$ \\
\hline Small Hotel & 62.3 & 65.0 & $\$ 1.39$ & $\$ 1.48$ & $-4.3 \%$ & $-6.4 \%$ \\
\hline Large Hotel & 100.1 & 108.3 & $\$ 2.03$ & $\$ 2.37$ & $-8.2 \%$ & $-16.4 \%$ \\
\hline Warehouse & 20.1 & 17.0 & $\$ 0.43$ & $\$ 0.37$ & $15.4 \%$ & $12.3 \%$ \\
\hline Quick-Service Restaurant & 611.3 & 638.1 & $\$ 10.23$ & $\$ 10.71$ & $-4.4 \%$ & $-4.7 \%$ \\
\hline Full-Service Restaurant & 395.6 & 431.0 & $\$ 7.30$ & $\$ 8.09$ & $-8.9 \%$ & $-10.8 \%$ \\
\hline Mid-Rise Apartment & 47.0 & 45.7 & $\$ 1.27$ & $\$ 1.23$ & $2.7 \%$ & $2.6 \%$ \\
\hline High-Rise Apartment & 52.1 & 51.0 & $\$ 1.21$ & $\$ 1.18$ & $2.3 \%$ & $2.3 \%$ \\
\hline \multicolumn{7}{|l|}{ Totals } \\
\hline Climate Zone Weighted Average & 59.8 & 65.0 & $\$ 1.43$ & $\$ 1.57$ & $-8.7 \%$ & $-9.5 \%$ \\
\hline
\end{tabular}


Table D.12. Energy and Energy Cost Comparison for the 2012 IECC and 90.1-2010 - Climate Zone 6A Burlington

\begin{tabular}{|c|c|c|c|c|c|c|}
\hline & $90.1-2010$ & 2012 IECC & $90.1-2010$ & 2012 IECC & & \\
\hline Prototype Name & $\begin{array}{l}\text { Site Energy } \\
{[\mathrm{kBtu} / \mathrm{sf}]}\end{array}$ & $\begin{array}{l}\text { Site Energy } \\
{[\mathrm{kBtu} / \mathrm{sf}]}\end{array}$ & $\begin{array}{c}\text { Site Energy Cost } \\
{[\$ / \mathrm{sf}]}\end{array}$ & $\begin{array}{c}\text { Site Energy Cost } \\
{[\$ / s f]}\end{array}$ & $\begin{array}{l}\text { Site Energy } \\
\text { Savings }\end{array}$ & $\begin{array}{l}\text { Energy Cost } \\
\text { Savings }\end{array}$ \\
\hline Small Office & 31.1 & 30.8 & $\$ 0.90$ & $\$ 0.89$ & $1.0 \%$ & $1.3 \%$ \\
\hline Medium Office & 40.9 & 37.3 & $\$ 1.06$ & $\$ 1.00$ & $8.8 \%$ & $5.5 \%$ \\
\hline Large Office & 75.5 & 80.3 & $\$ 2.07$ & $\$ 2.19$ & $-6.4 \%$ & $-5.6 \%$ \\
\hline Stand-Alone Retail & 55.7 & 55.6 & $\$ 1.36$ & $\$ 1.42$ & $0.2 \%$ & $-4.6 \%$ \\
\hline Strip Mall & 71.6 & 68.9 & $\$ 1.51$ & $\$ 1.48$ & $3.7 \%$ & $2.4 \%$ \\
\hline Primary School & 58.1 & 69.8 & $\$ 1.39$ & $\$ 1.55$ & $-20.1 \%$ & $-11.7 \%$ \\
\hline Secondary School & 45.6 & 51.2 & $\$ 1.16$ & $\$ 1.32$ & $-12.2 \%$ & $-13.8 \%$ \\
\hline Outpatient Healthcare & 129.7 & 154.8 & $\$ 3.16$ & $\$ 3.73$ & $-19.4 \%$ & $-18.0 \%$ \\
\hline Hospital & 140.8 & 192.2 & $\$ 3.16$ & $\$ 4.05$ & $-36.5 \%$ & $-28.2 \%$ \\
\hline Small Hotel & 68.8 & 70.3 & $\$ 1.53$ & $\$ 1.59$ & $-2.1 \%$ & $-3.6 \%$ \\
\hline Large Hotel & 93.3 & 117.8 & $\$ 1.96$ & $\$ 2.42$ & $-26.2 \%$ & $-23.5 \%$ \\
\hline Warehouse & 25.7 & 21.0 & $\$ 0.50$ & $\$ 0.41$ & $18.6 \%$ & $18.6 \%$ \\
\hline Quick-Service Restaurant & 697.2 & 732.5 & $\$ 10.82$ & $\$ 11.45$ & $-5.1 \%$ & $-5.8 \%$ \\
\hline Full-Service Restaurant & 459.3 & 494.0 & $\$ 7.84$ & $\$ 8.34$ & $-7.6 \%$ & $-6.4 \%$ \\
\hline Mid-Rise Apartment & 55.0 & 52.7 & $\$ 1.33$ & $\$ 1.29$ & $4.1 \%$ & $3.3 \%$ \\
\hline High-Rise Apartment & 61.0 & 58.5 & $\$ 1.29$ & $\$ 1.24$ & $4.2 \%$ & $3.9 \%$ \\
\hline \multicolumn{7}{|l|}{ Totals } \\
\hline Climate Zone Weighted Average & 70.0 & 76.6 & $\$ 1.60$ & $\$ 1.75$ & $-9.4 \%$ & $-9.1 \%$ \\
\hline
\end{tabular}


Table D.13. Energy and Energy Cost Comparison for the 2012 IECC and 90.1-2010 - Climate Zone 6B Helena

\begin{tabular}{|c|c|c|c|c|c|c|}
\hline & $90.1-2010$ & 2012 IECC & $90.1-2010$ & 2012 IECC & & \\
\hline Prototype Name & $\begin{array}{l}\text { Site Energy } \\
\text { [kBtu/sf] }\end{array}$ & $\begin{array}{l}\text { Site Energy } \\
{[\mathrm{kBtu} / \mathrm{sf}]}\end{array}$ & $\begin{array}{l}\text { Site Energy Cost } \\
{[\$ / \mathrm{sf}]}\end{array}$ & $\begin{array}{l}\text { Site Energy Cost } \\
{[\$ / \mathrm{sf}]}\end{array}$ & $\begin{array}{l}\text { Site Energy } \\
\text { Savings }\end{array}$ & $\begin{array}{c}\text { Energy Cost } \\
\text { Savings }\end{array}$ \\
\hline Small Office & 30.9 & 30.6 & $\$ 0.89$ & $\$ 0.88$ & $0.9 \%$ & $1.2 \%$ \\
\hline Medium Office & 37.4 & 40.2 & $\$ 0.99$ & $\$ 1.00$ & $-7.3 \%$ & $-0.4 \%$ \\
\hline Large Office & 74.9 & 79.1 & $\$ 2.11$ & $\$ 2.24$ & $-5.5 \%$ & $-6.2 \%$ \\
\hline Stand-Alone Retail & 61.7 & 53.9 & $\$ 1.40$ & $\$ 1.42$ & $12.6 \%$ & $-1.5 \%$ \\
\hline Strip Mall & 64.6 & 61.8 & $\$ 1.46$ & $\$ 1.42$ & $4.3 \%$ & $3.0 \%$ \\
\hline Primary School & 55.3 & 68.3 & $\$ 1.35$ & $\$ 1.54$ & $-23.4 \%$ & $-14.1 \%$ \\
\hline Secondary School & 44.7 & 50.3 & $\$ 1.13$ & $\$ 1.30$ & $-12.5 \%$ & $-14.9 \%$ \\
\hline Outpatient Healthcare & 122.9 & 152.8 & $\$ 3.13$ & $\$ 3.83$ & $-24.3 \%$ & $-22.5 \%$ \\
\hline Hospital & 138.2 & 188.7 & $\$ 3.18$ & $\$ 4.06$ & $-36.6 \%$ & $-27.9 \%$ \\
\hline Small Hotel & 65.7 & 67.4 & $\$ 1.45$ & $\$ 1.52$ & $-2.6 \%$ & $-4.2 \%$ \\
\hline Large Hotel & 91.3 & 113.4 & $\$ 1.92$ & $\$ 2.35$ & $-24.2 \%$ & $-22.3 \%$ \\
\hline Warehouse & 23.3 & 19.6 & $\$ 0.48$ & $\$ 0.40$ & $16.0 \%$ & $16.4 \%$ \\
\hline Quick-Service Restaurant & 660.5 & 690.1 & $\$ 10.59$ & $\$ 11.05$ & $-4.5 \%$ & $-4.4 \%$ \\
\hline Full-Service Restaurant & 429.0 & 462.3 & $\$ 7.56$ & $\$ 8.02$ & $-7.8 \%$ & $-6.1 \%$ \\
\hline Mid-Rise Apartment & 51.3 & 49.1 & $\$ 1.31$ & $\$ 1.26$ & $4.3 \%$ & $3.4 \%$ \\
\hline High-Rise Apartment & 56.2 & 53.9 & $\$ 1.24$ & $\$ 1.19$ & $4.2 \%$ & $3.9 \%$ \\
\hline \multicolumn{7}{|l|}{ Totals } \\
\hline Climate Zone Weighted Average & 67.0 & 73.5 & $\$ 1.54$ & $\$ 1.69$ & $-9.7 \%$ & $-10.3 \%$ \\
\hline
\end{tabular}


Table D.14. Energy and Energy Cost Comparison for the 2012 IECC and 90.1-2010 - Climate Zone 7 Duluth

\begin{tabular}{|c|c|c|c|c|c|c|}
\hline & $90.1-2010$ & 2012 IECC & $90.1-2010$ & 2012 IECC & & \\
\hline Prototype Name & $\begin{array}{l}\text { Site Energy } \\
{[\mathrm{kBtu} / \mathrm{sf}]}\end{array}$ & $\begin{array}{c}\text { Site Energy } \\
{[\mathrm{kBtu} / \mathrm{sf}]}\end{array}$ & $\begin{array}{c}\text { Site Energy Cost } \\
{[\$ / \mathrm{sf}]}\end{array}$ & $\begin{array}{c}\text { Site Energy Cost } \\
{[\$ / \mathrm{sf}]}\end{array}$ & $\begin{array}{c}\text { Site Energy } \\
\text { Savings }\end{array}$ & $\begin{array}{c}\text { Energy Cost } \\
\text { Savings }\end{array}$ \\
\hline Small Office & 34.2 & 33.8 & $\$ 0.93$ & $\$ 0.91$ & $1.3 \%$ & $2.0 \%$ \\
\hline Medium Office & 45.1 & 39.9 & $\$ 1.11$ & $\$ 1.03$ & $11.5 \%$ & $7.3 \%$ \\
\hline Large Office & 78.5 & 81.9 & $\$ 2.08$ & $\$ 2.18$ & $-4.3 \%$ & $-5.1 \%$ \\
\hline Stand-Alone Retail & 60.4 & 58.9 & $\$ 1.40$ & $\$ 1.46$ & $2.6 \%$ & $-4.5 \%$ \\
\hline Strip Mall & 80.9 & 76.9 & $\$ 1.60$ & $\$ 1.55$ & $4.9 \%$ & $3.2 \%$ \\
\hline Primary School & 64.9 & 74.4 & $\$ 1.43$ & $\$ 1.58$ & $-14.7 \%$ & $-10.3 \%$ \\
\hline Secondary School & 49.0 & 53.4 & $\$ 1.16$ & $\$ 1.30$ & $-8.8 \%$ & $-12.9 \%$ \\
\hline Outpatient Healthcare & 134.9 & 164.0 & $\$ 3.19$ & $\$ 3.82$ & $-21.6 \%$ & $-19.8 \%$ \\
\hline Hospital & 146.8 & 201.1 & $\$ 3.20$ & $\$ 4.08$ & $-37.0 \%$ & $-27.4 \%$ \\
\hline Small Hotel & 72.8 & 74.2 & $\$ 1.61$ & $\$ 1.66$ & $-2.0 \%$ & $-3.5 \%$ \\
\hline Large Hotel & 98.4 & 127.3 & $\$ 1.97$ & $\$ 2.46$ & $-29.3 \%$ & $-24.9 \%$ \\
\hline Warehouse & 34.3 & 27.8 & $\$ 0.59$ & $\$ 0.48$ & $19.1 \%$ & $19.0 \%$ \\
\hline Quick-Service Restaurant & 765.3 & 804.3 & $\$ 11.53$ & $\$ 12.05$ & $-5.1 \%$ & $-4.5 \%$ \\
\hline Full-Service Restaurant & 503.5 & 544.3 & $\$ 8.22$ & $\$ 8.76$ & $-8.1 \%$ & $-6.5 \%$ \\
\hline Mid-Rise Apartment & 59.8 & 56.5 & $\$ 1.38$ & $\$ 1.33$ & $5.6 \%$ & $3.6 \%$ \\
\hline High-Rise Apartment & 66.0 & 62.2 & $\$ 1.33$ & $\$ 1.28$ & $5.8 \%$ & $4.2 \%$ \\
\hline \multicolumn{7}{|l|}{ Totals } \\
\hline Climate Zone Weighted Average & 77.6 & 85.7 & $\$ 1.69$ & $\$ 1.86$ & $-10.5 \%$ & $-10.4 \%$ \\
\hline
\end{tabular}


Table D.15. Energy and Energy Cost Comparison for the 2012 IECC and 90.1-2010 - Climate Zone 8 Fairbanks

\begin{tabular}{|c|c|c|c|c|c|c|}
\hline & $90.1-2010$ & 2012 IECC & $90.1-2010$ & 2012 IECC & & \\
\hline Prototype Name & $\begin{array}{l}\text { Site Energy } \\
{[\mathrm{kBtu} / \mathrm{sf}]}\end{array}$ & $\begin{array}{l}\text { Site Energy } \\
{[\mathrm{kBtu} / \mathrm{sf}]}\end{array}$ & $\begin{array}{c}\text { Site Energy Cost } \\
{[\$ / \mathrm{sf}]}\end{array}$ & $\begin{array}{c}\text { Site Energy Cost } \\
{[\$ / \mathrm{sf}]}\end{array}$ & $\begin{array}{c}\text { Site Energy } \\
\text { Savings }\end{array}$ & $\begin{array}{c}\text { Energy Cost } \\
\text { Savings }\end{array}$ \\
\hline Small Office & 43.4 & 44.6 & $\$ 1.01$ & $\$ 1.02$ & $-2.7 \%$ & $-0.5 \%$ \\
\hline Medium Office & 61.3 & 54.2 & $\$ 1.39$ & $\$ 1.24$ & $11.6 \%$ & $10.6 \%$ \\
\hline Large Office & 91.2 & 93.2 & $\$ 2.20$ & $\$ 2.28$ & $-2.2 \%$ & $-3.5 \%$ \\
\hline Stand-Alone Retail & 85.6 & 79.9 & $\$ 1.69$ & $\$ 1.69$ & $6.7 \%$ & $-0.2 \%$ \\
\hline Strip Mall & 112.3 & 103.4 & $\$ 1.92$ & $\$ 1.84$ & $7.9 \%$ & $4.3 \%$ \\
\hline Primary School & 91.4 & 96.5 & $\$ 1.71$ & $\$ 1.79$ & $-5.6 \%$ & $-4.7 \%$ \\
\hline Secondary School & 75.2 & 75.5 & $\$ 1.43$ & $\$ 1.51$ & $-0.4 \%$ & $-5.8 \%$ \\
\hline Outpatient Healthcare & 165.1 & 210.1 & $\$ 3.63$ & $\$ 4.44$ & $-27.2 \%$ & $-22.5 \%$ \\
\hline Hospital & 167.6 & 231.5 & $\$ 3.42$ & $\$ 4.49$ & $-38.1 \%$ & $-31.3 \%$ \\
\hline Small Hotel & 85.3 & 85.3 & $\$ 1.88$ & $\$ 1.91$ & $-0.1 \%$ & $-1.2 \%$ \\
\hline Large Hotel & 130.5 & 173.8 & $\$ 2.29$ & $\$ 2.92$ & $-33.3 \%$ & $-27.8 \%$ \\
\hline Warehouse & 37.8 & 30.0 & $\$ 0.63$ & $\$ 0.51$ & $20.6 \%$ & $18.4 \%$ \\
\hline Quick-Service Restaurant & 947.6 & 997.9 & $\$ 13.26$ & $\$ 13.87$ & $-5.3 \%$ & $-4.6 \%$ \\
\hline Full-Service Restaurant & 629.6 & 684.9 & $\$ 9.42$ & $\$ 10.09$ & $-8.8 \%$ & $-7.1 \%$ \\
\hline Mid-Rise Apartment & 72.0 & 67.6 & $\$ 1.52$ & $\$ 1.47$ & $6.1 \%$ & $3.7 \%$ \\
\hline High-Rise Apartment & 77.5 & 73.0 & $\$ 1.49$ & $\$ 1.43$ & $5.8 \%$ & $4.4 \%$ \\
\hline \multicolumn{7}{|l|}{ Totals } \\
\hline Climate Zone Weighted Average & 88.4 & 92.3 & $\$ 1.73$ & $\$ 1.83$ & $-4.5 \%$ & $-5.9 \%$ \\
\hline
\end{tabular}




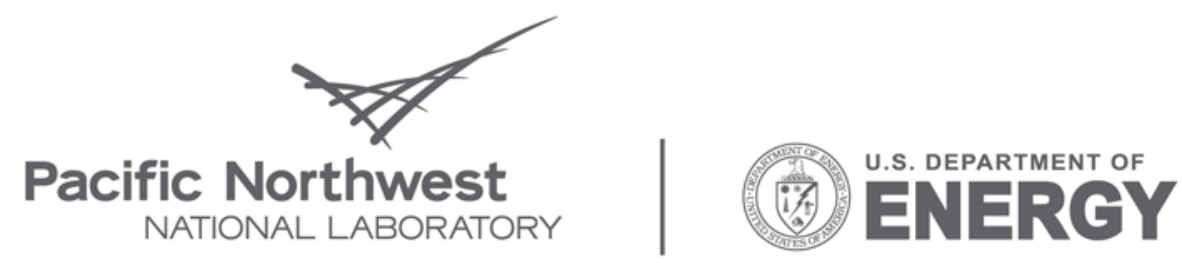

Proudly Operated by Battelle Since 1965

902 Battelle Boulevard

P.O. Box 999

Richland, WA 99352

1-888-375-PNNL (7665)

www.pnl.gov 